\title{
Automatisering en wetenschappelijk onderzoek in de huisartspraktijk : de mogelijkheden en merites van een nieuw instrument
}

Citation for published version (APA):

Höppener, P. (1990). Automatisering en wetenschappelijk onderzoek in de huisartspraktijk : de mogelijkheden en merites van een nieuw instrument. [Doctoral Thesis, Maastricht University]. Rijksuniversiteit Limburg. https://doi.org/10.26481/dis.19901122ph

Document status and date:

Published: 01/01/1990

DOI:

10.26481/dis.19901122ph

Document Version:

Publisher's PDF, also known as Version of record

Please check the document version of this publication:

- A submitted manuscript is the version of the article upon submission and before peer-review. There can be important differences between the submitted version and the official published version of record.

People interested in the research are advised to contact the author for the final version of the publication, or visit the DOI to the publisher's website.

- The final author version and the galley proof are versions of the publication after peer review.

- The final published version features the final layout of the paper including the volume, issue and page numbers.

Link to publication

\footnotetext{
General rights rights.

- You may freely distribute the URL identifying the publication in the public portal. please follow below link for the End User Agreement:

www.umlib.nl/taverne-license

Take down policy

If you believe that this document breaches copyright please contact us at:

repository@maastrichtuniversity.nl

providing details and we will investigate your claim.
}

Copyright and moral rights for the publications made accessible in the public portal are retained by the authors and/or other copyright owners and it is a condition of accessing publications that users recognise and abide by the legal requirements associated with these

- Users may download and print one copy of any publication from the public portal for the purpose of private study or research.

- You may not further distribute the material or use it for any profit-making activity or commercial gain

If the publication is distributed under the terms of Article $25 \mathrm{fa}$ of the Dutch Copyright Act, indicated by the "Taverne" license above, 
Omslag: Guus van Rooy (audiovisuele dienst RL), Menno Smidt. Cartoons/illustraties: Toon Hezemans, Wandana Höppener.

Lay-out: Meditekst, Lelystad. 


\title{
Automatisering en wetenschappelijk onderzoek in de huisartspraktijk
}

De mogelijkheden en merites van een nieuw instrument

\author{
Proefschrift
}

ter verkrijging van de graad wan doctor aan de

Rijksuniversiteit Limburg te Maastricht, op gezag van de Rector Magnificus, Prof. dr. F.I.M. Bonke, volgens het besiuit van het College van Dekanen, in het openbaar te verdedigen

op donderdag, 22 nowember 1990 om 16.00 uur

door

Paul Höppener

geboren te Roermond in 1937 


\section{Promotores}

Prof. dr. J.A.Knottnerus

Prof. dr. H.F.J.M. Crebolder

\section{Beoordelingscommissie}

Prof. dr. F. Sturmans (voorzitter)

Prof. dr. F.Th. Bosman

Prof. dr. J. van Eijk

Prof. dr. J.M. Greep

Dr. P. Pop

Het verschijnen van dit proefschrift is financieel mogelijk gemaakt door bijdragen van Smith Kline \& French B.V. te Rijswijk (Smith Kline Beecham) en

VVAA Nederlandse Vereniging Van Artsen te Utrecht. 

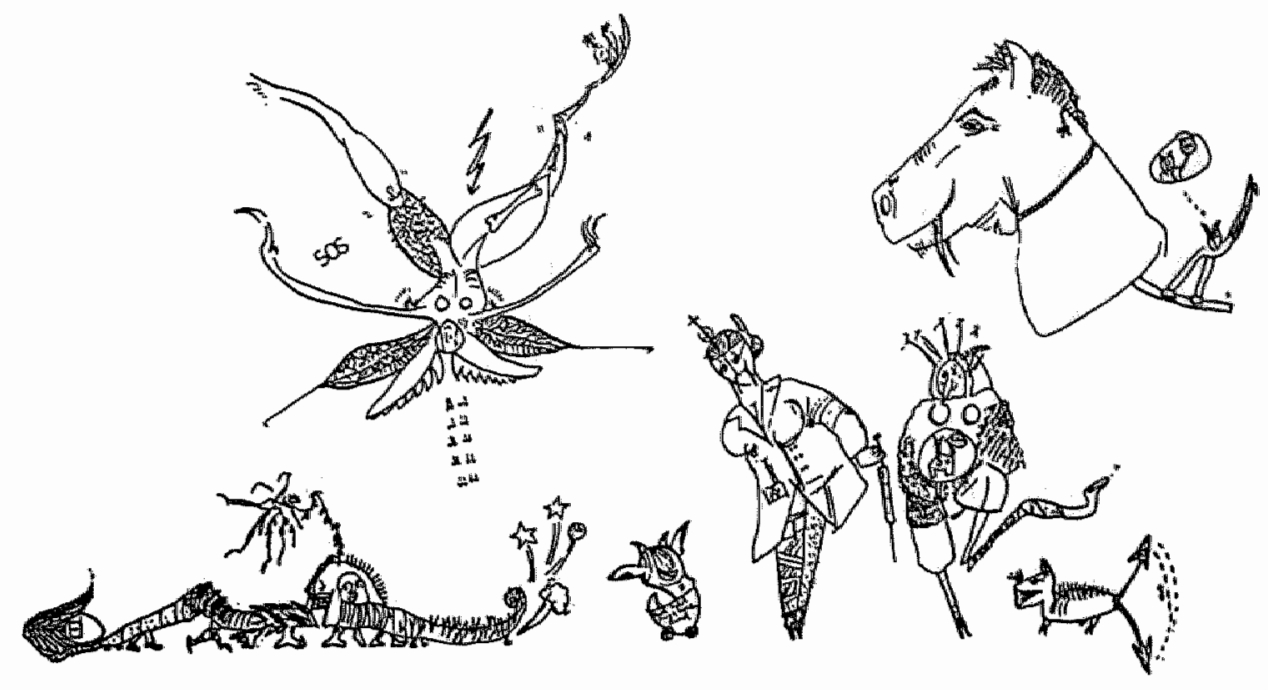

quatre filles et la mire sout cing diables pour le pire...

Q wandana Lecemile ' 83 .

Aan alle medewerkers van het RNH

Aux cinq diables pour le père 


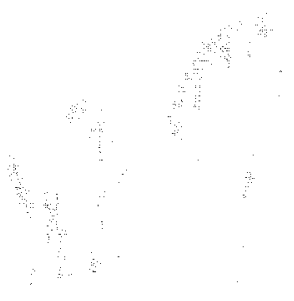

?
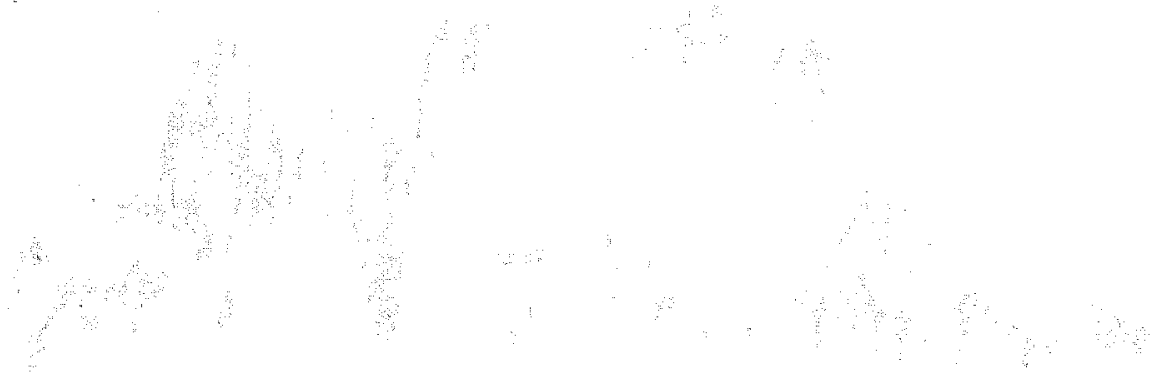

$\because \quad \therefore \quad \therefore$

$\therefore$

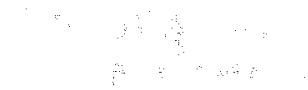


Dit proefschrift is het resultaat wan een lange periode waarin mijn werk als huisarts, het omgaan met gezonde en zieke mensen, werd gecombineerd en geïntegreerd met het werken met computers, die vaak ook wat mankeerden.

Reeds tijdens mijn tropenjaren (1964-1969) volgde ik met belangstelling de opmars van de computer en het toenemend gebruik ervan in de medische wereld. De komst van de microcomputer in 1978 maakte automatisering van de huisartspraktijk pas echt uitvoerbaar. Bij de verdere ontwikkelingen, zoals die zijn beschreven in hoofdstuk 2, ben ik nauw betrokken geweest. De kiem van dit proefschrift werd gelegd door Frank Guldemond en Geert Jan van Schendel, die mij in 1985 betrokken bij de oprichting van de gebruikersvereniging Orghis. In $1987 \mathrm{kwam}$ dank zij de stimulerende invloed van Ferd Sturmans een blijvend contact tot stand tussen het Registratienet Huisartspraktijken van de Rijksuniversiteit Limburg (RNH) en een aantal Orghis-praktijken uit de regio. Dit heeft in 1988 geleid tot een blijvende werkrelatie met de Vakgroep Huisartsgeneeskunde. André Knottnerus, projectleider van het RNH, heeft mij vóór die tijd al regelmatig aangeraden om de ervaringen van zoveel jaren in een proefschrift vast te leggen. Vanuit mijn functie als coördinator van het RNH had ik de mogelijkheid om verder onderzoek te verrichten betreffende de meerwaarde van de praktijkautomatisering bij huisartsgeneeskundig onderzoek.

Door de inzet en het enthousiasme van alle medewerkers van het RNH kon dit onderzoek uitgevoerd worden en verwerkt worden in dit proefschrift. Een groot team van huisartsen en praktijkmedewerkers, de staf en medewerkers van de Vakgroep Huisartsgeneeskunde heeft hier aan meegewerkt. Speciale vermelding komt toe aan: André Knottnerus, stimulerende en kritische promotor die dit twee jaar durende proces als een goede vroedmeester heeft begeleid; Harry Crebolder die als promotor de afronding en eindfase heeft ondersteund; Job Metsemakers die meewerkte aan het tot stand komen van het vierde hoofdstuk; Bep Köhlen, als researchassistente van het RNH een grote steun bij het in de hoofdstukken 3 en 6 beschreven onderzoek; Jim Tatipata(f) die de eerste secretariële ondersteuning gaf; en Frits Ruyters die tot aan het eindpunt hierbij was betrokken.

Dank gatat ook uit naar allen die meewerkten aan het onderzoek en de enquêtes van de hoofdstukken 3 en 4 en naar de mede-auteurs van hoofdstukken 5, 6,8 en 9. De diensten van het Medisch en Maatschappelijk Informatiecentrum van de Rijksuniversiteit Limburg (MEMIC) waren essentieel voor het tot stand komen van dit proefschrift; dank hiervoor aan Charles Limonard, Gregor Franssen en Jan Bergers. Het Integraal Kankercentrum Limburg (IKL) verzette in de persoon van Leo Schouten veel werk als partner bij het in hoofdstuk 8 beschreven onderzoek, Piet van de Brand verleende daarbij kritische ondersteuning. 
Waardering ook voor de leden wan de beoordelingscommissie, die met veel zorg in de valk warme dagen wlak vór of tijdens hun vakanties deze taak hebben wervuld.

De afwerking van deze dissertatie werd verzorgd door een aantal personen, die hier bedankt worden voor thun inzet. Ruud van der Helm keek kritisch naar het eerste concept van een antal hoofdstukken, Pieter Defesche controleerde en verbeterde de eindversie. Piet Klerkx verzorgde de Engelse vertaling van de samenvatting, Jan Hein Meddens leverde de Franse vertaling en Jan van Nimwegen nam de Duitse versie hiervan voor zijn rekening. De omslag werd ontworpen door Guus van Rooy (audiovisuele dienst RL), de pictogrammen op de omslag door Menno Smidi. Toon Hezemans (Via Media, Heerlen) zorgde woor de cartoons en mijn dochter Wandana maakte een bij de opdracht passende tekening:

Erik Hofmans (Meditekst, Lelystad) heeft veel aandacht besteed aan de definitieve vormgewing van dit proefschrift.

Het thuisfront heeft niet alleen mogelijk gemaakt dat er aan deze dissertatie werd gewerkt, maar heeft hier ook actief aan meegewerkt. Pia Cuypers heeft als praktijkassistente veel secretariẻle en morele ondersteuning gegeven, Jan Joost Rethans speelde een belangrijke rol bij de kritische beoordeling en uitvoering van het beschreven onderzoek. George Wolfs en later Margo van de Winkel namen als huisarts in opleiding veel werk uit handen op drukke momenten.

Quatre filles et la mère hebben met engelengeduld dit hele proces begeleid. 


\section{Inhoud}

$\begin{array}{ll}\text { Voorwoord } & 7\end{array}$

Gebruikte afkortingen $\quad$ II

1. Inleiding 13

2. De microcomputer in de huisartspraktijk 17

2.1. Inleiding 17

2.2. De beroepsverenigingen 19

2.3. De gebruikers: de huisartsen zelf 21

2.4. De industrie: de HIS-leveranciers 22

2.5. De universiteiten 22

2.6. De stand van zaken in 1990

2.7. Verwachtingen voor de toekomst 26

$\begin{array}{ll}\text { Literatuur } & 27\end{array}$

3. Automatisering in Huisarts en Wetenschap: een analyse van gepubliceerde $\begin{array}{lr}\text { onderzoekverslagen } & 29\end{array}$

3.1. Inleïding $\quad 29$

3.2. Methode 30

3.3. Resultaten 34

3.4. Beschouwing $\quad 42$

3.5. Conclusie 44

$\begin{array}{ll}\text { Literatuur } & 44\end{array}$

4. Huisartsgeneeskundige registratiesystemen 49

4.1. Inleiding 49

4.2. Methode 50

4.3. Nederlandse huisartsgeneeskundige registratiesystemen 50

4.4. Beschouwing en conclusie 55

Literatuur $\quad 56$

Bijlage 4.1. Morbiditeitsregistratie Netwerk Groningen (RNG) 57

5. Het geautomatiseerde steekproefbestand voor huisartsgeneeskundig onderzoek van de Rijksuniversiteit Limburg $\quad 59$

5.1. Inleiding 59

5.2. Registratienet Huisartspraktijken $\quad 59$

5.3. Registratie 60

5.4. Kwaliteitsbewaking 61

$\begin{array}{lll}\text { 5.5. Verzamelde data } & 62\end{array}$

5.6. Toepassingen $\quad 63$

$\begin{array}{ll}\text { Literatuur } & 65\end{array}$ 
6. Verslag van een automatiseringsproces 66

6.1. Overwegingen bij de keuze voor automatusering 66

6.2. Implementatie van de automatisering 67

6.3. Organisatie dataverzameling, -bewerking en -controle 70

6.4. Conclusie 75

Literatuur $\quad 75$

7. Het Registratienet Huisartspraktijken getest I 77

7.1. Inleiding 77

7.2. Methode 78

7.3. Resultaten 80

7.4. Beschouwing en conclusie $\quad 82$

Literatuiur $\quad 84$

8. Het Registratienet Huisartspraktijken getest II 85

8.1. Inleiding $\quad 85$

8.2. Patienten en methoden 86

8.3. Resultaten 90

8.4. Beschouwing en conclusies 94

$\begin{array}{ll}\text { Literatuur } & 98\end{array}$

9. De personal computer en de kwalliteit van de arts-patiënt relatie 99

9.1. Inleiding 99

9.2. Patiënten en methoden 100

9.3. Resultaten 101

$\begin{array}{ll}\text { 9.4. Beschouwing } & 102\end{array}$

$\begin{array}{ll}\text { Litteratuur } & 104\end{array}$

10. De bereikbaarheid van de "groene kaart" bij waarneming 105

10.1. Inleiding 105

10.2. Methode 107

10.3. Resultaten 108

10.4. Beschouwing en conclusie $\quad 108$

$\begin{array}{ll}\text { Literaturur } & 110\end{array}$

11. Beschouwing en conclusies 111

11.1. Huisarts en computer 111

11.2. Huisarts en wetenschap $\quad 112$

11.3. Huisarts, wetenscliap en computer $\quad 112$

11.4. Methodologische vragen 113

11.5. Patient en computer 114

11.6. Conclusies 115

Literatuur $\quad 118$

Sarmenvatting $\quad 119$

Summary $\quad 121$

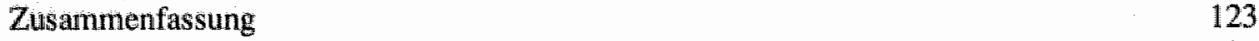

$\begin{array}{ll}\text { Resume } & 125\end{array}$

$\begin{array}{ll}\text { Appendix } & 127\end{array}$

$\begin{array}{ll}\text { Curriculum vitae } & 132\end{array}$ 


\section{Gebruikte afkortingen}

CCL Computer Centrum Limburg (inmiddels opgeheven)

CMR Continue Morbiditeits Registratie (project)

HAG Vakgroep Huisarts Geneeskunde

HIS Huisarts Informatie Systeem

HOS Huisarts Onderzoeksysteem

HIOS Huisartsen Informatie en Onderzoeksysteem (experimenteel)

ICPC International Classification of Primary Care

IOH Interfacultair Overleg Huisartsgeneeskunde

IOHOS Interfacultair Overleg Huisarts Onderzoek Systemen

KNMG Koninklijke Nederlandsche Maatschappij ter Bevordering van de Geneeskunst

LHV Landelijke Huisartsen vereniging

M(I)S Medische Informatica en Statistiek (vakgroep)

NHG Nederlands Huisartsen Genootschap

NHI Nederlands Huisartsen Instituut

PALGA Pathologisch Anatomisch Landelijk Geautomatiseerd Archief

PAOG Postacademisch Onderwijs Geneeskunde

RFE Reasons for Encounter (classificatie)

RIVOG Regionaal Informatievoorzieningssyteem Gezondheidszorg

SDM Stichting Dienstverlening Medici

STEN Stichting Educatie Nederland

VOH Vereniging voor Ondersteuning Huisartsen

WCIA Werkgroep Coördinatie Informatie Automatisering

WVC Ministerie van Welzijn, Volksgezondheid en Cultuur 
Van de unieke situatie in Nederland, dat de gegevens van een patient in het merendeel van de gevallen bij een huisarts terecht komen, zou meer gebruik kunnen worden gemaakt voor wetenschappelijk onderzoek, indien de kwaliteit van de huisartsregistratie zou kunnen worden vergroot. Stelling bij: Lee-Bijlsma A.van der. Analyse van evalluatieonderzoek bij bevolkingsonderzoek op cervixcarcinoom en relationele data-modellering. Proefschrift Erasmus Universiteit sept $87 /$ Swets en Zeitlinger 1987

'After all, data do not exist in nature, data are man made artefacts. What exists in the reality of nature are phenomena or entities that must be observed, described and catagorized to create data."

Feinstein, A.R. (1975) 


\section{Inleiding}

stethoscoop

telefoon:

anto

groene kaart...

computer?

Nieuwe technische en administratieve hulpmiddelen hebben de potentie om een schoksgewijze verbetering teweeg te brengen in de kwaliteit van het huisartsgeneeskundig handelen." Dit gebeurt alleen, wanneer ze binnen een korte periode worden geaccepteerd door een beroepsgroep, die snel overtuigd raakt van de voordelen die deze middelen bieden.

De microcomputer, bekrachtigd door goede huisartgeneeskundige software, heeft de potentie om zijn plaats in deze rij van vernieuwende verbeteringen waar te maken en een verbeterde versie te worden van de uit 1956 daterende 'Groene Kaart'. 2 De op het ogenblik beschikbare hardware en software vormen samen een nieuw instrument: een krachtig hulpmiddel voor de praktijkvoering van de huisarts, dat tevens reflectie op het eigen handelen (toetsing, kwaliteitsbewaking) kan bevorderen. Een huisarts zal alleen dản overgaan tot het gebruik van dit nieuwe instrument, de automatisering, wanneer hij overtuigd is van de meerwaarde hiervan.

In dit proefschrift wil ik, complementair aan de landelijk gevoerde "meerwaarde-discussie, ${ }^{34}$ onderzoeken welke argumenten er zijn voor de huisarts om gebruik te maken van een microcomputer en een Huisarts Informatie Systeem (HIS).

Sinds 1985 zijn er veel nieuwe ontwikkelingen geweest en is de automatisering van de huisarts in een versnelling geraakt. Het loont zeker om nog eens kritisch rond te kijken 'in het huis waarin de huisarts woont' en te onderzoeken of 'het plafond van 1985 de vloer van 1990 is geworden'.5

Het begrip "meerwaarde" dekt veel entiteiten: de mogelijke voordelen van praktijkautomatisering beginnen aan de onderkant bij applicaties voor de bedrijfskundige en financiele praktijkvoering en eindigen aan de bovenkant bij toepassingen voor wetenschappelijk onderzoek. De "meerwaarde' van de personal computer toegepast als factureer- en boekhoudmachine, met name in de apotheekhoudende huisartspraktijk, wordt hier niet verder ter discussie gesteld. Via een eenvoudige kosten/baten analyse kan iedere huisarts vaststellen of automatisering voor hem in dit opzicht 'meerwaarde' heeft of niet. In de praktijk is deze vraag al positief beantwoord" in Nederland en ook in het buitenland gebruiken zeer veel huisartsen de computer juist voor dit doel. ${ }^{6-10}$

Het concept van de probleemgeoriënteerde patiëntenkaart en van de probleemgeorièn- 
teerde "gezinsmap" is tot nu toe nog met weinig succes door het NHG en Universitaire Huisartsinstituten gepropageerd. 112 Naar mijn mening krijgt dit concept pas cen kans, wanneer de automatisering van de Nederiandse huisartspraktijken verder doorzet. De computer kan de huisarts ondersteunen bij het geordend vastleggen wan goed leesbare probleemlijsten en maakt het gebruik van een veetheid aan formulieren overbodig. Een praktijkcomputer die voorzien is van een goed Huisarts Informatie Systeem (HIS) maakt het praktisch uitvoerbaar om de inmiddels al vergrijzende "groene kaart' te vervangen en systematisch over te gaan tot probleemgeorienteerde medische verslaglegging. ${ }^{13}$

De aandrang om deze subjectieve mening te objectiveren is de motivatie voor het schrijven van dit proefschrift. Hierin wil ik de mogelijkheden van de automatisering, als instrument voor wetenschappelijk onderzoek in huisartspraktijken aangeven en kritisch bekijken. Tevens will ik een uitspraak doen ower de gevolgen die de acceptatie en integratie van de computer in de praktijkvoering zal hebben op de beroepsuitoefening van de huisarts.

Dit proefschrift biedt meer dan een afstandelijke registratie van historische feiten en nieuwe ontwikkelingen waarbij zeer veel personen en instellingen betrokken zijn geweest. Vanaf het begin (1979) ben ik actief betrokken bij de automatisering van de huisartspraktijk. Dit geldt ook voor het ontwikkelen van de beschreven organisatiestructuren en het ontwerpen van de beschreven onderzoekmethoden. De software-applicaties voor datacontrole, toetsing en datatransport zijn eigen werk.

In de volgende hoofdstukken worden onderzoekgegevens gerangschikt en toegelicht. Er wordt een beschrijving gegeven van de toegepaste onderzoekmethoden en de gebruikte organisatorische hulpmiddelen. Tevens worden de resultaten van explorerend en toetsend onderzoek vermeld. De vergaarde data zullen kritisch tegen het licht gehouden worden om te bekijken welke argumenten zijn aan te voeren voor of tegen de volgende stellingen:

- "Automatisering van de huisartspraktijk vergroot de mogelijkheden voor wetenschappelijk onderzoek en voegt daarmee een nieuwe dimensie toe aan het werk van de huisarts.'

- "De steeds verder voortschrijdende integratie van de computer in de huisartspraktijk zal de komende jaren de praktijkvoering efficienter maken en de kwaliteit van het werk van de huisarts verbeteren.'

Bij de opzet van dit proefschrift werd ik geinspireerd door een in de informatica vaak toegepaste modulaire programmeringstechniek, de zogenaamde Top-Down-benadering. Elk hoofdstuk heeft een eigen specifiek verhaal over de rol van de computer in de huisartsgeneeskunde en/of bij wetenschappelijk onderzoek. De hoofdstukken 2 tot en met 7 kunnen gelezen worden als een afzonderlijke module, zij vormen de basis ('down') voor de beschouwing en conclusies in hoofdstuk 8 en 9 , die worden ingeleid door dit hoofdstuk ("top").

In hoofdstuk 2 wordt de historische ontwikkeling van de automatisering van Nederlandse huisartspraktijken besproken.

In hoofdstuk 3 staan de resultaten van een literatuuranalyse. Daarbij is nagegaan in hoeverre de automatisering een rol speelt bij patièntgebonden huisartsgeneeskundig on- 


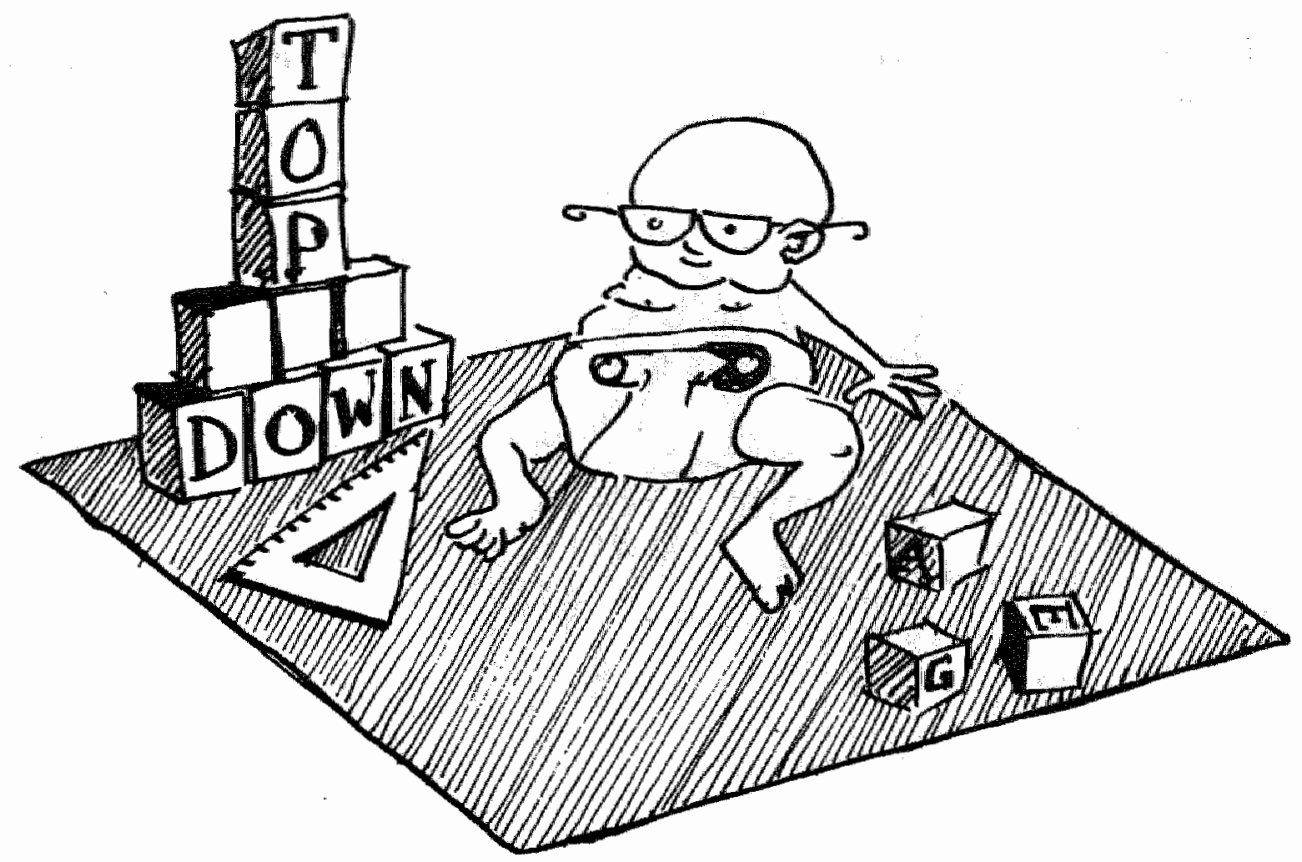

derzoek. De vooronderstelde meerwaarde van de automatisering in de verschillende onderzoeksituaties wordt besproken.

In hoofdstuk 4 wordt een overzicht gegeven van de in Nederland actieve huisartsgeneeskundige registratiesystemen. Met name wordt hierbij gekeken naar de rol die de computer momenteel speelt bij een aantal grote registratieprojecten.

In hoofdstuk 5 wordt ingegaan op de organisatie, werkwijze en resultaten van het Registratienet Huisartspraktijken van de Rijksuniversiteit Limburg (RNH). Het tweede deel van dit hoofdstuk behandelt de specifieke automatiseringsaspecten:

- de implementatie van de automatisering;

- de speciaal hiervoor ontwikkelde software-applicaties;"

- de bij toetsing en datatransport gebruikte procedures.

In hoofdstuk 6 wolgt een beschrijwing van twee onderzoekprojecten waarin gebruik wordt gemaakt van de door de RNH-praktijken geregistreende medische gegevens. Bij het eerste onderzoek wordt het accent gelegd op de ondersteuning die de automatisering biedt bij het uitwoeren van eenvoudig explorerend onderzoek met betrekking tot de kwaliteit van zorg in de huisartspraktijk.

Bij het tweede onderzoek wordt gekeken naar de betrouwbaarheid en volledigheid van de gegevens die door de huisartsen zijn vastgelegd in de computer.

In hoofdstuk 7 sluiten twee artikelen de rij: ze behandelen enkele vragen over de acceptatie van de praktijkcomputer door de patiënt. Ook wordt nader ingegaan op een belangrijk aspect wan de geautomatiseerde medische verslaglegging: de bescherming van de persoonlijke levenssfeer ("privacy") van de patiënt.

In hoofdstuk 8 wordt het verzamelde materiaal geèvalueerd en wordt nagegaan of or voldoende argumenten aanwezig zijn om de geformuleerde stellingen the bevestigen. Einkele methodologische aspecten van de geautomatiseerde dataverzameling in de huisartspraktijk en de gegevensopslag in een centraal computerbestand zullen worden besproken. 
Er wordit een overzicht gegeven van voor de hand liggende toepassingen van deze databestanden.

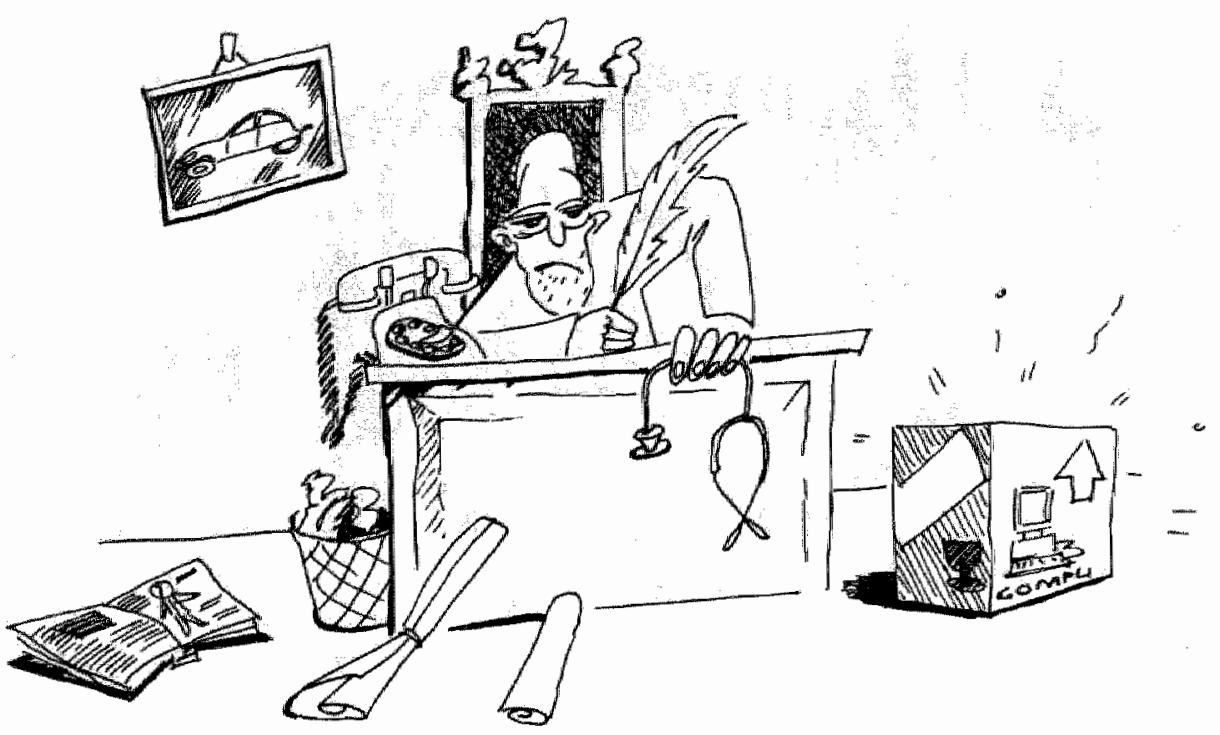

Bezint eer ge begint

\section{Literatuur}

1 Sietsma E. De telefoon in de huisartspraktijk. Proefschrift. Groningen: Rijksuniversiteit Groningen, 1987.

2 Meyboom WA. Inleiding tot de probleemgeoriénteerde registratiekaart. Huisarts Wet 1979; 22: 4-5.

3 Meyboom-de Jong B. Wat levert de computer op ? Huisarts Wet 1986; 29:363-4.

4 Voort JPM. van der. De invoering van automatisering nader onderzocht. Huisarts Wet 1988; $31: 114-5$.

5 Lamberts $H$. Het huis van de huisarts, nu en straks. Huisarts Wet 1986; 29:363-4.

6 LHV-Symposium. De geautomatiseerde huisarts in het Dekker tijdperk. Ede, 1989.

7 Staven K, Ostbye T. EDB for primaerleger. Status og utvikling. (Computer systems for general practitioners. Status and development). Tidsskr Nor Laegeforen. 1989; 109: $700-3$.

8 MeCray HE. Practice computerization: hints and suggestions. Md Med J 1989; 38: 77-9.

9 Schmittling GT. Computer use by family physicians in the United States. J.Fam Pract. 1989; 29: 198-200.

10 Daniels E, Coulter A. How to choose a general practice computing system: comparison of commercial packages. Br Med J 1988; 297: 838-40.

11. Themanummer Huisarts en Wetenschap 1979, no I.

12 Horst van der F, Vierhout W, Stallenhoef P. Probleemgeoriënteerde verslaglegging in de huisartspraktijk. Deel 1. Ervaringen. Huisarts Wet 1981;24:252-8.

13 Nederlands Huisartsen Genootschap. Medische Verslaglegging. Standaard. Huisarts Wet 1990; 33: 114-7. 


\section{De microcomputer in de huisartspraktijk}

Samenvatting Het is alweer meer dan 10 jaar geleden, dat de eerste microcomputers werden geîntroduceerd in de Nederlandse huisartspraktijk. De automatisering van de huisartspraktijken is in 1989 pas echt op gang gekomen; een goed moment dus om de balans op te maken. Dit hoofdstuk geeft een owerzicht van de korte geschiedenis van de automatisering van de huisartspraktijken in Nederland, de huidige stand van zaken en de verwachtingen woor de jaren negentig. De auteur is vanaf het begin betrokken geweest bij deze ontwikkelingen en heeft hier valk op intensieve wijze aan deelgenomen.

\subsection{Inleiding}

"Wie almaar denkt dat hij bezig is het buskruit uit te vinden, schiet op den duw in zijn eigen voet"

(Carlo Ginzburg, in 'De Tijd', juni 1989)

Het is al weer meer dan 10 jaar geleden dat de eerste Nederlandse huisartsen-pioniers de microcomputer binnenhaalden in hun praktijk en elkaar vonden in de werkgroep 'Huisarts en computer'. De automatisering van de Nederlandse huisartspraktijk is echter slechts zeer langzaam op gang gekomen. ${ }^{12}$ Pas sinds kort is er een doorbraak naar een versnelde en wijd verbreide invoering van de computer in de dagelijkse praktijkvoering. Eenzelfde ontwikkeling ziet men in het buitenland. ${ }^{3-8}$ Verwonderlijk is dit niet, alangezien automatisering en computergebruik snel toenemen in alle geledingen van de maatschappij.

Het Nederlands Huisartsen Genootschap (NHG) - en later ook de Landelijke Huisartsen vereniging ( $\mathrm{LHV}$ ) - hebben een goede basis gelegd voor de automatisering van de huisartspraktijk in Nederland. Het is nu een goed tijdstip voor een een beschrijving van de huidige stand van zaken, voor een momentopname. We staan thans op de drempel van nieuwe toepassingen van computers, ook in de huisartspraktijk. De functie en het functioneren van de huisarts zullen hierdoor waarschijnlijk wezenlijk veranderen in de komende 10 jaar. De computer zal niet alleen een efficiëntere praktijkworing mogelijk maken, maar zal ook steeds vaker ingeschakeld worden voor nascholing, kwahtiteitsbewaking en beslissingsondersteuning. Ook denken we hierbij aar de geautomatiseerde communicatie met apotheek en ziekenhuis en aan het meewerken van huisartsen aan de opbouw van dataverzamelingen voor wetenschappelijk onderzoek.

Op de pagina's 18 en 19 is een indeling gemaakt in twee periodes: een startperiode van 1979 tot 1984 en een tijdperk van groei naar volwassenheid. De nu volgende bespreking volgt de lijnen van de vaak onderling samenhangende en parallel verlopende ontwikkelingen bij de beroepsverenigingen, de huisartsen zelf, de industrie en de universiteiten. 
De geschiedenis van de computer in de huisartspraktijk

\section{Prehistorie}

1951 De eerste commerciêle computer wordt in gebruik genomen: de UNIVAC 1.

1959 De nogi steeds veel toegepaste computertaal COBOL ziet het licht.

1960 Begin van de planaire technologie: het 'stenen tijdperk' vangt aan (Silicium-geintegreerde circuits).

1962 IBM introduceent het eerste schijfgeheugen.

1963 Dprichting Stichting Medische Registratie met als doel geautomatiseerde bewerking van medische gegevens uit de ziekenhuizen voor epidemiologische doeleinden.

1965 Eerste aarzelend begin van de kantoor-en ziekenhuisautomatisering.

1976 De eerste commercieel verkrijgbare microcomputers verschijnen op de Amerikaanse markt, onder andere: PET (Commodore), de Apple en de TRS-80.

1978 De Amerikaanse microcomputers zijn ook in Nederland verkrijgbaar.

Periode 1 - Introductie van de microcomputer bij de huisarts

Tijdperk van de oprechte amateurs en professionele zoekers

1978 De eerste praktijkcomputers vinden hun huisarts.

1979 De werkgroep praktijkvoering van het NHG richt samen met het NHI de werkgroep 'Huisarts en computer' op.

Start van het Monitoringproject van Lamberts c.s.

1980 Workshop Automatisering van NHI en NHG in Utrecht.

De Hoytema cursus "automatisering", de eerste van een lange reeks nascholingscursussen over dit onderwerp.

1981 Publicatie van het Interim NHI-rapport 'Automatisering in de Huisartspraktijk' als aanzet voor verder onderzoek door het NHI.

1982 Toenemende activiteiten van individuele huisartsen op automatiseringsgebied (Manders, Zwaan, Botman).

Voortijdige beeindiging van het NHI-project, dat overgenomen wordt door het RIVOG.

1983 Start van het één jaar durende RIVOG-HIS project.

Ongeveer 35 huisartsen $(0,6 \%)$ maken bij de praktijkvoering gebruik van een computer.

Periode 2 - De ontwikkeling van de eerste generatie professionele

Nederlandse Huisarts Informatie Systemen (HIS) en introductie hiervan

in de praktijk

1984 Het RIVOG-HIS rapport verschijnt.

Oprichting van de WCIA door NHG en LHV en erkenning van deze werkgroep door het Ministerie van WVC.

Publicatie door WCIA van minimum-eisen waaraan HIS moet voldoen. Hearings voor de software-industrie.

Oprichting Medimatica en MD-TV: telecommunicatie voor de arts.

KNMG congres in Heerlen, waarbij telecommunicatie en automatisering de hoofthema's zijn. 
1985 Introductie van het ICPC code-systeem in Nederland.

NHG-congres in Rhenen o.a. over automatisering in de huisartspraktijk.

Oprichting en presentatie van de eerste HIS-gebruikers vereniging $10 \mathrm{rg}$ his).

1986 NUT-project van het NHG wordt gestart.

KNMG en LHV richten de Stichting Dienstverlening Medici (SOM) op, die onder meer tot doel heeft huisartsen te adviseren bij de automatisering.

De WCIA keurt de eerste 2 HIS-paketten.

1987 De LHV publiceert de "Nota Automatisering".

De VOH's gaan ook een rol spelen bij de locale begeleiding van de praktijkautomatisering.

Waarneemgroepen gaan op enkele plaatsen gezamenlijk automatiseren (Apeldoorn).

De LHV trekt zich terug uit SDM en komt met het NHG tot afspraken over de onderlinge taakverdeling bij het sturen en begeleiden van de huisartsen-automatisering. Het NHG start met de zogenaamde "STEN" cursussen: automatiseringseducatie waarop 700 huisartsen inschrijven.

Erkenning van de eerste gebruikersvereniging door de LHV.

1988 - De automatisering van de huisartpraktijk komt op gang: eind 1988 ge bruikt $20 \%$ van alle huisartsen een computer in de praktijk.

Intentieverklaring van LHV en NHG: de taken wat betreft de begeleiding en ontwikkeling van de huisartsenautomatisering worden afgebakend en verdeeld.

\subsection{De beroepsverenigingen}

In 1979 werden het Nederlands Huisartsen Instituut (NHI) en het Nederlands Huisartsen Genootschap (NHG) al snel door enkele vooruitziende medewerkers geattendeerd op de mogelijkheden, die de nietwe microcomputers hadden te bieden. De werkgroep 'Huisarts en Computer" werd opgericht. Een aantal pioniers, geïnteresseerden van het eerste uur, meldden zich al spoedig aan als lid. De werkgroep stimuleerde het N.H tot het opzenten van het project "Automatisering in de Huisartspraktijk".

Dit project had als doelstelling 'de planmatige en fasegewijze invoering van een geautomatiseerd Huisarts Informatie Systeem' (HIS). Er werd intensief gebrainstormd; de eerste fase van dit onderzoek, onder leiding van Ir. J. de Moel, liep tot october 1981 en werd afgerond met een rapportage. De plannen om dit project voort te zetten tot 1985 liepen spaak, toen de wetenschappelijke afdeling van het NHI in 1982 geleidelijk de aandacht verlegde naar de 'zachte sector'. Men was niet meer geïnteresseerd in software voor huisartsen. Zowel financiële als ideejle motieven speelden daarbij een rol.

Gelukkig was er op dat moment een gegadigde, die dit project over wilde nemen: het Regionaal Informatievoorzieningssysteem Gezondheidszorg (RIVOG), dat werd gesubsidieerd door het ministerie van WVC en de provincie Limburg. Het NHI, en ook de werkgroep 'Huisarts en Computer", maakten de leider van dit project, Ir. F: Krtutzen, attent op het reeds werrichte voorwerk. Op deze basis werd in 1983 het "RIVOG-HIS' project gestart. Dit éên jaar durende proef-project werd uitgevoerd door het Computer Centrum 
Limburg (CCL) in Heelen. ${ }^{10}$ Doelstelling was: het formuleren van de functionele en technische specificaties wataan cen Huisars Informatie Systeem (HIS) zou moeten voldoen.

Een klein aantal huisartsen - onder wie de auteur - werd hierbij betrokken in de fase van de systemanalyse en de ontwikkeling van prototypes. Een veel groter aantal werkte mee aan het testen van deze prototypes in de praktijk. De Rijksuniwersiteit Limburg participeerde actief in deze ontwerpfase via het Basisproject Verslaglegging en Registratie. "I.

Toen hel RIVOG-HIS project in december 1983 was afgerond, werd nog voordat de RIVOG-rapportage de deur uit was, de rode draad weer opgenomen door het NHG. ${ }^{12}$ In overleg met de LHV werd in 1984 de Werkgroep Coordinatie Informatie Automatisering (WCLA) opgericht. ${ }^{3}$ De voorzitter van deze werkgroep, de huisarts P. Cromme, gaf destijds de volgende motivatie: 'De vloedgolf van de automatisering overspoelt ook de geneeskundige beroepsbeoefenaren. We zijn nu nog net op tijd om een en ander centraal bij te sturen en te coördineren.'

Inderdaad: net op tijd om met goedkeuring van het ministerie van WVC de RIVOGHIS boedel over te nemen, waardoor deze werkgroep van meet af aan voldoende status en deskundigheid in huis had om zijn taak waar te kunnen maken. De voorspelde vloedgolf liet nog even op zich wachten.

De WCIA stelde zich tot doel:

1 Het invoeren van een pakket minimum-eisen waaraan HIS-programmatuur zou moeten voldoen. Dit zogenaamde 'Referentiemodel' was geënt op de RIVOG-HIS specificaties die in december 1983 al waren gedefiniëerd (rapportage gereed in october 1984). ${ }^{14}$

2 Het invoeren van een toetsprocedure voor commerciële HIS-pakketten (eerste toets atgustus 1986, eerste rapportage een jaar later).

3 Het uitvoeren van onderzoek. Gestart werd met het NUTI-project: een onderzoek van de implementatie van automatisering in 4 praktijken met als speciaal aandachtspunt het "nut' van de automatisering. (subsidie WVC 1985, NUT-rapportage 1986). ${ }^{\text {s. }}$

4 Het uitvoeren van een kennis- en deskundigheidsbevorderend programma. In 1987 werden in dit kader door de Stichting Educatie Nederland door het hele land de zogenaamde STEN-cursussen gegeven.

Door het werk van de WCIA - vooral een verdienste van het NHG - heeft in Nederland de automatisering van de huisartspraktijken een veel beter gereguleerd beloop gehad dan de automatisering bij de medische specialisten en de apothekers. Een dergelijke ordening en/of bijsturing is in de omringende landen niet tot stand gekomen. De in 1984 door de WCIA geformuleerde doelstellingen zijn grotendeels bereikt, zij het met een wat langzaam rijdende en logge trein. De keerzijde van de medaille was, dat een aantal initiatieven van automatiserende huisartsen die sneller wilden automatiseren of eigen ideeën hadden, werd afgeremd en soms zelfs geblokkeerd.

KNMG en LHV, de laatste via een bestuurslid vertegenwoordigd in de WCIA, kregen in 1986 meer vragen over automatisering op hun bord dan ze konden beantwoorden. Ze huisden toen nog gezamenlijk onder éen dak en vonden elkaar in een nieuw initiatief, dat meer actieve inbreng op het automatiseringsfront mogelijk moest maken. Dit was de in 1986 opgerichte Stichting Dienstverlening Medici (SDM). ${ }^{16}$ Leden, huisartsen die de grote stap naar de automatisering wilden zetten, konden hier terecht voor een aankoopadvies en de aanschaf (met $15 \%$ korting) van een computer + HIS. 
In feite doorkruiste dit initiatief het sturende en normerende beleid van WCIA en NHC: tijdelijk dreven er donkere wolken aan het zwerk. De meeste huisartsen waren echter, in tegenstelling tot wat voorspeld was, in 1986 nog niet rip voor automatisering. De bui dreef ower.

Pas in 1987, toen ook enkele van de pas opgerichte Verengingen voor Ondersteuning van Huisartsen ( $\mathrm{YOH}$ ) actief werden in het geven van automatiseringsadviezen, keerde de LHV terug op het ingeslagen pad en ging een gesprek aan met het NHG over een duidelijke taakverdeling bij het sturen en begeleiden van de automatiserende huisarts. Bij de intentieverklaring van NHG en LHV op 8 juli 1988 werd een aantal werkafspraken vastgelegd, die ook nu nog goed blijken te functioneren. Het NHG zou zich vooral bezighoum den met de inhoudelijke kanten van de automatisering, de LHV met de bellangenbehartiging van de automatiserende leden. De taken zijn als volgt verdeeld:

\section{Het NHG draagt zorg voor:}

- toetsing van Huisarts Informatie Systemen (WCIA).

- bijstellen van toetsingseisen = referentiemodel (WCIA).

- het samenstellen van een handleiding automatisering.

- het mede verder ontwikkelen, vaststellen en bewaken van een standaard voor het coderen.

- het definièren van een standaard "verslaglegging".

\section{De LHV richt zich op:}

- het onderhouden van een centraal informatiepunt 'automatisering'.

- ondersteuning van de erkende gebruikersverenigingen.

- het afsluiten van 'mantelovereenkomsten' met leveranciers van als 'voldoende" getoetste Huisarts Informatie Systemen.

- het creëren van gunstige secundaire voorwaanden via onderhandelingen met overheden en financiers.

- advisering van de automatiserende leden via de Verenigingen voor Ondersteuning van Huisartsen (de VOH's).

\subsection{De gebruikers: de huisartsen zelf}

De komst van de microcomputer in 1978 was een doorbraak: de eigen praktijkcomputer kwam binnen het bereik van de huisarts. Tot 1979 was er - voor zover dit is na te gatn slechts ến huisarts in het land die zijn oog op de computer had laten vallen (De Koning). ${ }^{17}$

In november 1980 vond de eerste 'gebruikersbijeenkomst' plaats in een barokke, voormalige kapel naast het toenmalige Nederlands Huisartsen Instituut. Het leek wel het begin van een nieuwe religie: de computers waren uitgestald op de altaren. Bij deze "workshop automatisering' van NHG en NHI waren naast de eerste huisartsen-pioniers ook vertegenwoordigers van de industrie (Philips), wan een ziekenfondsorganisatie, en van de Nederlandse Kruiswerenigingen aanwezig. Veel praktische resultaten leverde deze bijeenkomst niet op, wel werd de kiem voor latere samenwerking gelegd. 
De automatisering wan husartspraktijken wis het hobbyisme nog niet ontgroeid en voorlopig bleef dal $20^{18}$ het was een tijdperk van oprechte amateurs (Manders) ${ }^{19}$ en professionele zoekers (Botman, Zwaan) 202

De resultaten van het RIVOG-HIS project ${ }^{10}$ en de oprichting van de Werkgroep Coördinatie Informatie Automatisering van het $\mathrm{NHG}^{13}$ in 1984 brachten hier verandering in. De eerste generatie professionele Huisarts Informatie Systemen (HIS) kwam op de markt. Veel van de automatiseerders yan het eerste uur en tevens een aantal huisartsen die enkele jaren de kat uit de boom hadden gekeken, gingen nu over tot praktijkautomatisening met een HIS.

In 1985 werd de eerste gebrikersvereniging "Orghis" opgericht: een vereniging van en voor huisartsen die allen gebruik maakten van hetzelfde HIS. ${ }^{22}$ De stimulerende inwloed van de $\mathrm{LHV}$, die dît zag als éen van de hoekstenen van haar automatiseringsbeleid, leidde ertoe dat wanaf 1988 rondom elk HIS dergelijke gebruikersgroepen werden geformeerd. ${ }^{23}$

\subsection{De industrie: de HIS-leveranciers}

Reeds in $1979 \mathrm{kwam}$ het eerste commercièle software-programma voor huisartsen op de markt: ến van de vele pakketten die er vooral op gericht waren om de financiële administratie van (apotheekhoudende) huisartsen te verlichten.

Veel huisartsensoftware van het eerste uur is inmiddels weer van de markt verdwenen (tabellen 2.1-2.3). De ommekeer kwam toen de WCIA in 1984 enkele 'hearings' organiseerde, walar de industrie duidelijk te horen kreeg aan welke specificaties Huisarts Informatie Systemen voortaan zouden moeten voldoen. ${ }^{24}$ Alleen HIS-pakketten, die na een functionele en technische toetsing door de WCIA als "voldoende' werden beoordeeld zouden voortaan door het NHG worden aanbevolen.

Bij deze bijeenkomsten waren 30 vertegenwoordigers van commerciële ondernemingen aanwezig: slechts 5 daarvan hebben inmiddels een HIS op de markt gebracht dat voldoet aan de specificaties van de WCIA (tabel 2.1).

\subsection{De universiteilten}

Vanaf 1983 zijn de universiteiten direct betrokken bij de automatisering van huisartspraktijken: de afdeling Medische Informatica van de Vrije Universiteit (ontwikkeling Elias-HIS) en : de vakgroep Huisartsgeneeskunde van de Rijkstniversiteit Limburg (RIVOG-HIS project) liepen daarbij voorop.

In 1985 werd door het Interuniversitair Overleg Huisartsgeneeskunde (IOH) een werkgroep 'Classificatie en Codering' opgericht. ${ }^{25}$ Later werd ook het Interuniversitair Overleg Huisarts Onderzoek Systemen (IOHOS) opgericht door een aantal op automatiseringsgebied actieve huisartsgeneeskundige vakgroepen (HAG) en vakgroepen Medische Informatica en Statistiek (MI/S). Beide subgroepen, HAG en MI/S, worden hieronder afzonderlijk besproken. Hun specifieke automatiseringsactiviteiten over de periode 1979-1988 worden verder toegelicht:

- HAG Universiteit van Amsterdam. Sinds de komst van Prof. Dr. H. Lamberts in 1984 
Tabel 2.1 Getoetste Huisarts Informane Systemen (peildatum: I-I-1990)

DECLAMED ${ }^{4429}$

Toetsing: october 1986, augustus 1989

Beoordeelde modules: basis, medisch

- Softwarehuis: de Cleyenburg BV

micraHIS $^{44}$

Toetsing: oktober 1986

Beoordeelde modules: basis, medisch, apotheek

- Softwarehuis: WVAA Praktijkautomatisering Utrecht $^{-}$

ELIAS $^{31}$

Toetsing: juni 1988

Beoordeelde modules: basis, medisch

- Softwarehuis CENDATA BV

PROMEDICO 45

Toetsing: juli 1988

Beoordeellde modules: basis, apotheok

Softwarehuis: ACS, Sleeuwijk

PRACTISYYS ${ }^{46}$

Toetsing: oktober 1988

Beoordeelde module: apotheek

- Softwarehuis: Centraal Beheer Automatisering, Zeist

AMICE versie $\mathrm{F}^{47}$

Toetsing: november/december 1988

Beoordeelde modules: basis, medisch

- Softwarehuis: Grote Beer Sterprogramma's Delft.

SIGMA.PC ${ }^{27}$

Toetsing: juni 1989

Beoordeelde modules: basis, apotheek

Softwarehuis: Delft Automatisering, Delft

- betekent: aanwezig bij eerste hearing WCIA.

zijn de activiteiten hier geconcentreerd rondom het gebruik, de vertaling, de interpretatie en de conversie van de International Classification of Primary Care (ICPC), waarvan hij de geestelijke vader was. ${ }^{26}$ Een andere belangrijke activiteit is het sturen en begeleiden van het Transitieproject (zie ook hoofdstuk 4)

- HAG Rijksumiversiteit Leiden. Vanaf 1985 is hier gewerkt aan de ontwikkeling en het uittesten van een HIS (SIGMA P.C.) in samenwerking met het systeemhuis 'Delft Automatisering: ${ }^{27}$ In 1987 werd in samenwerking met de Universiteit van Amsterdam een project gestart om te komen tot een goede Nederlandse vertaling van de ICPC, een zoekwoordenlijst (thesaurus) en een synoniemenlijst. De Nederlandse vertaling van de Engelse 'short titles' van de ICPC is inmiddels klaar. Wetenschappelijke onderzoekers kunnen 
Tabel 2.2 overzicht van de op 1-7-1987 beschikbare softhate-pakketten voor huisartsen mer per paklket de gebruiksmogelijkheden en het adnal gebruikers per pakket.

\begin{tabular}{|c|c|c|c|c|c|}
\hline Soltwaropalkket & Bedrifif & Start & Verkocht" & Modules - & WCIA \\
\hline Aallu & Baars & 1987 & $C$ & 8 & - \\
\hline Amice & BMS & 1986 & $c$ & B. $M$ & - \\
\hline Commomedicai & RBK-data & 1984 & $\mathrm{~A}$ & $B$ & - \\
\hline Declamed & de Cleyenburgh & 1985 & A & $\mathrm{B}^{\prime}, \mathbf{M}$ & $+1-$ \\
\hline Declamed-MSX & de Clevenburg & 1986 & A & B & - \\
\hline Decspeed & v.Geijswijk & 1985 & $A$ & $\mathrm{~B}$ & - \\
\hline Dokprogramma & Compasji & 1981 & $c$ & $\mathrm{~B}$ & - \\
\hline DVA & DVA & 1985 & C & A & - \\
\hline Ellas & Cendata & 1985 & $c$ & $\mathrm{~B}, \mathrm{M}, \mathrm{A}$ & - \\
\hline Qenesys & Brocacef & 1985 & A & A & - \\
\hline HDS & Microcom & 1987 & $\mathrm{C}$ & $\mathrm{B}$ & - \\
\hline H.R.S. & Buro Boelijen & 1986 & c & $\mathrm{B}, \mathrm{M}, \mathrm{A}$ & - \\
\hline Medrian & Janszen Micro & 1982 & C & $\mathrm{B}$ & - \\
\hline Madiprom & Botman & 1982 & C & $\bar{A}$ & - \\
\hline Medsystem & Faber & 1983 & $\mathrm{C}$ & A & - \\
\hline microHIS & w.Wieringen & 1985 & A & $B, M, A$ & + \\
\hline Mini-Declamed & de Cleyenburgh & 1986 & A & $\mathrm{B}$ & - \\
\hline Pat.Reg.Syst. & JCMX-Software & 1984 & $\mathrm{C}$ & $\mathrm{B}, \mathrm{M}$ & - \\
\hline Practisys & Centraal Beheer & 1986 & A & A & - \\
\hline Promedico 2 & $A C S$ & 1982 & A & A & - \\
\hline Rekeningprogr. & Benningshof & 1985 & $\mathrm{C}$ & $B$ & - \\
\hline Sigma PC & Delft/HP & 1985 & C & $\mathbb{B}, \mathbf{M}$ & - \\
\hline
\end{tabular}

- Verkocht per 1 juli 1987: $A=$ meer dan 100 systemen; $C=$ minder dan 50 systemen.

** Modules: $\mathrm{B}$ m basismodule; $\mathrm{M}=$ medische module; $\mathrm{A}$ m apotheekmodule. De basismodule van een aantal van de genoemde software-pakketten was vaak niet veel meer dan een eenvoudig factureerpakket, zoals de naam vaak al suggereert: Dok-programma, Mini-Declamed.

Bron KNMG-katern in Medisch Contact, Dit averzicht is niet volledig. Er waren destijds veel kleine financiële pakketten in omloop die vaak zeer locaal werden gebruikt.

Tabel 2.3 Overzicht van sof tware -pakketten die per 1-7.87 niet meer verkocht werden.

\begin{tabular}{ll|ll}
\hline Software & Bedrif & Software & Bedriff \\
\hline Arts-Fakt & Hornsoft/progr & Commedi & Comma \\
DAP & Atebo & Doksnel & All Well \\
Infocare & Infotheek & Medicad & Cadmoes \\
Med-One & Vertimart & Praxix & Addata \\
Spec.Inf.Sys. & Raet,v/h IGN & WPS & Datapoint \\
\hline
\end{tabular}

nu al gebruik maken van een voorlopige en experimentele versie van de thesaurus en de synoniemenlijst:

- HAG Rijkswiversiteit Limburg. Een aantal medewerkers werkte in 1983 mee aan enkele onderdelen van het RIVOG-HIS project: de systeemanalyse en het uittesten van een HIS-prototype. Bovendien werd een aantal jaren meegewerkt aan het uittesten van de 
Reason for Encounter (RFE)-codes en de ontwikkeling wan de $1 \mathrm{CPC}{ }^{20} \mathrm{De}$ teeds in 1983 gestarte ontwikkeling van een Huisarts Informatie en Onderzoek Systeem (HIOS) werd in 1985 grotendeels overgenomen door de vakgroep Medische Informatica en Statistiek. Het Registratienet Huisartspraktijken (RNH) automatiseerde in 1988 een groot aantal praktijken, die via een academiseringscontract werden betrokken bij dataverzameling in de praktijk (zie hoofdstuk 5). Sindsdien wordt ook actief deelgenomen aan de verdere ontwikkeling van het gebruikte Huisarts Informatie Systeem (microHIS).

- HAG Rijksuniversiteit Utrecht. Vanaf 1987 is hier meegedacht en meegewerkt aan de ontwikkeling van een medische module voor het DECLAMED-HIS, om zo een goed instrument in handen te krijgen voor geautomatiseerde medische registratie en onderzoek in de huisartspraktijk. Deze module is in 1989 voltooid. ${ }^{29}$

- HAG Katholieke Universiteit Nijmegen. Vanuit deze vakgroep werden de eerste naw scholingscursussen over huisartsen-automatisering georganiseerd. Sinds 1985 speelt deze vakgroep ook een belangrijke rol bij de begeleiding en advisering rondom de sutomatisering van een groep huisartsen. Het project Continue Morbiditeits Registratie (CMR), dat al vanaf 1967 loopt, wordt besproken in Hoofdstuk 4.

- MIS Vrije Universiteit Amsterdam. Hier ligt de bakermat van het "Elias"-HIS", dat samen met het softwarehuis Cendata werd ontwikkeld wan 1984 tot 1987 , in samenwerking met een aantal huisartspraktijken.

- MIS Erasmus Universiteit Rotterdam. De komst van Prof. dr. J.H. van Bemmel bij het opstarten van deze vakgroep in 1987 garandeerde een voortzetting van de activiteiten van MI/S van de Vrije Universiteit Amsterdam op deze lokatie. De vakgroep werkt mee aan de ontwikkeling van nieuwe faciliteiten voor het Elias-HIS in overleg met het systeemhuis Cendata. ${ }^{30} 31$

- MIS Rijksuniversiteit Limburg. Vanaf 1985 wordt hier gewerkt aan de ontwikkeling van een Huisarts Informatie en Onderzoeksysteem (HIOS), tot einde 1987 samen met een softwarehuis. Deze HIOS-software verkeert nog in een experimenteel stadium. ${ }^{32}$ Vanaf 1986 is deze afdeling ook de motor van het 3I- Project (Interinstitutionele Informatieuitwisseling in de gezondheidszorg). ${ }^{33}$

\subsection{De stand van zaken in 1990}

De beroepsverenigingen spelen een belangrijke rol bij de automatisering van huisarts praktijken. De tijdige oprichting van de WCIA en het nog steeds daadkrachtig functioneren van deze werkgroep zijn hierbij een belangrijke factor. De duidelijke opstelling en gecoördineerde aanpak van LHV en NHG hebben ervoor gezorgd, dat artsen die willen automatiseren, gebruikers en industrie weten waar ze aan toe zijn.

Rondom elk getoetst HIS heeft zich inmiddels een gebruikersvereniging gevormd, die de leden ondersteunt bij het automatiseren, opkomt voor de belangen van de leden en meedenkt over ontwikkelingen en standaarden. Per 15 juni 1989 waren in totaal 890 praktijken lid van een gebruikersvereniging en/of hadden een erkend HIS-programma gekocht. Hanteert men als rekenfactor 1.8 arts per praktijk, dan komt dit neer op 1600 huisartsen. Het totaal aantal geautomatiseerde huisartsen werd geschat op $25 \%$ tot $35 \%$ van alle praktiserende huisartsen. ${ }^{2-4}$ Hoewel hier geen exacte cijfers over bekend zijn, mag 
worden aangenomen dat de meeste van deze huisartsen slechts hun financiele registratie hebben geautomatiseerd w voor hun medische registratie nog gebruik maken wan de 'groene kaart'.

De industrie heef inmiddels (peildatum 1 januari 1990) 7 door de WCIA getoetste en als "voldoende" beoordeelde Huisarts Informatie Systemen op de markt gebracht. De medische module, met daarin de joumaal-en probleemlijst-registratie, voldoet slechts bij 4 wan deze systemen aan het referentie-model van de WCIA (rabel 2.1).

De vakgroepen Huisartsgeneeskunde gaan ieder door op de ingeslagen individuele weg en hebben daamaast regelmatig contact binnen het reeds eerder vermelde IOH en $10 H O S$.

\subsection{Verwachtingen voor de toekomst}

'Tedereen heeft de neus gesnoten de modder van her brein ligt thuis in het fonteintje"

Lucebert in "roost de hysterische robot", 1989

Vanuit eigen jarenlange automatiseringservaring wil ik als afsluiting van dit hoofdstuk een uitspraak doen over de huidige trends in de automatisering van huisartspraktijken. Enige relativering is hierbij op zijn plaats. De volgende trends zijn te bespeuren: ${ }^{35-37}$

- De automatisering van huisartspraktijken zal zich heel snel gatan voltrekken; vooralsnog zal het vooral automatisering van de financièel-administratieve praktijkvoering betreffen. De "vloedgolf" komt, zij het wat later..." 3234

- Nieuwe '2e generatie' huisartsinformatiesystemen en nog snellere hardware zullen steeds meer huisartsen er toe brengen om ook de medische patiëntgegevens aan de computer toe te vertrouwen.

- Er zal snel een communicatiestandaard worden gedefinieerd of "de facto" ontstaan. Hierna zal binnen enkele jaren de geautomatiseerde communicatie tussen huisartsen onderling en de communicatie binnen de driehoek "huisarts - ziekenhuis - apotheker" tol gemeengoed worden.

- Er wordt een medische standaard voor de "chipkaart" (de medicard) ontwikkeld. Hierna zullen deze 'medicards', die voorzien zijn van minimaal $64 \mathrm{~K}$ geheugen, geleidelijk een eigen platats veroveren in de communicatie tussen patiënt en medische hulpverlener en bij het vastleggen van medische gegevens. 3839

- CD-ROM technologie en "retrieval-software" zullen over enkele jaren uitgerijpt en betalbaar zijn. Het dan inmiddels grote antal geautomatiseerde (huis)artsen maakt het interessant voor data-leveranciers om artsen individuelle abonnementen op grote medische databestanden an te bieden. Te denken valt hierbij aan literatuur-overzichten, bijgewerkte medicijnbestanden met up to date interactie- en contraindicatie- bewaking, volledig actuele adresbestanden en medische naslagwerken.

- Bij nascholing van artsen zal steeds meer gebruik gemaakt worden van interactieve computer-programma" s met grafische mogelijkheden.

- De autornatisering van huisartspraktijken zal niet de weg openen naar een algemeen 
aanvaarde alles dekkende data-dictionary, een soort medisch Esperano. Huisartsen zullen individualisten bljven en grenzen stellen aan beperkingen van hun expressievrijheid.

- Geautomatiseerde beslissings-ondersteunende systemen zullen op de duur zo ver ontwikkeld worden, dat ze de huisarts op een huisartsvriendelijke manier kunnen ondersteunen bij zijn medisch diagnostisch handelen. ${ }^{40-43}$

\section{Literatuur}

1 Springer MP, Slager JN, Perk MA van der. Waarom automatiseren in de huisartspraktijik? Med Contact $1984 ; 39 ; 1445-6$.

2 LHV-Symposium. De geautomatiseerde huisarts in het Dekker tijdperk. Ede 1989.

3 Daniels $\mathbb{E}$, Coulter $\mathrm{A}$. How to choose a general practise computing system: comparision of commercial packages. Br Med J 1988;297:838-40.

4 Mills KA, Steele K, Irwin WG. A computerized audit of non-steroidal anti-inflammatory drug prescribing in general practice. Fam Pract 1988;5;40-5.

7 Stavem K, Ostbye T. EDB for primaerleger. Status og utvikling. (Computer systens for general practitioners. Status and development) Tidsskr Nor Laegeforen 1989;109:700-3.

8 Schmittling GT. Computer use by family physicians in the United States. J Fam Pract $1989 ; 29 ; 198-200$.

9 Hoekstra M, Bosch WJHM van den, Hoogen HJM van den. Naar een informatienetwerk in de Eerste Lijn. Rapportage. Utrecht: Nederlands Huisartsen Instituut, 1981.

10 Krutzen FM. Huisarts Informatie Systeem (HIS); onderzoek naar. automatiseringsmogelijkheden in de huisartspraktijk. Rapport RIVOG, deel 1, ni 85.0217, Rijswijk: Ministerie van WVC, 1985.

11 Geus CA de, Höfen R.von, Metsemakers JFM. Huisarts en computer. Op weg naar een geautomatiseerd registratiesysteem yoor wetenschappelijk onderzoek. in de huisartspraktijk. Med Contact 1984;19:1289-90.

12 Anoniem. Huisartsensystem komt van de grond. Automatiseringsgids; AG-rapport nov/dec 1984.

13 Cromme PVM. Huisarts en informatisering. Ned Tijdschr Geneeskd 1985;129:1576-8.

14 Westerhof HP. Het Nederlandse Referentiemodel voor Huisarts Informatie Systemen. Antwerpen 1989; MIC' 89 proceedings 139-45.

15 Voort $\mathrm{H}$ van der. De invoering van de automatisering nader onderzocht. Huisarts Wet $1988 ; 31: 114-5$.

$16 \mathrm{KNMG}$ (katern MC). Artsen en Automatisering: een SDM-aanbod. Med Contact $1986: 41: 41-2$.

17 Overdijk T. De computer als hulpmiddel bij de praktijkvoering. Huisarts Wet $1975_{n} 18: 182-3$.

18 Hoogen J van de, Brasse M. Huisarts en computer. Med Contact 1984;39:593-5.

19 Manders JW. Automatisering van de patiëntenregistratie. Huisarts Wet 1986;29:387-9.

20 Botman J. Automatiseren in de huisartspraktijk. Med Contact 1984;39:1291-5.

21 Zwaan FW. Computerisation, a positive contribution for the quality of the work of the General Practitioner. Proceedings of the Medinfo 83 seminars. Amsterdan, 1983.

22 Guldemond F, Höppener P, Schendel G van. Huisarts en computer. Med Contact $1986 ; 41: 77-8$.

23 Klaver L. Huisarts en Computer. Ronde-tafel gesprek gebruikersverenigingen. Praktijkmanagement $1988 ; 12-4: 17-24$.

24 Werkgroep Coördinatie Informatie Automatisering. Verslag van de hearing op 11 october 1984. Utrecht 1984.

25 Mulder Dzn ID. De werkgroep Classificatie en Codering wan het IOH. Huisarts Wet $1987 ; 30: 55$

26 Lamberts H. Conversie tabellen ICPC. Amsterdam: Instituut voor Huisartsgeneeskunde 


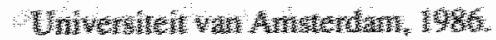

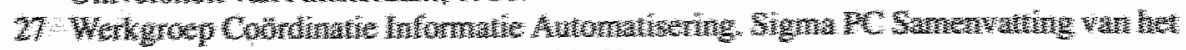

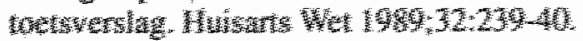

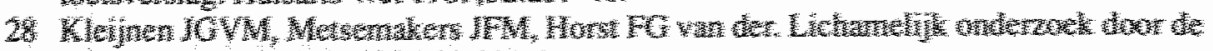
W

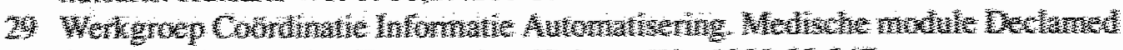

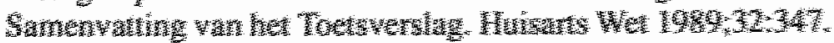

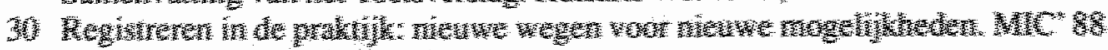

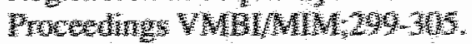

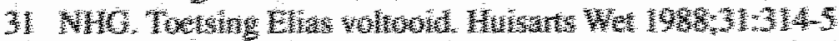

32 Dithon

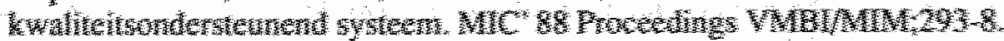

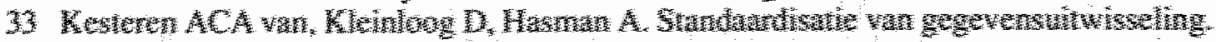

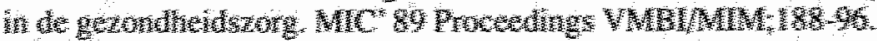

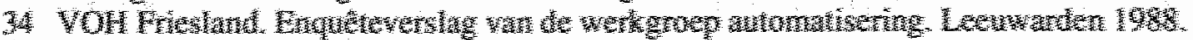

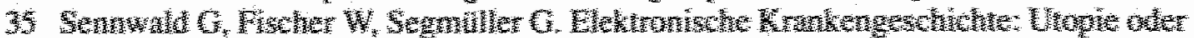

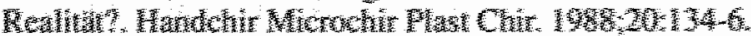

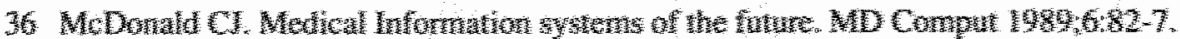

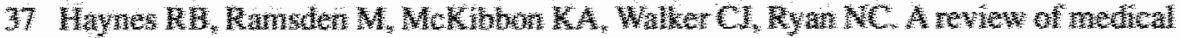

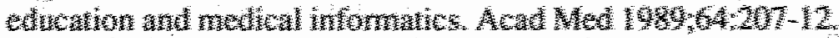

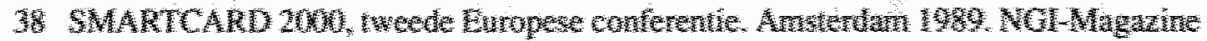

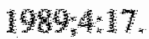

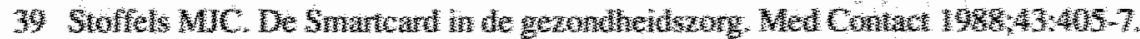

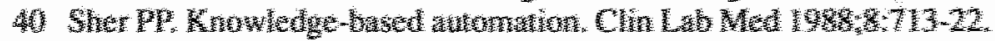

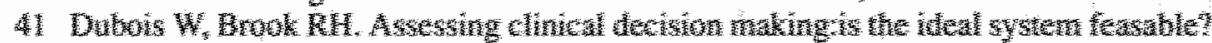

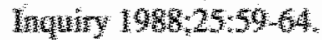

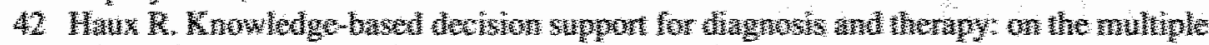

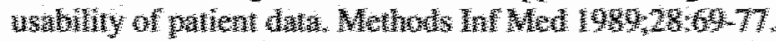

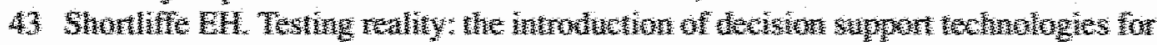

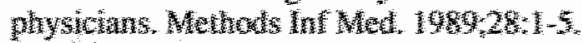

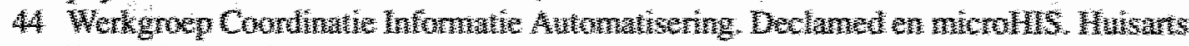
We $1987,30,84.5$.

4 Werkgots Coom

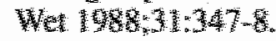

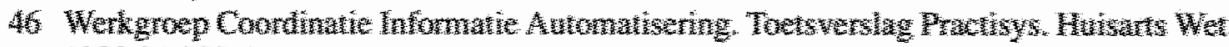
$1968,31,383-4$.

47 WCIA. Amice , versie F. Samenvatting van toetsverslag. Huisarts Wet 1989;32:147-8. 


\section{Automatisering in Huisarts en Wetenschap: een analyse van gepubliceerde onderzoekverslagen}

Samenvatting Aan de hand van een literatuuronderzoek wordr in dit hoofdstuk nagegaan, in hoeverre automatisering al een rol wan betekenis heeft gespeeld bij patièntgebonden huisartsgeneeskundig onderzoek. Het blijkt dat de computer reeds vaak wordt gebruikt voor centrale gegevensopslag en soms ook ondersteuning biedt bij literatuuronderzoek en bij de statistische bewerking van onderzoeksgegevens. Geautomatiseerde dataverzameling aan de basis - in de huisartspraktijk - blijkt nog geen rol te spelen. De uitkonsten van deze studie leiden tot een positieve uitspraak over de meerwaarde van praktijkautomatisering bij een aantal typisch huisartsgeneeskundige onderzoekmethoden.

\subsection{Inleiding}

De microcomputer heeft in 1979 zijn intrede gedaan in de Nederlandse huisartsenwereld en speelt een steeds belangrijker rol bij de ondersteuning van de praktijkvoering. Tien jaar eerder al hadden mainframes en minicomputers hun plaats weroverd in de Nederlandse ziekenhuizen en medische faculteiten.

In het kader van de probleemstelling van deze dissertatie is het van belang om na te

Tabel 3.1 Overzich van 25 periodieken die regelmanig doar de postbode bij de Nederlandse huisarts warden bezorgd.

De Medische Spiegel

De Medicus

De Papieren Visite

De Vrouwelijke patiënt

Folia Rheumatologica

- Geneesmiddelen Bulletin

Hart Bulletin

Hart \& Vaten

Huisarts en Cara

- Huisarts en Wetenschap

Huisartsgeneeskunde voor

55-plussers

Janssen Medisch.

Wetenschappelijk Nieuws

- Medisch Contact

Modern Medicine (Nederlandse uitgave)
- Nederlands Tijdschrift voor Geneeskunde

Nieuwsblad Gezondheidszorg

Organorama

Patient Care (Nederlandse uitgave)

Praktijk Management

Rheuma \& Trauma

Sandorama

The Practitioner (Nederlandse uitgavel

Tijdschrift SDO

Tijdschrift Geneesmiddelen Onderzoek (TGO)

Vademecum permanente nascholing huisartsen

Toelichting De met - gemerkte tijdschriften worden alleen toegezonden aan leden van werani* gingen of aan abonnees. 
gaan in hoewerre atutomatisering een rol heeft gespeeld bij de uitwoering en ondersteuning van wetenschappelijk onderzoek in de huisartspraktijk. Met name is daarbij interessant om na te gatan welke rol de automatisering van de huisartspraktijk zelf heeft gespeeld. Heeft het gebruik van een Huisarts Informatie Systeem (HIS) met contactregistratie, vastleggen van journaal en probleemlijst al tot wetenschappelijk onderzoek geleid?

Vanaf 1980 werd door mij een databestand opgebouwd van trefwoorden die verwijzen naar artikelen die zijn gepubliceerd in een aantal tijdschriften, die door de meeste Nederlandse huisartsen gelezen (kunnen) worden. Tabel 3.1 geeft een overzicht van deze periodieken. Het betreft hier voornamelijk publicaties over huisartsgeneeskunde en over praktijkorganisatie. Dit databestand werd doorzocht on na te gaan of reeds eerder werd gepubliceerd over de rol yan de praktijkautomatisering bij wetenschappelijk onderzoek in de huisartspraktijk. Tevens werd een literatuuronderzoek uitgevoerd via de bibliotheek-computer van de Rijksuniversiteit Limburg. De Index Medicus van de MEDLINE databank op CD-ROM (Silver Platter) werd begin februari 1990 geraadpleegd.

Publicaties speciaal over de rol die automatisering van de huisartspraktijk ('perifere automatisering') heeft gespeeld bij reeds uitgevoerd wetenschappelijk onderzoek werden niet gevonden. Wel werd al gepubliceerd over het gebruik van sex-age registers in de praktijkcomputer voor het in kaart brengen van de morbiditeit in het praktijkgebied en voor postmarketing surveillance. ${ }^{12}$

De Nederlandse huisartsgeneeskundige literatuur werd bestudeerd om een antwoord te vinden op de volgende vragen:

1 Welke rol heeft de automatisering tot nu toe gespeeld bij huisartsgeneeskundig onderzoek:

- literatuursearch;

- verzameling van data aan de bron via een Huisarts Informatie Systeem (HIS);

- de opslag en bewerking van data in centrale bestanden;

- statistische bewerking van de data?

2 Wat is de geschatte meerwaarde van de geautomatiseerde dataverzameling aan de basis via de praktijkcomputer van de huisarts? Wat is de meerwaarde van data-opslag en bewerking in een centraal opgestelde computer?

3 Welke onderzoekmethoden hebben baat bij automatisering van de huisartspraktijk via een HIS?

\subsection{Methode}

Het lag voor de hand om een explorerend literatuuronderzoek, dat een antwoord zou kunnen geven op deze vragen, eén decennium te laten bestrijken: de periode van oktober 1979, het oprichtingsjaar van de werkgroep 'huisarts en computer', $t /$ m oktober 1989 , het tijdstip waarop dit onderzoek werd uitgevoerd. Het onderzoek werd beperkt tot publicaties in het tijdschrift 'Huisarts en Wetenschap' omdat dit tijdschrift bij uitstek het forum is voor huisartsgeneeskundige publicaties in Nederland. Een groot aantal verslagen van origineel patiëntgebonden huisartsgeneeskundig onderzoek in de geselecteerde 10 jaargangen van 'Huisarts en Wetenschap' werd geanalyseerd. Met name werd veel aandacht besteed aan de hoofdstukken "methode' en 'resultaten" én aan de literatuurreferenties. 


\subsubsection{Selectie en beoordeling}

De nader te onderzoeken publicaties werden geselecteerd op onderstaande inclusiecriteria:

- gepubliceerd in "Huisarts en Wetenschap";

- periode van oktober $1979 \mathrm{t} / \mathrm{m}$ oktober 1989;

- onderzoek betreffende huisarts-patiënt contacten:

- onderzoek van door de huisarts geregistreerde patiëntgebonden gegevens.

Onderzoekverslagen die niet aan deze criteria voldeden werden niet geselecteerd. Met name ging het hier om publicaties met als onderwerp: attitudes van huisartsen, ${ }^{3}$ bevolkingsonderzoek, dat geen gebruik maakt van de individuele patièntendossiers bij de huisarts, ${ }^{4}$ secundaire analyses van al eerder verzameld materiaal, waarbij niet opnieuw wordt teruggegaan naar de gegevens van de individuele patiënt bij de huisarts, ${ }^{5}$ en de algemene werkwijze van huisartsen.

Elke geselecteerde publicatie werd door de onderzoeker beoordeeld op onderstaande items:

- verwachte meerwaarde van automatisering voor het beschreven onderzoek;

- indicaties voor literatuuronderzoek via de computer;

- dataverzameling bij de huisarts;

- centrale dataverzameling en bewerking;

- statistische bewerking van de data;

- verbinding van het onderzoek met een groter onderzoekproject of instituut (omdat in dat geval voorondersteld mag worden dat computerfaciliteiten aanwezig zijn).

\section{Meerwaarde automatisering}

Bij elk van de bestudeerde onderzoekverslagen werd een beoordeling gegeven van de verwachte meerwaarde van de automatisering bij betreffend onderzoek. Dit gebeurde ook, wanneer de computer in werkelijkheid geen enkele rol had gespeeld. Het meest in aanmerking kwam de indeling volgens een ordinale schaal: categorieën met oplopende hiërarchie wat betreft de 'meerwaarde van automatisering'.

1 Geen voordeel, eerder nadeel (bijwoorbeeld: privacy-aspecten komen in het gedrang).

2 Neutraal: geen voordeel, geen nadeel. ${ }^{27}$

3 Vergemakkelijkt het onderzoek en/of maakt het onderzoek efficiënter, bijwoorbeeld:

- retrospectief terugzoeken van dossiergegevens na een periode van case-finding; ${ }^{51}$

- via tevoren aangebrachte ruitermarkering selectie van patiënten terugzoeken; ${ }^{98}$

- enquête/mailing na een periode van case-finding; ${ }^{54}$

- mailing aan alle patiènten (gebruik van een adresbestand). ${ }^{56}$

4 Grote meerwaarde: verhoogt aanzienlijk de opbrengst en de efficiëntie van het onderzoek:

- opzoeken van een patiënten-subpopulatie met behulp van een eerder aangelégde diagnose-index ${ }^{80}$

- gebruik van grote controle-groepen; ${ }^{52}$

- opzoeken van een patiënten-subpopulatie via een centrale morbiditeitsindex; ${ }^{86}$

- registratie van contactfrequenties over een periode langer dan 3 maanden, ${ }^{35}$

- aselecte steekproef uit de kaartenbak. ${ }^{89}$ 
5 Bija onmisbaar. Onderzoek zonder geautomatiseerde medische of famacologische verslaglegging bij de his ists is "monnikenwerk" of "een heidens karwei" :

- het doorpluizen wan kaurtenbakken woor retrospectief onderzoek:

- retrospectieve controle op medicatie wia de kartenbak of via

- de apotheekadministratie van de apotheekhoudende huisarts; ${ }^{85}$

- zeer uitgebreide inhoudelijke regustratie van alle contacten over periode langer dan 1 matand; 78

6 Onmisbaar. De computer maakt onderzoek mogelijk, dat woorheen vijwel niet gerealisederd Kon worden. ${ }^{34}$

\section{Indicaties literatiuronderzoek via de computer}

De meeste auteurs verzamelen nog steeds hun literatuur op de traditionele wijze: via gericht lezen, bewaren van vakliteratuur en bijhouden van een kaartsysteem. Vaak wordt belangrijke informatie aangetroffen in de 'afgeleide referenties' bij overzichtsartikelen. Daarnaast wordt steeds meer gebruik gemaakt van literatuursearch via een bibliotheekcomputer of worden grote literatuurbestanden geraadpleegd, die beschikbaar zijn op CDROM of die on-line benaderd kunnen worden.

Bij dit onderzoek werden de lijsten met literatuur-referenties bij de geselecteerde verslagen beoordeeld volgens een experimentele punten-schaal, die was ontworpen om de waarschijnlijkheid van computergebruik bij literatuuronderzoek te scoren.

- Aantal referenties: per referentie 0.1 punt

- Aantal 'buitenlandse' referenties:

$-30 \% 1$ punt;

- 60\% 2 punten

- Diversiteil van de bron(nen), indien meer dan 6 referenties én

$-50 \%$ uit verschillende tijdschriften 1 punt

$-75 \%$ uit verschillende tijdschriften 2 punten

- $90 \%$ uit verschillende tijdschriften 3 punten

- De auteur(s) zijn verbonden aan een groot instituut of groot project 1 punt

Vijftien publicaties van atteurs, waarvan de werkwijze aan de onderzoeker bekend was, werden beoordeeld volgens deze puntenschaal. Indien gebruik was gemaakt van literatutrsearch via de computer werd een score van 5.5 of hoger behald (sensitiviteit $100 \%$ ).

L. Het is waarschijnlijk dat gebruik gemaakt is van Literatuur-search via de computer wanneer de lijst met literatuur-referenties een score haalt van 5.5 of meer punten.

$Z$ In het artikel wordt vermeld, dat er een geautomatiseerde literatuursearch is verricht.

\section{Dataverzameling aan de basis bij de hwisarts}

Ook de dataverzameling aan de basis bij de huisarts is beoordeeld volgens een hiërarchische schanl $(\mathrm{A}-\mathrm{H})$ :

A Geautomatiseerd en up to date gehouden Adressen-bestand.

D Geautomatiseerde Diagnose-index, die wordt bijgehouden in de praktijkcomputer.

P Geautomatiseerde Probleemlijstregistratie.

H Volledig HIS met geautomatiseerde registratie van naam en adres gegevens, achtergrondgegevens, contactrequentie, journaal, probleemlijst en medicatie. 


\section{Centrale dataverzameling en bewerking}

C Het is duidelijk dat een Centraal opgestelde computer (mini-of mainfrane) werd gebrukt voor opslag van alle geregistreerde data en/of de onderzoekresultaten zijn af komstig uit meerdere praktijken of van een bevolkingsonderzoek.

K Centrale inhoudelijke Kontrole op alle verzamelde data: in het artikel wordt vermeld dat van een centraal computersysteem gebruik gemaakt werd voor:

- centrale opsiag van de onderzoekgegevens en

- centrale computerbewerking van de gegevens en/ol:

- inhoudelijke controle van de onderzoekdata.

\section{Statistische bewerking van de data}

S In het onderzoekverslag wordt duidelyjk vermeld welke Statistische methode van databewerking is toegepast, bijvoorbeeld: chi-kwadraat, student- $\mathrm{T}$ test. Er wordt geen $\mathrm{S}$ toegekend indien enkel in het dankwoord of in de lijst van auteurs wordt vermeld dat een statisticus heeft meegewerkt aan het onderzoek.

$\mathbf{X}$ In het onderzoekverslag wordt duidelijk vermeld dat gebruik werd gemaakt van een computer en/of software bij de statistische bewerking van de onderzoekgegevens.

\section{Onderzoekproject en/of instituut}

Veel onderzoekers zijn verbonden aan een huisartseninstituut, een aantal praktijken neemt deel aan grote registratieprojekten. Wanneer dit duidelijk was zijn de universitaire huisartsinstituten en de regïstratieprojecten benoemd.

\subsubsection{Random-toetsing van de bevindingen}

Om de resultaten van het onderzoek verder te objectiveren en te toetsen werd in tweede instantie de hoofdauteur van elke achtste publicatie uit het literatuuroverzicht in tabel 3.2 telefonisch geënquêteerd. Indien deze auteur niet bereikbaar was, werd Een van de medeauteurs benaderd of de hoofdauteur van de voorafgaande of hierop volgende publicatie in het literatuuroverzicht.

In tabel 3.2 werd met cursief aangegeven welke auteurs telefonisch zijn benaderd met onderstaande vragen:

1 Hebt u bij het opzoeken en selecteren van literatuur referenties gebruik gemaakt van een computersearch?

2 Is bij het onderzoek gebruik gemaakt van gegevens die waren opgeslagen in een praktijkcomputer?

3 Werden de onderzoekdata systematisch opgeslagen en bewerkt in een centraal gelocaliseerde computer?

4 Hoe werden de data statistisch bewerkt?

Indien hierbij een computer werd gebruikt: welk statistisch softwareprogramma (naarn, versie)?

De kappa van Cohen werd gebruikt om de overeenstemming tussen beoordeling door de onderzoeker en beantwoording door de oorspronkelijke auteur uit te drukken. 


\section{3. Resultaten}

Bij bestudering van "methode" en "resultaten" komt slechits bij 39 (37\%) van deze verslagen de conclusie naar voren, dat bij het verwerken van de onderzoekgegevens gebruik werd gemaakt van een centrale, niet in de praktijk van de huisarts opgestelde, computer. Meestal betreft het dan in deze centrall opgestelde computer vastgelegde morbiditeitsgegevens, die afkomstig zijn van grote registratieprojecten waar meerdere praktijken bij

Tabel 3.2 Literatuaroverzicht.

Nr, auteur(s), (verkorte) titel

Mwlt Ha Mt St Project

6 Adam \& Ten Cate, De visite in de huisartspraktijk

7 De Geus et al., Samenwerking tussen huisarts en psycholoog

8 Bremer, Gebruik huisartsen-anamneselijst bij vage, onduidelijke klachten

9 Lamberts, Primary health care monitoring project

10 Seelen et al, Identification of cardiovascular risk factors

11 Van der Ploeg, Persoonlijkheidskenmerken en huisartscontact-frequentie

12 Van Koningsveld \& Weyenburg, Nabestaan, een naar bestaan

13 Crebolder, Over sterven en stervensbegeleiding

14 Van Weal \& Tielemans, Diabetes mellïtus in een huisartspraktijk

15 Bekker \& Prins, Bloeddrukdaling na interventie door de huisarts

16 Crul, De invloed van de huissarts op het kortdurend ziekteverzuim

17 Knottnerus \& Sommers. Werken en niet kumnen werken

18 Meijer, De diagnose irritable bowel syndroom

19 Van der Feen, Zes jaar later

20 Van Weal, De voor hypertensie behandelde populatie

21 Crebolder, Gebruik en gebruikers van fysiotherapeutische behandelingen

22 Roolvink, Registratie van kanker in een huisartspraktijk

23 Prins, Enkele aspecten van hypertensiebestrijding

24. Meyboom, De beperkingen van cardiofonie 25 Meijman et al, Anticonceptie en kinderwens

$$
\begin{aligned}
& 3----\mathrm{Hag} \\
& 2--\cdots \\
& 2 \mathrm{~L}-\mathrm{-} \\
& 5 \mathrm{~L}-\mathrm{K}-\text { Mon } \\
& 4 \text { - }-\quad \text { Hag } \\
& 4--C S
\end{aligned}
$$

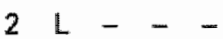

$$
\begin{aligned}
& 3--\cdots \\
& 5--- \\
& 3--\ldots \\
& 3--- \\
& 3--- \\
& 4-\text { - C S } \\
& 3--- \\
& 4 \text { - }-C \text { - Mon } \\
& 3- \pm- \\
& 5-\ldots- \\
& 3-\ldots+\text { Hag } \\
& 3--- \\
& 3--\mathrm{CS}
\end{aligned}
$$


zijn betrokken (tabellen 3.2, 3.4 en 3.5). In vijf van deze 39 verslagen wordt expliciet vemeld dat een centraal computersysteem wordt gebruikt voor verdere bewerking en inhoudelijke controle van de geaggregeerde gegevens. Slechts éen van de 105 onderzoekers laat weten dat bij een onderzoek binnen de eigen groepspraktijk de onderzoekresultaten werden verkregen uit het "Naam-Adres-Woonplaats" (NAW) bestand in de praktijkcomputer. ${ }^{40}$ Uit geen enkel ander onderzoekverslag blijkt, dat gebruik werd gemaakt van gegevens die waren opgeslagen in een praktijkcomputer.

Tabel 3.2 Literaiuuroverzicht (vervolg).

Nr, auteur(s), (verkorte) titel

Mwlt Ha Mf st Project

26 Van Weel \& Van Zelst, Diabetes mellitus in een huisartspraktijk II

27 Cottaar et $\mathrm{al}_{*}$, Röntgenonderzoek in de huisartspraktijk

28 Thomassen \& De Nood, Communicatie en compliantie

29 Damstra-Wijmenga, Veillig bevallen: thuis of (poli)klinisch?

30 Hirschfeld, Het pessarium occlusivum

31 Van den Bosch, Het pessarium als behandeling voor prolaps van de vagina

32 Terluin, Het hyperventilatiesyndroom. 1. Een beschrijving van 78 patiënten

33 Terluin, Het hyperventillatiesyndroom

2. Een evaluatie van de behandeling van 74 patiënten

34 Lamberts et al. Waarom gaat iemand naar de huisarts?

35 Meyboom et al. Het voorschrijven van geneesmiddelen aan kleine kinderen

36 Van der Wal \& Smeenk, Bewerkelijkheid nadier bekeken

37 Van Akkeren \& Veeninga, De behandeling van patiënten met chronisch klaaggedrag

38 De Haan, Turkse, Marokkaanse en Nederlandse jongeren

39 Ter Braak \& Van der Werf, Verwijzen of niet?

40 Breijer \& Lamberts, Hoe kiest de patiënt zijn huisarts?

41 Meijman, Twaalf jaar cervixcytologie

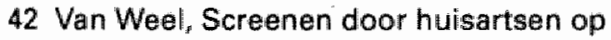
cervixcarcinoom

43 Schellekens et al., Leeftijd en morbiditeit

44 Van der Wal et al., Vijf jaar spiraaltjes in een huisartspraktijk

45 Van Ree et al. Interventie bij een verhoogd risico op hart-en vaatziekten 
Tabel 3.2 Literaituuroverzich (wervolg).

46 Knook, Radiogram wan een wrije vestiging

47 Van Ree et al., Interventie bil een verhoogd risico op hart-en vaatziekten

48 Roelfsema, Begeleiding van kankerpatiënten

49 Van den Bosch, Het Lentse dodenboekje

50 Van der Zee, Oudere patiênt en psychosociale problematiek

51 Knottnerus et al. Klachten op de borst

52 Baselier, Recidiverende acute bacteriële urineweginfecties

53 Van Weel C, Screenen door huisartsen op cervixcarcinoom

54 Mesker-Niesten, et al. Ervaringen van IUD. gebruiksters

55 Van Duijn et al., Een onderzoek naar het bestaan van een spaanplaatsyndroom

56 Post \& Gubbels, Hoofdpijn in een huisartspraktijk

57 Slegt \& Kessel-Al, Zlektegedrag van allochtone patiënten

58 Esser \& Van Weel $C_{n}$ Het beloop van uitstralende rugpijn

59 Verkes \& Van Megchelen, Nek-en rugpijn bij gevoelens van agressie en onmacht

60 Van den Bosch, Kanker in vier huisartspraktijken

61 Van der Meijden et al., Vaginale afscheiding: wat zeggen vrouwen er zelf over?

62 Bergenhenegouwen, Melkzuurspoelingen bi] vaginitis

63 Meyboom-de Jong et al ${ }_{\text {, }}$ De functionele toestand van patiënten

64 Tempelaar, Sterfte en iatrogene schade

65 Lagro-Janssen, Nooit op tijd

66 Lagro-Janssen \& Van Manen, Alles weggehaald... 1. De relatie tussen uterusextirpatie en medische consumptie

67 Lagro-Janssen et al., Alles weggehaald...

2. Kenmerken van vrouwen die een uterusextirpatie hebben ondergaan

68 Mens, Moeders voor snoepers?

69 Avezaat \& Lutjenhuis, Ulcus pepticum bij allochtone Nederlanders

70 Tillema, Hoe vergaat het de patiënt na cardiofonie?

$$
\begin{aligned}
& 5--- \\
& 3--C S \text { NIP } \\
& 2--- \\
& 2---- \\
& 2--- \\
& 3---- \text { Hag } \\
& 4-- \text { C S CMR } \\
& 3---- \text { Omm } \\
& 3--- \\
& 3 \text { L }-- \\
& 3---\infty \mathrm{Hag} \\
& 4---\div \\
& 4 \text { - C S Mon } \\
& 3--- \\
& 4--C-\text { CRM } \\
& 2=-- \\
& 3--- \\
& 31-- \\
& 5-2 \leq \\
& 4--C-\text { CMP } \\
& 4-- \text { C S }
\end{aligned}
$$$$
3-\because C-C M R
$$$$
2---
$$$$
5---
$$$$
2--\div-
$$ 
Talbel 3.2 Literatumoverzicht (wervolg).

Nir, auteur(s), (verikorte) titel

Nwwt Ha Nit St Project

71 Terluin, Surmenage in een huisartspraktijk

72 Meijman, Cervixcytologie via een actieve benadering

73 Kuyvenhoven \& De Melker, Verwijzingen naar interne en chirurgische specialismen

74 Wevers \& Van der Leden, De hulp van de huisarts aan ouderen

75 Knottnerus et al., Diagnostische conclusies van de huisarts naar aanleiding van onverklaarde moeheid

76 Aulbers B.JM. Voetklachten in een huisartspraktijk

77 Lagro-Janssen, Een plaats om te sterven... voor man en vrouw gelijk?

78. Lamberts et al. Het transitiemodel in de huisartspraktijk

79 Meijman, Gynaecomastie bij jong volwassenen

80 Meijman, Geregistreerde problemen tijdens 3608 pillcontroles

81 Prins \& Roelofs, Zeven jaar later

82 Van den Hoogen et al. Een semi-geautomatiseerd hypertensiebewakingssysterem

83 Verbeek, Polymyalgia rheumatica acuta en arteriitis

84 Muris et al. De waarde van auscultatie bij de diagnostiek van bronchusobstructie

85 Meyboom, Digoxine in een huisartspraktijk

86. Van Eijk et al. Veranderingen in het morbiditeitspatroon van nabestaanden

87 Meijman, AIDS-problematiek in twee Amsterdarnse huisartspraktijken

88 Smits et al., 'Ze stuurden me naar de dokter'

89 Van Vliet et al., De pilcontrole afgeschaft, opluchting of gemis?

90 Aussems et al., Huisarts en incest

91 Meurs \& Verbeek-Heida, Compliantie bij antibiotica

92 Rutten et al., De type-1I diabeet: hoe staat het ermee?

93 Plaggie et al. Het voorschrijven van geneesmididelen zonder arts-patiënt contact

94 Rempt et al., Ouders van kinderen met CARA ondervraagd

95 Tempelaar et al., Langdurig gebruik van bêta-blokkers en de kwalliteit van het leven 
Tabel 3.2 Literatuuroverzich (vervolg).

96 Van de Lisdonk, Klachten zonder Klagen bij de dokter

97 Wielink, Opname wegens een hypoglykemisch coma

98 Reenders et al., Diabetes mellitus in een groepspraktijk

99 Reenders et al. Diabetes mellitus in een groepspraktijk

100 Lagro-Janssen, Eenmaal een niersteen, altijd een niersteen?

101 Dieleman at al., Compliantie bil astmamedicatie

102 Van Rens et al., Herkenning van problematisch alcoholgebruik in de huisartspraktijk

103 Jol \& Verhaak, Psychische en sociale klachten

104 Bremer, Een onderzoek naar verwijsbrieven

105 Francheboud et al. Thuisbehandeling na een acuut hartinfarct

106 Van den Bosch \& Van Weel, Leeftijd-en geslachtsverschillen bij fracturen en andere traumata

107 Walma et al, Diureticagebruik door 65-plussers

108 Krebber et al. Acute buikpijn op een EHBO

109 De Haan, Indicatoren voor CARA bij kinderen

110 Meyboom-de Jong \& Smith, Cerebrovasculaire stoornissen bij ouderen

$$
\begin{aligned}
& 3-\ldots- \\
& 3-\ldots \\
& 3--c-0 m m \\
& 3-\ldots-\text { Omm } \\
& 4--C-\mathrm{CMR} \\
& 3 L-C S \mathrm{Hag} \\
& 3 \text { - - - Hag } \\
& 2 \text { - - C S Niv } \\
& 2--- \text { Hag } \\
& 4--\mathrm{C}-\mathrm{Niv} \\
& 4--C-C M R \\
& 5 \mathrm{~L}-\mathrm{C}-\mathrm{Hag} \\
& 3 L-C-A Z \\
& 5 L-C S \text { Hag } \\
& 4 \mathrm{~L}-\mathrm{C} S \mathrm{Hag}
\end{aligned}
$$

\section{Toelichting bil de afkortingen}

Mw conclusie to.v. vewachte meerwaarde automatisering

Lt literatuur" indicatie woor toepassing van litereturursearch

$\mathrm{Ha}$ gobruk yan praktijkcomputeir door huisarts (peildatum 1 november 1989)

Mi gebruik van centrale computer (mainfiramo)

St vermelding statistische methode

Az Academisch Ziekenhuis

CMA Continue Morbiditeits Registratie (Hag Nijmegen)

Hag vakgroep Huisartsgeneeskunde:

Mon Monitoringproject

NiP Nipimaegs intervent Project

Niv Stichting Nederllands Institutt voor onderzoek van de eerstelijns gozondiheidszorg

Omm Groepspraktijk Ommoond

Tra Transitieproject (Universiteit valn Amsterdam! 
Tabel 3.3 laat een samenvathing zien wan de beoordeling van de geselecteerde onderzoek verslagen op het aspect "werwachte meerwaarde automatisering. Tevens wordt per "cluster" aangegeven welke onderzoekmethode daadwerkelijk het meest frequent wordt toegepast. Dezelfde beoordelingscriteria worden weergegeven in tabel 3.4 , maar dan gecorreleerd an het jaar van publicatie.

Categorie 3 scoort continu het hoogste. Het valt op dat categorie 4 steeds populairder wordt en dat het gebruik van een centraal computerbestand bij onderzoek in deze categorie een normale zaak is.

Bij 20 van de onderzochte lijsten met literaturreferenties wordt volgens de toegepaste puntenschaal een score gevonden van 5.5 of hoger. De mediaan is 3.5 , de $50 \%$ spreiding is 3 punten. Literatuuronderzoek via een geautomatiseerd indexbestand werd volgens de toegepaste puntenschaal zinvol en waarschijnlijk geacht bij $20(19 \%)$ van de 105 geanalyseerde literatuurlijsten (tabellen 3.2 en 3.6 ).

In geen enkel artikel wordt vermeld hoe de literatuurlijst precies tot stand is gekomen.

Tabel 3.3 Beoordeling van de te verwachten meerwaarde van automatisening versus beoordeling werkelijke toepassing.

\begin{tabular}{|c|c|c|c|c|}
\hline \multirow{2}{*}{$\begin{array}{l}\text { Categorie } \\
1\end{array}$} & \multirow{2}{*}{$\frac{\begin{array}{c}\text { Aantal } \\
n=105\end{array}}{0}$} & \multirow[t]{2}{*}{$\begin{array}{l}\text { Meest frequent gebruikte } \\
\text { onderzoekmethode bij } \\
\text { dataverwerking }\end{array}$} & \multicolumn{2}{|c|}{$\begin{array}{l}\text { Gebruik van een } \\
\text { centrale computer } \\
n=39 \quad \%\end{array}$} \\
\hline & & & & \\
\hline 2 & 19 & $\begin{array}{l}\text { Korte periode van case-finding } \\
\text { Evaluatie van gesprekken, } \\
\text { audio- en video-tapes }\end{array}$ & 1 & 5 \\
\hline 3 & 46 & $\begin{array}{l}\text { Retrospectief kaartenbakonder- } \\
\text { zoek na een periode van case- } \\
\text { finding en identificatie van } \\
\text { de te selecteren subpopulatie. } \\
\text { Opzoeken van patiëntdossiers } \\
\text { naar aanleiding van bevolkings- } \\
\text { onderzoek of screening } \\
\text { Enquête bij een subpopultatie } \\
\text { die gedurende een periode van } \\
\text { case-finding is geidentificeerd }\end{array}$ & 13 & 28 \\
\hline 4 & 25 & $\begin{array}{l}\text { Gebruik van een centraal bestand } \\
\text { als index naar een subpopulatie } \\
\text { van eigen patiënten } \\
\text { Het samenstellen van controle- } \\
\text { groepen } \\
\text { Random steekproef uit eigen } \\
\text { patiëntenbestand (kaartenbak) }\end{array}$ & 19 & 76 \\
\hline 5 & 13 & $\begin{array}{l}\text { Het volledig uitpluizen van de } \\
\text { gehele kaartenbak/archief }\end{array}$ & 4 & 31 \\
\hline 6 & 2 & $\begin{array}{l}\text { Uitgebreide contactregistratie } \\
\qquad>1 \text { maand }\end{array}$ & 2 & 100 \\
\hline
\end{tabular}

Categorieên 1 meen woorcleel, eerder nadeet: 2 = geen woordeel, geen nadeal; 3 faciliteert het onderzoek; $4=$ grote meenwaarde $5=$ vrijweil onmisbar $: 6=$ onmisbaar. 
In 17 (16\%) van de onderzoekverslagen wordt aangegeven welke statistische bewerkinget zijn toegepast op de gepubliceende data. In geen enkele publicatie wordt verneld of hierbif gebruk is gemaakt van een computer en een computerprogramma voor statistische data-analyse.

Tabel 3.4 Samewating van tabel 32 ; beordeling van de meenwarde van automatisering uitgedruki in categorieën (datawerzameling in centrale computeraangegeven ussen havkjes) geordend volgens publicatiejaur (periode).

\begin{tabular}{llccrr}
\hline $\begin{array}{c}79-81^{*} \\
n=10\end{array}$ & $\begin{array}{c}82-83 \\
n=16\end{array}$ & $\begin{array}{l}84-85 \\
n=31\end{array}$ & $\begin{array}{c}86-89 \\
n=26\end{array}$ & $\begin{array}{l}88-89 * * \\
n=22\end{array}$ \\
\hline 1 & & & & & \\
2 & 3 & 2 & 6 & 4 & $4(1)$ \\
3 & 2 & $10(1)$ & $13(2)$ & $10(5)$ & $10(5)$ \\
4 & $3(1)$ & $3(3)$ & $7(5)$ & $7(5)$ & $6(5)$ \\
5 & $2(1)$ & 1 & 3 & $5(1)$ & $2(2)$ \\
6 & - & - & $2(2)$ & & \\
\hline
\end{tabular}

* october $1979 \mathrm{t} / \mathrm{m}$ december 1981 * januari $1988 \mathrm{t} / \mathrm{m}$ september 1989.

Tabel 3.5 Samenvating van data in tabel 3.2: gebruik van centrale computer-faciliteiten per periode.

\begin{tabular}{lccc}
\hline $\begin{array}{l}\text { Periode waarin } \\
\text { onderzoek werd } \\
\text { gepublicaerd }\end{array}$ & $\begin{array}{c}\text { Aantal } \\
\text { geanalyseerde } \\
\text { publicaties } \\
\mathbf{n = 1 0 5}\end{array}$ & $\begin{array}{c}\text { Gebruik van } \\
\text { centrale } \\
\text { computer } \\
\mathbf{n = 3 9}\end{array}$ & $\begin{array}{c}\text { Percentage } \\
\text { met gebruik } \\
\text { van centrale } \\
\text { computer }\end{array}$ \\
\hline $1979-1981^{*}$ & 10 & 2 & 20 \\
$1982-1983$ & 16 & 4 & 25 \\
$1984-1985$ & 31 & 9 & 29 \\
$1986-1987$ & 26 & 11 & 42 \\
$1988-1989^{* *}$ & 22 & 13 & 65 \\
\hline
\end{tabular}

* october $1979 \mathrm{t} / \mathrm{m}$ december 1981 ; * januari $1988 \mathrm{t} / \mathrm{m}$ september 1989.

Tabel 3.6 Toepassing van literatiur-search wia de computer wordt waarschijnlij geacht.

\begin{tabular}{|c|c|c|c|}
\hline $\begin{array}{l}\text { Periode waarin } \\
\text { onderzook wird } \\
\text { gopubllceerd }\end{array}$ & $\begin{array}{c}\text { Aantal } \\
\text { geanalysearde } \\
\text { publicaties } \\
n=105\end{array}$ & $\begin{array}{c}\text { Indicatie } \\
\text { literatuursearch } \\
\text { via computer } \\
n=20\end{array}$ & $\begin{array}{l}\text { Percentage } \\
\text { met indicatie } \\
\text { litteratuursearch } \\
\text { via computer }\end{array}$ \\
\hline 19791981 & 10 & 3 & 30 \\
\hline $1982-1983$ & 16 & 0 & 0 \\
\hline $1984-1985$ & 31 & 4 & 13 \\
\hline $1986-1987$ & 26 & 5 & 19 \\
\hline $1988-1989 *$ & 22 & 8 & 36 \\
\hline
\end{tabular}

* october 1979 t/m december 1981; * 2januari 1988 t/m september 1989. 
Figum 3.1 toont een grafische representatie van de diverse parameters. Tabel 3.7 geeft weer hoe de beoordeling van de verwachte meerwaarde van de automatisering zich verhoudt tot de overige bestudeerde variabelen.

Figuur 3.1 Toepassing automatisering bij onderzoek. Conclusie naar aanleiding van 105 anderzoekverslagen (beoordeling door de onderzoeker).

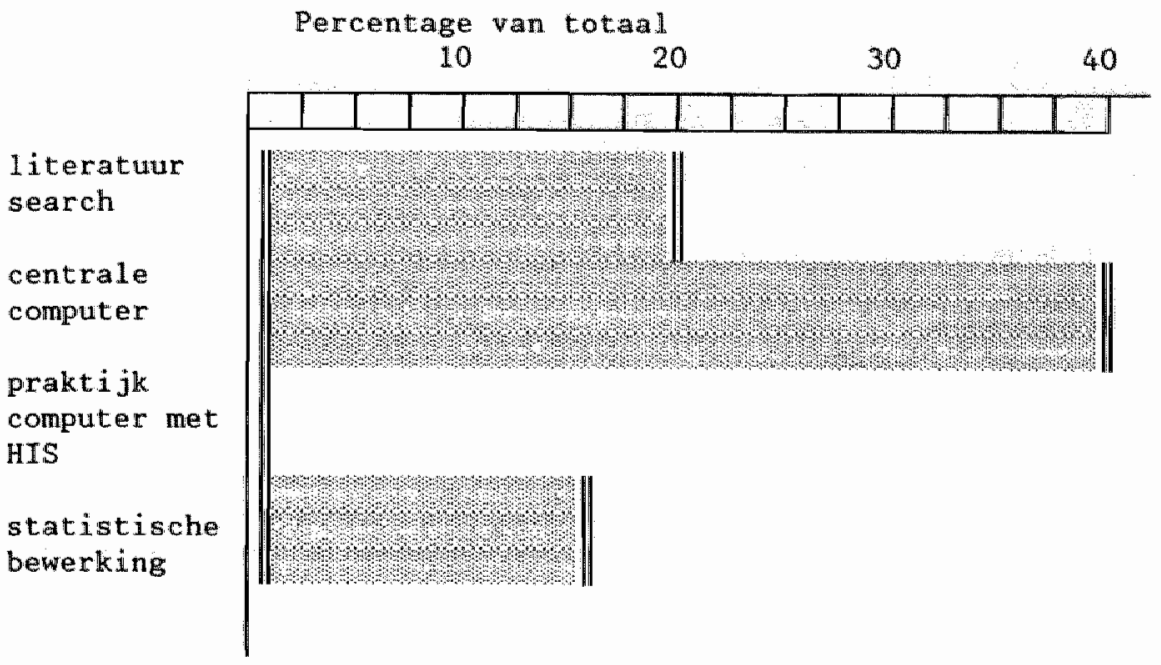

Tabel 3.8 Beoordeling van de verwachte meerwaarde van de automatisering vergeteken met de andere bestudeerde parameters

Beoordeling van
reële toepassing:

Beoordeling te verwachten meorwaarde (caategorlounl

$\begin{array}{cccccc}1 & 2 & 3 & 4 & 5 & 6 \\ n=0 & n=19 & n=46 & n=25 & n=13 & n=2\end{array}$

Aanwijzing voor verrichte literatuursearch $(\%)$

nn.v.t 10

22

16

31

0

Aangegewen gebruik

centrale computer $(\%)$

n.v.t. 5

28

76

31

100

Vermelding statistische

databewerking $(\%)$

n.w.t 5

11

32

8

100

Tabel 3.8 geeft een overzicht van de resultaten van de telefonische enquête: uit de cijfers betreffende het item "statistiek" blijkt dat de dokters in het algemeen "meer doen dan ze zeggen'. De kappawaarde voor de beoordeling van de statistische bewerking bereikt ove- 
Tabel 3.7 Uithomsten van de telefonische enquête bij 13 van de 105 auteurs van bestudeerde onderzodwerslagen.

\begin{tabular}{|c|c|c|c|c|}
\hline & $\begin{array}{l}\text { Literatuur } \\
\text { search }\end{array}$ & $\begin{array}{l}\text { Dataverzameling } \\
\text { aan de bron } \\
\text { bij de huisarts }\end{array}$ & $\begin{array}{l}\text { Gebruik centrale } \\
\text { compurter }\end{array}$ & $\begin{array}{c}\text { Statistische } \\
\text { bewerking van } \\
\text { de data }\end{array}$ \\
\hline Owerdenstmming & $n=9$ & $n=13$ & $n=8$ & $n=11$ \\
\hline $\begin{array}{l}\text { Vermeld/toegepast } \\
\text { Niet vermeld/niet }\end{array}$ & 1 & 0 & 3 & 3 \\
\hline toegepast & 8 & 13 & 5 & 8 \\
\hline Verschinil & $n=4$ & $n=0$ & $n=5$ & $n=2$ \\
\hline $\begin{array}{l}\text { Vermeld/niet } \\
\text { toegepast } \\
\text { Niet vermeld/wel }\end{array}$ & 2 & 0 & 2 & 0 \\
\hline toegepast & 2 & 0 & 3 & 2 \\
\hline Kappa & 0.23 & $*$ & 0.22 & 0.65 \\
\hline
\end{tabular}

Toelichting 'vermeld'verwijst naar de beoordeling op grond van het gepubliceerde onderzoekverslag: 'toegepast' verwijst naar de mededeling van een van de auteurs bij de telefonische of mondellinge enquête.

* Niet te berekenen.

rigens een redelijk niveau terwijl de overeenstemming voor de dataverzameling bij de bron maximaal is.

\subsection{Beschouwing}

Anallyse van een aantal in Huisarts en Wetenschap gepubliceerde onderzoekverslagen laat duidelijk zien, dat er vooral de laatste jaren in toenemende mate gebruik wordt gemakt van grote databestanden, opgeslagen in een centrale computer. Het gebruik van

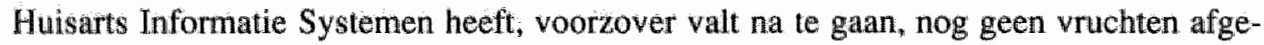
worpen voor de wetenschap. Slechts bij én onderzoek wordt vermeld dat er gebruik is gemaakt van een geautomatiseerd adressenbestand. In een aantal verslagen wordt vermeld dat "de praktijkpopulatie niet afwijkt van de standaardpopulatie". Deze vooronderstelling wordt dan vervolgens niet met harde gegevens onderbouwd.

Bij het bespreken van de resultaten is al vermeld, dat nergens is terug te vinden hoe de auteurs precies zijn gekomen aan hun literatuur. Het ligt voor de hand dat de meeste au* teurs van recente publicaties iets verder hebben gekeken dan de eigen boekenkast en het eigen kaartsysteem en vaak well de computer van de (universiteits)bibliotheek hebben geraadpleegd. Toch laten de publicaties zich hierover niet uit. Bij de telefonische enquête bleek een verschil te bestaan tussen de conclusie "indicatie voor toepassing van literatuur-search" en de feitelijke uitvoering van de literatuurverzameling door de auteurs ( $t a-$ 
bel 3.8). De gebruikte onderzoekmethode (beoordeling volgens de beschreven puntenschaal) blijkt niet te voldoen. Dit heeft geen betekenis voor een conclusie wat betreft de meerwaarde van het gebruik van de computer bij literatuuronderzoek.

De laatste jaren zijn in elke uniwersiteitsbibliotheek faciliteiten beschikbaar voor literatuursearch via de computer. Daarnaast is een aantal grote literatuur-bestanden tegenwoordig direct on-line toegankelijk woor geautomatiseerde huisartsen. ${ }^{11}$ De kwaliteit én de volledigheid van literatuurreferenties kunnen toenemen wanneer op deskundige wijze een computersearch wordt uitgevoerd. Dit is zeker het geval wanneer de referenties van de in eerste instantie gevonden onderzoeksartikelen hierbij worden betrokken. ${ }^{112}$

Het is aannemelijk dat in het huidige computertijdperk nog maar weinig statistische bewerkingen worden uitgevoerd met een rekenlineaal of calculator. Bij veel onderzoek in het verleden, ook bij grotere projecten, is dit kennelijk wel zo gegaan (zie tabellen $3.7 \mathrm{en}$ 3.8 ).

Veel onderzoekers vermelden niet welke statistische onderzoekmethoden en/of programmatuur op de data werden losgelaten. 'Chi-kwadrat' klinkt al een stuk beter dan 'dank aan Hans voor de statistische bewerking', maar is ook nog onvoldoende. De kritische lezer weet dat er goede en minder goede statistische software is. ${ }^{113}$ Toch wordt in geen enkele publicatie vermeld met welk statistisch softwareprogramma de data zijn bewerkt. De auteurs hebben kennelijk een onbegrensd vertrouwen in de statistische tovenaar en zijn toverstok, de toegepaste software.

Een opsomming van de meest frequent gebruikte onderzoek-modellen in tabel 3.3 (categorieën 3 en 4), geeft meteen een antwoord op de twee laatste vragen, die geformuleerd werden bij de aanvang van dit literatuuronderzoek.

Het blijkt dat de vermelde onderzoekmethoden, met name het gebruik van centrale bestanden als een index die verwijst naar patiënten in de huisartspraktijk (categorie 4 ), steeds vaker toegepast worden. Vrijwel altijd wordt hierbij gebruik gemaakt van een grote centraal opgestelde computer. Dit betekent dat een dergelijk onderzoek vrijwel alleen mogelijk is, indien de onderzoekers werken onder de paraplu van een groot onderzoekproject. In het volgende hoofdstuk wordt hier nader op ingegaan.

Bij de meer eenvoudige onderzoeken, in tabel 3.3 als cluster ondergebracht in categorie 3 , is vooral het retrospectieve kaartenbak-onderzoek nog erg populair. Waarschijnlijk zal dit nog lang zo blijven, want het is een onderzoekmethode die zeer dicht bij de huisarts staat.

Meyer vermeldt als negatieve aspecten o.a. het 'loket-effect', de 'observerbias' en de vele interpretatieproblemen veroorzaakt door gebrekkig bijgehouden en moeilijk leesbare patiëntenkaarten. ${ }^{18}$ Automatisering van de medische administratie (journaal en probleemlijst) zal hier veel aan kunnen veranderen, zodat de betrouwbaarheid van deze onderzoekmethode zal toenemen. Wel zal, om met Meyer te spreken, aan de factor 'huisarts' retro" spectief niets veranderd kunnen worden.

De meerwaarde van een praktijkcomputer en HIS met een geautomatiseerd "sex-age' register en liefst ook een geautomatiseerde 'groene kaart' komt goed naar voren, wanneer een praktijk participeert in onderzoek.

De investeringen in kosten en tijd wegen dan ruimschoots op tegen de winst in tijd, kwaliteit (denk alleen al aan de leesbaarheid) en bereikbaarheid van de onderzoekdata. 
Het onder 5 gerangschikte onderzoek is nog steeds mogelijk zonder computer, zoals blijkt unt enkele publicaties uit 1989.107109 Het getd en de tijd die verspild worden aan het witpluizen van de kartenbak kunnen beter besteed worden voor de aanschaf van een prakijikcomputer en implementatie van de praktijkautomatisering. Hiena is hell geen "monnikenwerk" meer om én of meer keren de kaartenbak door te zoeken.

Het onder categorie 6 gerubriceerde onderzoek is vrijwel alleen mogelijk indien men beschikt over centralle computerfachliteiten. Registratie van patiêntgegevens in de computer van de huisarts biedt ook hier voordelen: geautomatiseerde controle op volledigheid wan de aangeleverde data aan de bron en rechtstreekse overdracht van de gegevens naar de centrale computer.

\subsection{Conclusile}

Een analyse van 105 onderzoekverslagen die gedurende de afgelopen 10 jaar werden gepubliceerd in het tijdschrift Huisarts en Wetenschap leidt tot de conclusie, dat bij huisartsgeneeskundig onderzoek in toenemende mate gebruik wordt gemaakt van gegevensopslag en gegevensbewerking in centrale computerbestanden. Uit de geanalyseerde data blijkt niet dat de computer ook een duidelijke functie heeft bij het opzoeken van literatuurreferenties en bij de statistische bewerking van de onderzoekgegevens. De computer kan hierbij echter een belangrijke rol spelen, indien aan twee voorwaarden wordt voldaan:

- in literatuurbestanden moet voldoende huisartsgeneeskundige literatuur aanwezig zijn " die bovendien goed en gemakkelijk toegankelijk is;

- de statistische pakketten moeten goed toegesneden zijn op wetenschappelijk onderzoek in de huisartspraktijk.

Kleine, door de huisarts zelf in een Huisarts Informatie Systeem opgebouwde databestanden, spelen nauwelijks een rol bij de dataverzameling voor wetenschappelijk onderzoek in de huisartspraktijk zelf of in het kader van onderzoeken waaraan meerdere huisartsen deelnemen (zie figuur 3.1).

Vermoedelijk zal de snel voortschrijdende automatisering van de huisartspraktijk ertoe leiden, dat dil 'gat' de komende jaren gedicht zal worden.

De resultaten van deze literatuuranalyse leiden tot een positieve uitspraak over de te verwachten meerwaarde van de praktijkautomatisering bij een aantal typisch huisartsgeneeskundige onderzoekmethoden.

\section{Literatuur}

1 Difford F. Mapping practice population and morbidity with a computer. Br Med J $1985 ; 291: 1017-20$.

2 Hall GC, Luscombe DK, Walker SR Post-marketing surveillance using a computerised General Practice data base. Pharmaceut Med 1988;2:345-51.

3 Smits A, Mokkink H, Grol R. Spreekuurgedrag van huisartsen. Huisarts Wet 1985:28:121-5.

4 Haan $M$ de. Vage klachten. Wat verstaan patiënten en huisartsen eronder? Huisarts Wet $1982 ; 25: 190-5$. 
5 Tielens $\mathrm{V}$. Het medisch diagnostisch handelen van de huisarts. Huisarts Wet $1985 ; 28: 53-8$.

6 Adarn WL, Cate RS ten. De visite in de huisartspraktijk. Huisarts Wet 1979:22:488-92.

7 Geus CA de, Nix EC, Schimmel H, Siemons G, Spoelstra W. Samenwerking tussen huisarts en psycholoog. Huisarts Wet 1980;23:3-7.

8 Bremer GJ. Over het gebruik van de huisartsen-anamneselijst bj vage, onduidelijke klachten. Huisarts Wet 1980;23:53-8.

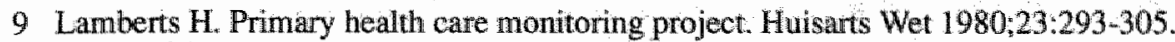

10 Seelen AMR, Diederiks JPM, Zutphen WM van, Sikkens T. Identification of cardiovascular risk factors in a general practice. Huisarts Wet 1980,23:325-31.

11 Ploeg HM van der: Persoonlijkheidskenmerken en huisartscontact-frequentie. Huisarts Wet 1980:23:398-403.

12 Koningsveld B van, Weyenburg HM. Nabestaan, een naar bestaan. Huisarts Wet $1980 ; 23: 431-4$.

13 Crebolder HFIM. Over sterven en stervensbegeleiding. Huisarts Wet 1980;23:439-46.

14 Weel C van, Tielemans W. Diabetes mellitus in een huisartspraktijk. Huisarts Wet $1981 ; 24: 13-17$.

15 Bekker JP, Prins A. Bloeddrukdaling na interventie door de huisarts. Huisarts Wet 1981;24:177-82.

16 Crul BVM. De invloed van de huisarts op het kortdurend ziekteverzuim. Huisarts Wet $1982 ; 25: 103-5$.

17 Knotmerus JA, Sommers JCA. Werken en niet kunnen werken. 2. Werk voor de huisarts? Huisarts Wett 1982;25:186-90.

18 Meijer JS. De diagnose irritable bowel syndroom in de huisartspraktijk. Huisarts Wet 1982;25:274-8.

19 Feen JAE van der. Zes jaar later. Huisarts Wet 1982;25:389-93.

20 Weel $\mathrm{C}$ van. De voor hypertensie behandelde populatie in de huisartspraktijk. Huisarts Wet $1983 ; 26: 4-8$

21 Crebolder HFJM. Gebruik en gebruikers van fysiotherapeutische behandelingen. Huisarts Wet 1983;26:42-8.

22 Roolvink EGJJ. Registratie van kanker in een huisartspraktijk. Huisarts Wet 1983;26:84-87.

23 Prins A. Enkele aspecten van hypertensiebestrijding door de huisarts. Huisarts Wet 1983:26:93-5.

24 Meyboom WA. De beperkingen van cardiofonie. Huisarts Wet 1983;26:136-9.

25 Meijman $\mathbb{E}$, Nemere S, Waal JCS van der, Ketting E. Anticonceptie en kinderwens. Huisarts Wet 1983:26:172-80.

26 Weel $\mathrm{C}$ van, Zelst PAM van. Diabetes mellitus in een huisartspraktijk II. Huisarts Wet 1983:26:214-7.

27 Cottaar M, Doom H van, Lansink Th, ea. Röntgenonderzoek in de huisartspraktijk. Huisarts Wet 1983;26:373-5.

28 Thomassen JFM, Nood D de. Communicatie en compliantie. Huisarts Wet $1983 ; 26: 376-80$.

29 Damstra-Wijmenga SMI. Veilig bevallen: thuils of (poli)klinisch Huisarts Wet 1983;26:403-6.

30 Hirschfeld $\mathrm{H}$. Het pessarium occlusivum: een achterhaalde vorm van anticonceptie? Huisarts Wet 1983;26:407-10

31 Bosch WJHM van den. Het pessarium als behandeling woor prolaps van de vagina. Huisarts Wet 1983;26:411-3.

32 Terluin B. Het hyperventilatiesyndroom in een huisartspraktijk. 1. Een beschrijving van 78 patiënten. Huisarts Wet $1984 ; 27: 4-11$.

33 Terluin B. Het hyperventilatiesyndroom in een huisartspraktijk. 2. Een evaluatie van de behandeling van 74 patiënten. Huisarts Wet 1984;27:82-7.

34 Lamberts H, Meads S, Wood M. Waarom gaat iemand naar de huisarts? Huisarts Wet 
$1984 ; 27: 234,44$

35 Meyboom WA, Post D, Thomas S. Het voorschrijven van geneesmidelen aan kleine kinderen. Huisarts Wet $1984,27,300-2$.

36 Wal $\mathrm{G}$ van der, smeenk CJ. Bewerkelijheid nader bekeken. Huisarts Wet $1984 ; 27: 309-10$.

37 Akkeren van, Veeninga T. De behandeling van patiènten met chronisch klaaggedrag in een huisartspraktijk. Huisarts Wet 1984;27:342-4.

38 Hatan $M$ de. Turkse, Marokkaanse en Nederlandse jongeren in een Amsterdamse huisartspraktijk. Huisarts Wet 1984;27:345-8.

39 Brak EM ter, Werf G TH van Verwizen of niet? Huisarts Wet 1984;27:334-7.

40 Breijer MTH, Lamberts H. Hoe kiest de patient zijn huisarts? Huisarts Wet $1984 ; 27: 338-41$.

41 Meijman F. Twalf jaar cervixcytologie in drie Amsterdamse huisartspraktijken. Huisarts Wet 1984:27:372-8.

42 Weel $C$ van. Screenen door huisartsen op cervixcarcinoom. Huisarts Wet $1984 ; 27: 379: 82$.

43 Schellekens JWG, Hoogen IMM van, Woestijne P van de, et al. Leefijd en morbiditeit. Huisarts Wet 1984;27:435-40.

44. Wal G van der, Smeenk RCJ, Wempe PA. Vijf jaar spiraaltjes in een huisartspraktijk. Huisarts Wet 1985;28:5-10.

45 Ree IW van, Gerwen W van, Hoogen H van den. Interventie bij een verhoogd risico op hart en vatziekten. 1. Resultaten op langere termijn van interventie bij hypercholesterolemie, adipositas en roken. Huisarts Wet $1985,28: 21-4$.

46 Knook H. Radiogram van een vrije westiging. Huisarts Wet 1985;28:58-60.

47 Ree JW van, Gerwen W van, Hoogen H van den. Interventie bij een verhoogd risico op hart- en vaatziekten. 2 . Resultaten op langere termijn bij de behandeling van hypertensie. Huisarts Wet 1985;28:53-8.

48 Roelfsema WJ. Begeleiding van kankerpatiènten door de huisarts. Huisarts Wet $1985 ; 28: 92-3$.

49 Bosch W van den. Het Lentse dodenboekje. Huisarts Wet 1985;28:99-104.

50 Zee B van der. Oudere patiênt en psychosociale problematiek. Huisarts Wer $1985 ; 28: 126-8$.

51 Knotnerus IA, Ebbens E, Govaert THME, Geus CA de. Klachten op de borst: omgaan met onzekerheden. Huisarts Wet 1985;28:159-63.

52 Baselier PJAM. Recidiverende acute bacteriële urineweginfecties in de huisartspraktijk. Huisarts Wet 1985;28:164-7.

53 Weel $C$ van. Screenen door huisartsen op cervixcarcinoom. Huisarts Wet $1985 ; 28: 242-3$.

54 Mesker-Niesten J, Nadorp D, Nolet H, Prick-Slothouwer M. Ervaringen wan IUD-gebruiksters. Huisarts Wet 1985;28:244-6.

55 Duijn NP van, Haan J de, Kanis W. Een onderzoek naar het bestaan van een spaanplaatsyndroom. Huisarts Wet 1985:28:260-3.

56 Post D, Gubbels J. Hoofdpijn in een huisartspraktijk. Huisarts Wet 1985;28:264-6.

57 Slegt AC, Kessel-Al HA, Brouwer HJ. Ziektegedrag van allochtone patienten. Huisarts Wet 1985:28:289-93.

58 Esser $C J$, Weel $C$ van. Het beloop van uitstralende rugpijn. Huisarts Wet 1985;28:335-7.

59 Verkes RJ, Megchelen PJ van. Nek- en nugpijn bij gevoelens van agressie en onmacht. Huisarts Wet 1985;28:331-4.

60 Bosch W van den. Kanker in vier huisartspraktijken. Huisarts Wet 1985;28:356-61.

61 Meijden WI van der, Bosch I, Haes WFM de, Lako Cl et al. Vaginale afscheiding: wat zeggen vrouwen er zelf over? Huisarts Wet 1985;28:387-91.

62 Bergenhenegouwen NGPM. Melkzuurspoelingen bij vaginitis. Huisarts Wet $1985 ; 28: 398 \times 9$.

63 Meyboom-de Jong B, Postma TE, Ende J van der, Lamberts H. De functionele toestand 
van patuenten. Huisarts Wet 1986;29:11-4.

64 Tempelaar AF. Sterfte en iatrogene schade. Huisarts Wet 1986,29,34-7

65 Lagro-Janssen T. Nooit op tijo. Huisarts Wet 1986,29:38-40.

66 Lagro-Janssen $T$, Manen M van. Ales weggehaald... 1. Een onderzoek naar de relatie tussen uterusextirpatie en medische consumptie. Hussarts Wet 1986,29:137-40.

67 Lagro-Janssen T, Frenay I, Arendonk M van. Alles weggehaald... 2. Een onderzoek naar enkele kenmerken van vrouwen die een uterusextirpatie hebben ondergaan. Huisarts Wet 1986;29:168-71.

68 Mens J. Moeders woor snoepers? Huisarts Wet $1986 ; 29: 1724$.

69 Avezaat JJM, Lutjentuis MTH. Ulcus pepticum bij allochtone Nederlanders. Huisarts Wet 1986;29:218-9.

70 Tillema W. Hoe vergaat het de patiènt na cardiofonie? Huisarts Wet 1986:29:233-6.

71 Terluin B. Surmenage in een huisartspraktijk. Huisarts Wet 1986,29:261 -4.

72 Meijman F. Cervixcytologie via een actieve benadering. Huisarts Wet 1986;29:336-8.

73 Kuyvenhoven MM, Melker RA de. Verwijzingen naar interne en chirurgische specialismen. Huisarts Wet 1986;29:365-8.

74 Wevers $C W J$, Leden $J$ van der. De hulp van de huisarts aan ouderen. Huisarts Wet 1987;30:3-8.

75 Knottnerus JA, Starmans R, Vissers A. Diagnostische conclusies van de huisarts naar aanleiding van onverklaande moeheid. Huisarts Wet 1987:30:9-12.

76 Aulbers BJM. Voetklachten in een huisartspraktijk. Huisarts Wet 1987;30;38-40.

77 Lagro-Janssen T. Een plaats om te sterven... voor man en wrouw gelijk? Huisarts Wet 1987;30:101 4.

78 Lamberts H, Brouwe H, Groen ASM, Huisman H. Het transitiemodel in de huisartspraktijk. Huisarts Wer 1987;30:105-13.

79 Meijman FJ. Gynaecomastie bij jong volwassenen. Huisarts Wet 1987;30:138-40.

80 Meijman FJ. Geregistreerde problemen tijdens 3608 pilcontroles. Huisarts Wet $1987 ; 30: 170-3$.

81 Prins A, Roelofs R. Zeven jaar later. Huisarts Wet 1987;30:210-11.

82 Hoogen JPH van den, Haverkort AFM, Leur J de, Ree JW van. Een semi-geautomatiseerd hypertensiebewakingssysteem in de haisartspraktijk. Huisarts Wet $1987 ; 30: 240-3$.

83 Verbeek AC. Polymyalgia theumatica acuta en arteriitis temporalis in een huisartspraktijk. Huisarts Wet 1987;30:263-7.

84 Muris JWM, Vaessen MHJ, Sturmans F. De waarde van auscultatie bij de diagnostiek van bronchusobstructie in de huisartspraktijk. Huisarts Wet 1987;30:272-4.

85 Meyboom WA. Digoxine in een huisartspraktijk. Huisarts Wet 1987;30:303-7.

86 Eijk $J$ van, Huygen $F$, Hoogen $H$ van den. Veranderingen in het morbiditeitspatroon van nabestaanden. Huisarts Wet 1987;30:336-9.

87 Meijman FI. AIDS-problematiek in twee Amsterdamse huisartspraktijken. Huisarts Wet $1987 ; 30: 340-1$.

88 Smits A, Grinten $\mathrm{R}$ van der, Huygen $\mathrm{F}_{4}$ Hoogen $\mathrm{H}$ van den. 'Ze stuurden me naar de dokter'. Huisarts Wet 1987:30:377-80.

89 Vliet LAM van, Dekker FW, Mulder Dzn JD. De pilcontrole afgeschaft, opluchting of gemis? Huisarts Wet 1988;31:7-10.

90 Aussems JH, Alting von Geusau WAM, Smits AJA. Huisarts en incest. Huisarts Wet $1988 ; 31: 48-50$.

91 Meurs JJW, Verbeek-Heida PM. Compliantie bij antibiotica. Huisarts Wet 1987;30:67-9.

92 Rutten GELM, Eijk JTM van, Beek MML, Velden HGM van der. De type-Il diabeet: hoe staat het ermee? Huisarts Wet 1988;31:124-9.

93 Plagge HWM, Vissers. FHJA, Pouls K, Geus de CA. Het voorschrijven van geneesmiddelen zonder arts-patiënt contact. Huisarts Wet 1988;31:120-23

94 Rempt E, Ponsioen BP. Ouders van kinderen met CARA onderwraagd. Huisarts Wet $1988 ; 31: 165-6$. 
95 Tempelarar Af, Haajer-Ruskamp FM, Pennink BJ, et al. Langdurig gebruik van beta-blokkers en de kwallteit van het leven. Huisants Wet 1988;31:189-95.

96. Lisdonk EH van de. Klachten zonder klagen bil de dokter. Huisarts Wet $1988 ; 31: 257-60$.

97 Wielink $\mathrm{G}$. Opname wegens een hypoglykemisch coma Huisarts Wet 1988;31:264-5.

98 Reenders $\mathrm{K}$, Nobel $\mathrm{E} \mathrm{de}$, Weel $\mathrm{C}$ van. Diabetes melitus in een groepspraktijk. 1 . Diagnostiek, controle en behandeling. Huisarts Wet 1988;31:327-30.

99 Reenders $\mathrm{K}_{\mathrm{s}}$ Nobel $\mathrm{E}$ de, Weel $\mathrm{C}$ van. Diabetes mellitus in een groepspraktijk. 2.Complicaties. Huisarts Wet 1988;31:359-63.

100 Lagro-Janssen T. Eenmaal een niersteen, altijd een niersteen? Huisarts Wet 1989,32:4-6.

101 Dieleman FE, Dekker FW, Kaptein AA. Compliantie bij astma-medicatie. Huisarts Wet 1989;32:43:7.

102 Rens $\mathrm{HAJ}$ van, Comel $M$, Zutphen WM van. Herkenning van problematisch alcoholgebruik in de huisartspraktijk. Huisarts Wet 1989;32:48-50.

ل03 Jol $A_{*}$ Verhaak PFM. Psychische en sociale klachten: gespreksvoering of psychofarmaca? Huisarts Wet 1989;32:89-95.

104 Bremer GI. Een onderzoek naar verwijsbrieven. Huisarts Wet 1989;32:100-1.

105 Francheboud J, Berkel J, Bonjer FH, Collette HJA. Thuisbehandeling na een acuut hartinfarct: hoe vaak en welke patiënten? Huisarts Wet 1989;32:162-4.

106 Bosch W wan den, Weel C van. Leeftijd- en geslachtsverschillen bij fracturen en andere traumata. Huisarts Wet 1989:32:246-8.

107 Walma EP, Boukes FS, Prins A, Does E van der. Diureticagebruik door 65-plussers in een huisartspraktijk. Wie kunnen er stoppen? Huisarts Wet 1989;32:326-8.

108 Krebber Th, Brouwer W, Greep J, Hoogenband C, Knottnerus JA. Acute buikpijn op een EHBO. Huisarts Wet 1989;32:329-33.

109 Haan M de. Indicatoren voor CARA bij kinderen. Een transversaal onderzoek onder 6-11 jarigen in vijf Nederlandse huisartspraktijken. Huisarts Wet 1989;32:334-7

110 Meyboom-de Jong B, Smith $\mathbb{R} J A$. Cerebrovasculaire stoornissen bij ouderen in de huisartspraktijk. Huisarts Wet 1989:32:359-65

111 Volkers ACW, Tjiam IAS, Nelemans-Van den Broek EADM, Bleeker A. Literatuuronts]uiting en -opslag door bibliotheekgebruikers met behulp van een microcomputer. Ned Tijdschr Geneeskd 1989;133:294-7.

112 Hofmans EA. De opbrengst van een Medline-search. De toegankelijkheid van onderzoek naar de effectiviteit van acupunctuur II. Huisarts Wet 1990;33:103-6.

113 Dallal GE. Statistical microcomputing - Like it is. The American Statistician $1988 ; 42 ; 212-6$. 


\section{Huisartsgeneeskundige registratiesystemen}

Samenvatting Dit hoofdstuk geeft een overzicht van huisartsgeneeskundige registratiesystemen in Nederland. Besproken worden: doelstelling, geschiedenis, huidige samenstelling van de groep onderzokers, inhoud van de registratie en methode van registratie. Speciaal aandachtspunt is het gebruik van de praktijkcomputer bij data-entry. Er blijken zeer grote verschillen te bestaan in doelstelling en werkwijze van de verschillende registratiesystemen. Bij slechts drie van de megen beschreven registratieprojecten wordt de praktijkcomputer gezien als een belangrijk hulpmiddel bij het vastleggen van de onderzoekgegevens.

\subsection{Inleiding}

Er zijn in Nederland nogal wat ziektegerichte en zorg georiënteerde registraties. Bij de bespreking hiervan worden huisartsgeneeskundige registraties vaak onderbelicht. ${ }^{2}{ }^{2}$ Een aantal van deze projecten heeft duidelijk een stimulerende invloed gehad op huisartsen die erbij betrokken waren. $\mathrm{Zij}$ hebben vaak gebruik gemaakt van de centraal opgeslagen data om een selectie patiënten uit de eigen praktijk op te zoeken en dan verder onderzoek te verrichten met deze subpopulatie. Daarnaast wordt in de literatuur nog steeds en frequent verwezen naar morbiditeitsgegevens, die afkomstig zijn uit én of meer van deze projecten; met name betreft het hier gegevens uit het Monitoring project en de permanent bijgehouden gegevens van de Continue Morbiditeitsregistratie in Nijmegen ${ }^{3}{ }^{4}$

In dit hoofdstuk wordt een overzicht gegeven van een aantal Nederlandse huisartsgeneeskundige registratieprojecten. Voor een historisch overzicht wordt verwezen naar eerdere publicaties over dit onderwerp. ${ }^{56}$

Bij het beschrijven van de verschillende projecten zal vooral aandacht gegeven worden aan de gebruikte methode van data- verzameling en de rol die de automatisering daarbij al speelt of moet gaan spelen in de toekomst. Dit moet leiden tot een antwoord op de volgende vragen:

- Welke stadia van dataverzameling (bron, transport, centrale opslag en verwerking) zijn al geautomatiseerd?

- Is er een tendens te bespeuren naar dataverzameling aan de bron via een praktijkcomputer met een HIS?

Dit hoofdstuk is tot stand gekomen in nauwe samenwerking met J.F.M. Metsemakers, die in zijn eigen dissertatie (in bewerking) nader zal ingaan op de methodologische aspecten van dataverzameling en controle bij de beschrewen huisartsgeneeskundige registratiesystemen. 


\subsection{Methode}

Een aantal omvangrijke huisartsgeneeskundige registratieprojecten die al geruime tijd actief zijn werd nader onderzocht. Tevens werd gekeken nar enkele registratieprojecten die nog in de opbouwfase verkeren.

Alleen continute en longitudinale registratieprojecten die gegevens registreerden van meerdere praktijkpopulaties werden bij dit onderzoek betrokken. Daarom werd bijvoorbeeld de Nationale morbiditeitsstudie wan het Niwel niet vermeld.

De publicaties wanuit deze projecten of ower deze projecten werden geanalyseerd. Een samenvatting en overzicht van de conclusies werden vervolgens toegestuurd aan de contactpersonen van de werschillende registratie- netwerken. Daarbij kregen zij ook nog een lijst meil aanvullende vragen, die vooral betrekking hadden op de actuele stand van zaken (peilldatum 30-11-1989).

De resterende onduidelijke punten werden opgehelderd via telefonisch contact of in een persoonlijk gesprek met de projectleiding. Daarnaast werden zo nodig enkele registrerende huisartsen telefonisch of mondeling benaderd voor aanvullende informatie.

\subsection{Nederlandse huisartsgeneeskundige registratiesystemen}

De verschillende registratiesystemen worden in volgorde van anciënniteit besproken in dit hoofdstuk. Tabel 4.1 laat de overeenkomsten en verschillen zien in een vergelijkend overzicht. Bij alle beschreven registratieprojecten worden de verzamelde data opgeslagen in een centraal computerbestand.

\section{Pellstations infectieziekten van de GGD in Rotterdam ${ }^{7}$}

Doel

Geschiedenis

Huidige samenstelling Basispopulanio
Monitoring van de locale morbiditeit ten behoeve van de afdeling infectieziekten en hygiëne van de GGD in Rotterdam. 1965: start van het registratieproject met 13 huisartsen en 5 dermatologen.

18 huisartsen, 10 dermatologen.

omvang op peildatum niet bekend

Tabel 4.11 Overicht wan het gebruik wan de computer in de verschillende stadia van dara. verameling bij de besproken registratieprojecten.

\begin{tabular}{llllllllll} 
Pegistratio & \multicolumn{7}{c}{ Registratieproject } \\
& 1 & 2 & 3 & 4 & 5 & 6 & 7 & 8 & 9 \\
\hline Bron & - & - & - & - & - & - & + & $(+)$ & $(+)$ \\
Transport & - & - & - & - & - & - & + & $(+)$ & $(+)$ \\
Centralle opslag & + & + & + & + & + & + & + & $(+)$ & $(+)$ \\
Verwerking & + & + & + & + & + & + & + & $(+)$ & $(+)$
\end{tabular}

(4) in de toekomst. 
Inhoud registratie

Methode van registratie

Praktijkautomatisering Niet toegepast.

\section{Continue Morbiditeitsregistratie Nijmegen ${ }^{4} 89$}

Doel

\section{Geschiedenis}

Huidige samenstelling

Basispopulatie

Inhoud registratie

Methode registratie

Praktijkautomatisering loop-geneeskunde'. praktijken

Circa 12.000 kenmerken;

Alle nieuwe morbiditeit;

Opnamen in ziekenhuis. stemde formulieren.

Alleen infectieziekten: 15 items per jaar.

De peilstation praktijken houden op een 'weekstalat' bij hoe vaak ze één van de 15 te vervolgen infectieuze aandoeningen bij patiënten hebben geconstateerd. Deze formulieren worden op het eind van de week naar de GGD gestuurd.

Centrale data-opslag en verwerking per computer.

Dataverzameling ten dienste van onderwijs en onderzoek.

1 Het geven van een morbiditeitsspectrum in de eerste lijn met de mogelijkheid om incidenties en prevalenties te meten en deze in de tijd te plaatsen.

2 De mogelijkheid om tot opbouw te komen van "levens-

3 De mogelijkheid een bijdrage te leveren aan de ontwikkeling van 'gezinsgeneeskunde'.

1967: start in een grote huisartspraktijk.

1971: splitsing van de eerste praktijk in tweeèn, twee praktijken toegevoegd, registratie sindsdien constant in deze vier

4 huisartspraktijken: een praktijk in een grote stad, een praktijk in een kleine stad, twee dorpspraktijken; 7 huisartsen.

Samenstelling van de praktijkpopulatie: persoons- en gezins-

Alle reeds bekende chronische morbiditeit; verwijzingen;

Codering van diagnoses met behulp van de gemodificeerde E-lijst (Eimerl-lijst). Gezinsgeorienteerde registratie op een kaartsysteem van alle patiëntgegevens. Alle mutaties van do te registreren items worden doorgegeven op hiervoor be-

Centrale data-opslag en verwerking per computer.

De praktijken beschikken over een computer met een Huisartsinformatie Systeem (Declamed-HIS). Bij het vastleggen en aanleveren van de registratie-data wordt hier nog geen gebruik van gemaakt. Er bestaan wel plannen in deze richting.

\section{Huisartspeilstationsysteem regio Den Haag ${ }^{10} 11$}

\section{Doel}

Peilstationfunctie

Monitoring van locale morbiditeit ten behoeve van de van de Haagse GG en GD (beleidsondersteuning en onderzoek) 
Huidige samenstelling

Bastspopulatie

Inhoud registratie

Methode van registratie

Praktijk-automatisering
1984: begin van activiteiten volgens huidige opzet

53 huisartsen, 43 huisartspraktijken

Circa $112.000(=17 \%$ van de regio)

Per jaar wordt bepaald, welke ziektebeelden of gebeurtenissen worden geregistreerd. In het begin werden alleen infectieziekten geregistreerd, later gemengde items (ongeveer 8 per jaar). Bijvoorbeeld in 1989 onder andere: woonomstandigheden en ongezondheid, heupfracturu, bof en/of bofcomplicatie, te wroeg ontslag ziekenhuis en suicidaal gedrag.

Registratie van de afgesproken items op een registratieformulier, dat énmaal per 4 weken wordt opgestuurd naar de GG \& GD. Centrale data-opslag en verwerking per computher:

Niet gerealiseerd, geen plannen hierwoor.

\section{Continue Morbiditeitsregistratie Peilstations Nederland (Nivel) 13}

Doel:

Gegevens produceren over contacten tussen huisarts en patiênt met betrekking tot een aantal ziekten, klachten of toestanden. Beleidsondersteuning van de overheid is het primaire doel.

Geschiedenis:

1966: IMO Intermitterend Morbiditeits Onderzoek, een gezamenlijk project van het Nederlands Huisartsen Instituut (NHI) en het Nederlands Huisartsen Genootschap (NHG). ${ }^{5}$

1970: CMR Continue Morbiditeits Registratie Peilstations Nederland van het Nederlands Huisartsen Instituut, het Ministerie van Welzijn, Volksgezondheid en Cultuur, en de Geneeskundige Hoofdinspectie van de Volksgezondheid.

1985: NIVEL Voortzetting van het project door het NIVEL (Stichting Nederlands Instituut voor onderzoek van de eerstelijnsgezondheidszorg).

Huidige samenstelling: 45 peilstations (huisartspraktijken), 62 huisartsen

Basispopulatic:

Het is een Landelijk Netwerk. De populatie van de deelnemende praktijken omvat $1 \%$ van de Nederlandse bevolking (Circa 150.000) gespreid over 4 regionale subgroepen en 3 urbanisatiegraden. Er wordt vanuitgegaan dat deze basispopulatie representatief is voor de gehele Nederlandse bevolking.

Inhoud registratic

Jaarlijks worden door de projectcommissie 10 -15 te registreren items vastgesteld. De meeste van deze items (bijvoorbeeld: myocardinfarct, ziektebeelden die op influenza lijken, depressie, moming-after piil) worden enkele jaren vervolgd.

Methode van registratie
Meldingsformulier: wekelijks centrale rapportage op een standaardformulier de z.g. "weekstaat". Centrale data-opslag en verwerking per computer. 


\section{Transitieproject ${ }^{14}$ van het Institumt woor Huisartsgeneeskunde, Universiteit van Amsterdan.}

Doel

Geschiedenis

Huidige samenstelling

Basis populatie

Inhoud registratie

Methode van registratie

Praktijkautomatisering

\section{Amsterdams Peilstation Projekt ${ }^{15-17}$}

Doel

Geschiedenis:

Huidige samenstelling

Basispopulatie

Inhoud van de registratie dam sterdam
Het onderzoeken van de relaties tussen de contactreden van de patiènt, de diagnose door de huisarts en de daarop volgende interventies, samen met de verschuivingen die daarin optreden in de loop wan een volledige episode.

1972: Morbiditeitsanalyse groepspraktijk Ommoord, Rotter-

1979: Het Monitoringproject

1982: Onderzoek van classificatie-stelsels (RFE ICPC) 1984: Transitieproject

21 praktijken, 59 huisartsen

Circa 41.000

Alle ziekten en problemen die tijdens een contact door de patiënt aan de huisarts worden aangeboden, inclusief de interventies die tijdens het consult plaatsvonden. Er wordt informatie verzameld binnen 5 blokken met behulp van de Intemational Classification of Primary Care (ICPC):

a epidemiologische informatie;

b informatie over praktijksamenstelling, verzekeringsvorm en sociaal economische status.

c kwaliteit van de classificatie

d productie: aantal contacten en verwijzingen

e episode georiënteerde informatie

De onderzoekgegevens worden perifeer gecodeend op een registratieformulier: gemiddeld 18 velden per spreekuurformulier. Centrale data-opslag en verwerking per computer. niet toegepast

Peilstation: monitoring van de locale morbiditeit ten behoeve van de GG en GD in Amsterdam. Op basis van deze gegevens kan het gemeentelijk beleid worden ondersteund en verder onderzoek worden verricht.

In 1979 van start gegaan ; initiatief van de Gemeente Am-

38 buisartsen, 31 huisartspraktijken, die geselecteerd zijn op basis van een door de GG en GD representatief geachte praktijksamenstelling.

Circa 73.000

Een programma-commissie bepaalt welke items geregistreerd worden. In 1989 waren dit 6 items: 4 oude items (ook in 1988 geregistreerd): Pelvic inflammatory disease (PID), 
Methode.

Prakitikautomatisering urethritis, bof, gastro-enteritis. 2 nieuwe items: verzoek HIVtest, verwijzing naar de Geestelijke Gezondheidszorg (GGZ) Registratie op formulieren die elke week worden ingestuurd. ('5-daagse rapportage'). Centrale data-opslag en verwerking per computer.

Niet toegepast

\section{Registratienet huisartspraktijken (RNH) van de}

Rijksuniversiteit Limburg (zie hoofdstuk 5)

Doel:

Geschiedenis:

Huidige samenstelling:

Basispopulatie:

Inhoud registratie:

Methode van registratie: Gegevensvastlegging en gegevensaanlevering via de praktijkcomputer van de huisarts.

Centrale data-opslag en verwerking per computer.

Praktijkautomatisering: Praktijkvoering en medische registratie via het microHIS programma. De onderzoekgegevens worden geregistreerd, gecontroleerd en verzendklaar gemaakt door de praktijkcomputer.

\section{Netwerk van researchprojecten Utrecht Huisartsen Instituut van de}

\section{Rijksuniversiteit Utrecht}

Doel:

Geschiedenis:

Huidige samenstelling

Basispopulatie
Het doen van wetenschappelijk onderzoek met hulp van data vastgelegd in de huisartspraktijk via een Huisarts Informatie Systeem. Longitudinaal onderzoek, al of niet episodegericht. Monitoring van huisartsgeneeskundig handelen bijvoorbeeld: preventieve activiteiten, pharmacotherapie, verwijzingen.

1985: gestart als Netwerk Researchprojecten

1989: Nieuwe opzet, waarbij praktijkautomatisering via een voor dit project aangepast HIS een belangrijke rol speelt. De basale organisatiestructuur en de automatisering van de praktijken is voltooid. Het gebruikte HIS wordt nog uitgebreid met een HIOS.

1 solo-praktijk, 2 groepspraktijken, 1 gezondheidscentrum. beoogd aantal patiënten: circa 40.000 . 
Inhoud registratie Morbiditeitsregistratie Methode van registratie

Praktijkautomatisering
Nog niet definitief vastgesteld. gecodeerd met de ICPC.

Het project is nog in de ontwikkelfase. In de toekomst gegevensvastlegging en gegevensaanlevering via de computer van de huisarts en centrale data-opslag en verwerking per computer.

Bij de praktijkvoering en bij het vastleggen van de medische gegevens van de patiënten wordt gebruik gemaakt van het Declamed HIS.

\section{ROHAPRO - Het Rotterdamse Huisartsen Project ${ }^{19}$}

Doel:

Continue geautomatiseerde registratie van morbiditeitsgegevens bij huisartsen ten behoeve van de Hoofdafdeling Epidemiologie van de GGD in Rotterdam.

Geschiedenis: 1987: start van het ROHAPRO-project samen met de afdeling Medische Informatica en de afdeling Huisartsgeneeskunde van de Rotterdamse Universiteit.

1988: De Plaatselijke Huisartsen Vereniging (PHV) en de Ziekenfondsen worden bij dit overleg betrokken.

Huidige samenstelling $\quad 10$ huisartsen: testfase, voorlopig worden niet meer artsen en praktijken hierbij betrokken.

Basispopulatie Beoggd aantal patiënten: $5 \%$ van de bevolking van de regio (Circa 30.000).

Inhoud registratie Nog niet vastgesteld.

Methode van registratie Het project is nog in de ontwikkelfase. In de toekomst gegevenswastlegging en gegevensaanlevering via de computer van de huisarts en centrale data- opslag en verwerking per computer.

Praktijkautomatisering Bij de praktijkvoering en bij het vastleggen van de medische gegevens van de patiënten wordt gebruik gemaakt van het Elias HIS.

\subsection{Beschouwing en conclusie}

Een groot aantal registratieprojecten is actief in Nederland, sommigen zelfs al meer dan 20 jaar. Doelstelling en inhoud van deze registratiesystemen vertonen grote verschillen.

De gevolgde registratiemethoden vertonen meer overeenkomsten: meestal worden de te verzamelen gegevens genoteerd op formulieren, die wekelijks of maandelijks worden opgestuurd naar een centraal verzameladres. Daar worden deze gegevens opgeslagen in een databestand, dat toegankelijk is voor onderzoekers. In tabel 4.1 wordt een overzicht gegeven van het gebruik van de computer bij de besproken registratieprojecten in de opeenvolgende stadia van dataverzameling.

De meeste projecten maken geen gebruik van een praktijkcomputer bij de huisarts en hebben ook geen plannen om dit in de nabije toekomst te gaan doen. Het RNH te Maas- 
Tabel 4.2 Overzicht wan een aanal grole huisartsgeneeskundige Registratieprojecten in Nederlant.

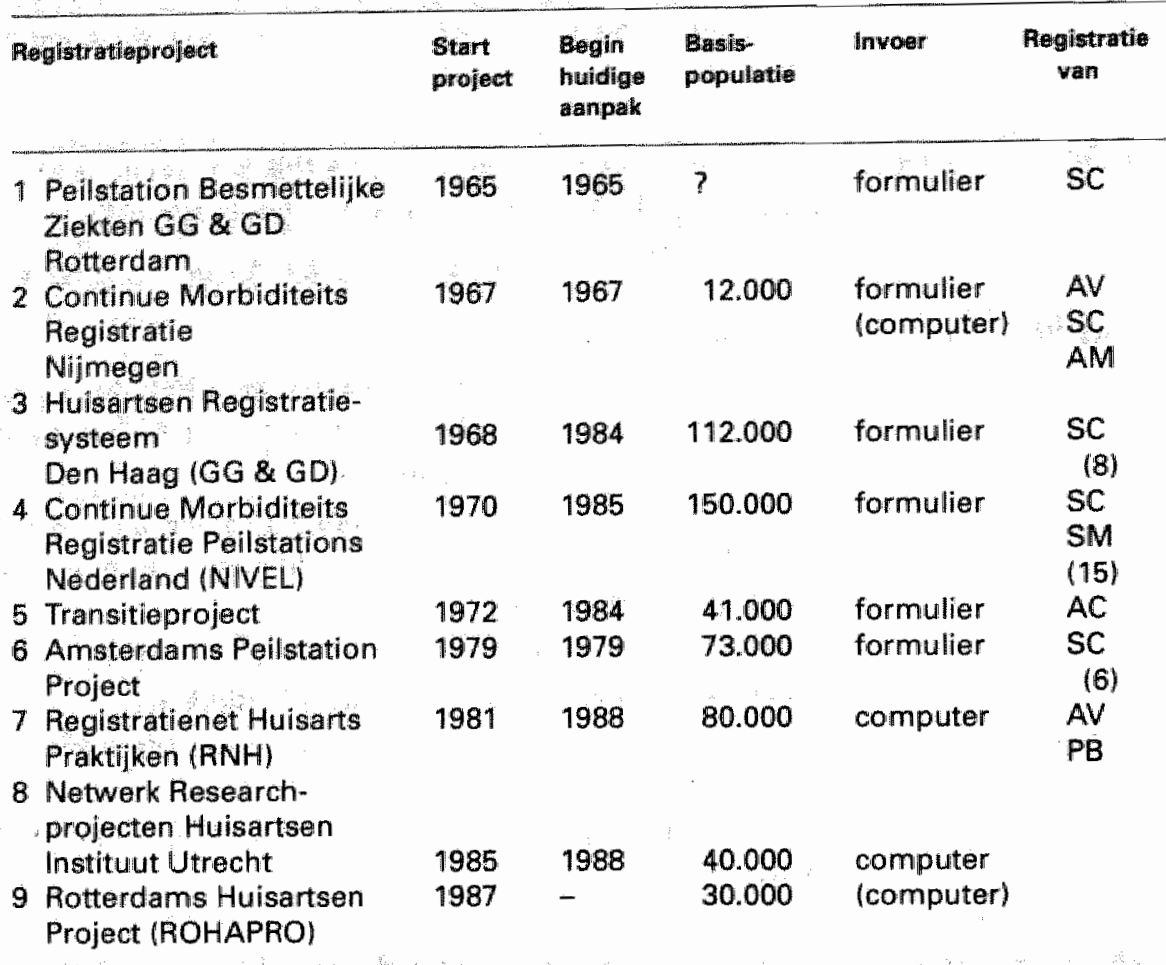

$A C$ alle contacten; AV achtergrondvariabelen, demografische gegevens: $A M$ alle geregistreerde chronische morbiditeit; PB probleemlijsten; SC selectie uit contacten (beperkt aantal items/far); SM selectie uit chronische morbiditeit (beperkt aantal items/jaar)

tricht en het netwerk van researchprojecten in Utrecht, doen dit wel, terwijl ook het ROHAPRO-project te Rotterdam en de CMR te Nijmegen voorbereidingen treffen op dit gebied. Deze projecten zien de gegevenswastlegging aan de bron als een belangrijk hulpmiddel bij de dagelijkse registratie van onderzoekgegevens. In het volgende hoofdstuk wordt hier nader op ingegaan bij de bespreking van het RNH-project.

Het is verleidelijk om still te staan bij de duidelijke verschillen in aanpak van de diverse systemen, zoals getoond in tabel 42 . Wat zijn de specifieke kwaliteiten van de diverse systemen? Voor welke onderzoekvragen bieden zij de beste faciliteiten? Ook is het boeiend on verder door to denken over de methologische aspecten van de vermelde toepassingen van verzameling en bewerking van gegevens. Deze vragen worden echter niet in dit proefschrift beantwoord.

\section{Literatumr}

1 Bouter LM, Dongen MCJM van. Epidemiologisch onderzoek. Opzet en interpretatie. Bohn, Scheltema \& Holkema: Utrecht/Antwerpen 1988. 
2 Grobbee DE, Hofman A. Epidemiologie van ziekten in Nederland. Wetenschappenijke Uitgeverij Bunge, Utrecht 1989.

3 Lamberts H. Morbidity in General Practice. Huisartsenpers, Utrecht, 1984.

4 Bosch W van den, Weel C van. Leeftijd-en geslachtsverschillen bij fracturen en andere traumata. Huisarts Wet 1989; 32: 246-48

5 Veen WA van. Morbiditeits onderzoek Huisarts Wet 1982; 25: 110-12

6 Hoekstra M, Bosch W van den. Naar een informatienetwerk in de Eerste Lijn, rapportage. Utrecht, 1981 ; Nederlands Huisartsen Instituut.

7 Huisman J. Vijftien jaar peilstationonderzoek vijftien jaargangen Epidemiologisch Bulletin. Huisarts Wet 1980; $23: 360-1$.

8 Anoniem. Morbidity figures from general practice 1978-1982. Nijmegen, 1985; Nijmeegs Huisartsen Instituut.

9 Weel C. van, Bosch WJHM van den, Hoogen HJM van den. De continue morbiditeitsregistratie Nijmegen. Huisarts Wet 1986; 29:373-77

10 Nijhuis HGJ, Notowicz A. Ulcus pepticum en Pityriasis rosea; epidemiologische mededelingen. Huisarts Wet $1986 ; 29: 324-25$.

11 Relyveld J, Bergink AH, Nijhuis HGJ. Ulcus cruris, wratten en sterfsituatie. Huisarts Wet 1988; 31: 266.

12 Bartelds AIM Continue Morbiditeitsregistratie Peilstations Nederland 1985. Huisarts Wet 1987; 30: 222-26.

13 Fracheboud J, Berkel J, Bonjer FJ, Colette HJA. Thuisbehandeling na een accuut hartinfarct: hoe vaak en welke patienten? Huisarts Wet 1989; 32: 162-164.

14 Lamberts $H$, Brouwer $\mathrm{H}$, Groen ASM, Huisman H. Het transitiemodel in de huisartspraktijk. Huisarts Wet 1987; 30: 105-13

15 Belleman SJM. De contactfrequentie van allochtone patiënten. Huisarts Wet 1986; 29: $48-50$

16 Boeke J. De morning-after pill. Huisarts Wet 1988; 31: 412-13.

17 Leentvaar-Kuijpers A. Jaarverslag 1988 Amsterdams Peilstation Project

18 Geus CA de, Höfen R von, Metsemakers JFM Huisarts en computer. Op weg naar een geautomatiseerd registratiesysteem voor wetenschappelijk onderzoek in de huisartspraktijk. MC 1984; 19: 1289-90

19 Jaarverslag 1988 GGD/EPI Rotterdam. Rotterdam; 1989

\section{Bijlage 4.1. Morbiditeits Registratie Netwerk Groningen (RNG)}

$\mathrm{Na}$ het afsluiten van de tekst van dit hoofdstuk werden ook vanuit de Rijksuniversiteit Groningen plannen gepubliceerd voor het opzetten van een registratienetwerk. Deze bijlage gaat hier nader op in.

Doel

Het krijgen van een geautomatiseerd gegevensbestand, gebaseerd op contactregistratie, ten behoeve van onderzoek, onderwijs, beleid en patièntenzorg in de huisartspraktijk.

\section{Geschiedenis}

1987: Start van het RNG met de automatisering van de Universitaire Groepspraktijk Antonius Deusinglaan.

\section{Huidige samenstelling}

Vier 0.5 fte huisartsen, 1 groepspraktijk 


\section{Huidige basispopulatie}

4700 patienten

Beoogde basispopulatie.

20.000 tot 30.000 patienten

\section{Inhowdregistratie}

Patientachtergrondvariabelen (leeftijd, geslacht, sociaaleconomische status) en van elk contact de diagnose, de voorgeschreven medicatie en eventuele verwijzingen naar specialisten of andere hulpverleners in de le en $2 \mathrm{e}$ lijn.

In de Uniwersitaire Groepspraktijk wordt van alle patiènten ook een probleemlijst bijgehouden.

\section{Methode van registratie}

Bij elk contact wordt geautomatiseerd de diagnose, de voorgeschreven medicatie en eventuele verwijzingen vastgelegd. Voorlopig wordt daarnaast de groene NHG-kaart behouden. Er is sprake van een decentrale data-entry.

\section{Praktijkautomatisering}

Patièntadministratie en een beperkte medische registratie via het Microhis-programma. Het gegevensbestand wordt decentraal per praktijk gecorrigeerd en vervolgens en centraal gecompileerd en geanalyseerd. 


\section{Het geautomatiseerde steekproefbestand voor huisartsgeneeskundig onderzoek van de Rijksuniversiteit Limburg}

Het Registratienet Huisartspraktjken (RNH) van de Rijksuniversiteit Limburg bouwt een centrail steekproefbestand op van geanonimiseerde patient-achtergrondvariabelen en probleemlijsten betreffende circa 80.000 patiënten. In dit artikel worden de doelstelling wan het $\mathrm{RNH}_{\mathrm{s}}$ de methode van registratie en de wijze van dataverzameling besproken, en wordt ingegaan op de toepassingsmogelijkheden. Het opgebouwde centrale steekproefbestand moet vooral gezien worden alls een index. die verwijst naar de individuele patientregistratie bij de huisarts. Deze functie kan men wergelijken met de functie van een literatuur-database als Medline.

\subsection{Inleiding}

Binnen de medische faculteit van de Rijksuniversiteit Limburg is in de loop van de jaren tachtig behoefte ontstaan aan een flexibel onderzoeksysteem waarvan interne en externe onderzoekers gebruik zouden kunnen maken. $\mathrm{Na}$ een intensieve voorbereidingsperiode is in 1985 officieel gestart met een gemeenschappelijke infrastructuur voor vier registerprojecten. De databestanden met patièntgegevens van deze projecten worden beheerd door het Medisch Maatschappelijk Informatie- en Documentatiecentrum (MEMIC) van de universiteit. Hieruit kunnen op verzoek van wetenschappelijke onderzoekers gegevens worden geleverd. Onderzoeksprojecten moeten voldoen aan duidelijk omschreven voorwaarden; controle vindt plaats door een Raad van Toezicht.

Een van de vier registerprojecten is het Registratienet Huisartspraktijken (RNH). De eerst fase van dit project is inmiddels afgerond: de ontwikkeling van een volledig geautomatiseerd registratienet. Met dit systeem wordt een centraal geanonimiseerd huisartsgeneeskundig steekproefbestand van patiẻnt-achtergrondvariabelen en probleemlijsten op gebouwd.

\subsection{Registratienet Huisartspraktijken}

De belangrijkste doelstelling van het RNH is: het opzetten van een geautomatisserd huisartsgeneeskundig steekproefbestand met cen beperkte set geanonimiseerde achtergrondgegevens en een volledige probleemlijst van elke geregistreerde patiént.

Het 'huisartsregister' bij het MEMIC moet fungeren als een flexibele index, die verwijst

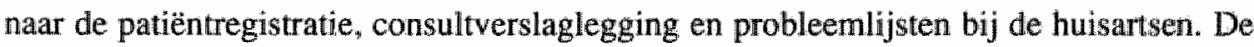
opzet is te vergelijken met die wan een literataur-database zoals Medline, die een effi-

Dit hoofdstuk werd eerder gepubliceerd als: Höppener P, Knottnerus JA, Metsemakers IFM, Kocken RJJ, Limonard ChBG. Het Registratienet Huisartspraktijken van de Rijksuniversiteit Limburg. Huisarts Wet 1990; 33(2): 66-9. De tabellen en aantallen zijn aangepast aan de situatie per 1 jumi 1990. 
ciente verkenning van c.q verwijzing haar de oorspronkelijke literatuir mogelijk maakt. Een onderzoeker kan bijvoorbeld via een gerichte vraag alle beschikbare literatuur van de laatste then jaar over diabetische neuropathie opvragen. Hij krijgt dan een overzicht van alle in de databank aanwezige informatie en een verwijzing naar de oorspronkelijke publikaties. Is deze informatie onvoldoende, dan kan hij via een universiteitsbibliotheek de oorspronkelijke publikaties opvragen. Een soortgelijke wraag kan de onderzoeker aan het MEMIC stellen over patienten met een diabetische polyneuropathie: hij krijgt dan alle in het RNH-bestand aanwezige gegevens van deze patiëntengroep. Het MEMIC kan vervolgens de onderzoeker die meer gedetailleerde gegevens nodig heeft, de weg wijzen natar de patientendossiers bij de registrerende huisartsen. Aanvullende informatie is snel terug te vinden in de praktijkcomputers, in de oude "groene kaart" en in het brieven-archief.

\subsection{Registratie}

Het invoeren van een computer in de huisartspraktijk vraagt veel inzet, energie, tijd en volharding. 'Het lag dan ook voor de hand om enkele reeds volledig geautomatiseerde huisartspraktijken bij het RNH-project te betrekken. Vanaf mei 1988 worden in vier van deze praktijken data verzameld voor het 'huisartsregister' bij het MEMIC. Tegelijkertijd werd een begin gemaakt met de automatisering in elf andere praktijken. Ook deze praktijken beschikken nu over een up-to-date leeftijd/geslachtsregister en leveren data aan het centrale huisartsregister.

De vijftien praktijken maken gebruik van het programma MicroHIS. De criteria voor de te verzamelen data zijn vastgelegd in een 'Registratie Naslag Hulp' en er wordt gecodeerd volgens de International Classification of Primary Care (ICPC) en de criteria van de ICHPPC-2-defined. ${ }^{2-4}$

In de deelnemende praktijken wordt dagelijks de registratie var een aantal patiënten bijgewerkt. De huisarts selecteert hiervoor een aantal kaarten en werkt verwolgens de gegevens bij, liefst van het hele gezin of woonverband. Gemiddeld gaat het om vijf patiënten per full-time werkende arts per dag. De datum warop dit gebeurt, is de "update-datum'. De registrerende huisarts mag deze datum alleen invullen ${ }^{*}$ wanneer hij de achtergrondgegevens van de patiènt heeft vastgelegd en gecontroleerd en tevens een volledige lijst heeft aangelegd van relevante problemen. Het gaat daarbij om de volgende gegevens:

\section{Patien-achtergrondwariabelen}

- code registrerende arts (volgens afspraak RNH);

- patient-identificatienummer (unieke interne code);

- geslacht;

- geboortedatum en geboortegemeente;

- burgerlijke staat en soort woonverband;

- woongemeente en 4 cijfers van de postcode;

- intrededatum (eerste contact met huisarts);

- update-datum (datum waarop registratie werd bijgewerkt); 
- verzekeningsvorm;

- reden vertrek en vertrekdatum (incl datum overlijden);

- opleidingsnivean in drie schalen (lager, middelbaar en hoger).

\section{Probleemilyst}

Als probleem wordt beschouwd datgene waarvoor nader onderzoek of handelen door werkers in de gezondheidszorg nodig is, of iets dat het lichamelijk of geestelijk welzijn kan verminderen of heeft verminderd (Sandlow $)$. Op de probleemlijkst komen te staan: chronische problemen (langer dan 6 maanden bestaand), permanente problemen (geen volledig herstel verwacht) en problemen van blijvend belang voor de gezondheidsvoestand van de patiènt.

De volgende soorten problemen worden onderscheiden:

- diagnosen (bv. diabetes mellitus, bronchuscarcinoom);

- klachtenpatronen (bv, chronische rugklachten);

- afwijkende uitslagen en bevindingen (bv. papsmear klasse IIIa);

- risicofactoren (bv. drugsgebruik, belaste familieanamnese);

- overige problemen (bw. allergie voor amoxicilline).

Per probleem wordt geregistreerd:

- de status: $\mathrm{A}=$ actief; $\mathrm{B}=$ blind (inactief, speelt thans medisch geen rol);

- de datum: zowel datum A(ctief) als datum B(lind);

- de ICPC-code.

Tijdens het spreekuur worden de gegevens van de al geregistreerde patiënten op volledigheid en juistheid gecontroleerd en geactualiseerd. Daamaast worden geboorte, vertrek en overlijden standaard bijgehouden. In een later stadium zal door middel van een posten quête aanvullende informatie worden gevraagd aan patiënten die in de tussentijd nog op het spreekuur zijn verschenen. Deze enquête zal periodiek herhaald worden.

\subsection{Kwaliteitsbewaking}

Eenmaal per drie maanden worden de geregistreerde gegevens geanonimiseerd op een diskette aangeleverd aan het MEMIC.

Kwalititsbewaking vindt als volgt platats:

- Geautomatiseerde foutcontrole via interne programmatuur van MicroHIS bij de huis* arts. Dit houdt in: controle op foute inbreng en op ontbrekende gegevens en een globale controle op de representativiteit van de aangeleverde data. Per praktijk wordt nagegaan of de leeftijd- en geslachtsverdeling van de ingevoerde patiëntengroep overeenkomen met wat werwacht mocht worden gezien de praktijksamenstelling.

- Intercollegiale inhoudelijke toetsing. In de eerste plaats worden consensus-bijeenkomsten gehouden over de diverse aspecten van het registreren van basisgegevens en probleemlijsten. In de tweede plaats is er steekproefgewijze wederzijdse controle van de ingevoerde data, met speciale aandacht voor een correcte codering. De toetsing ge schiedt in vijf vaste groepen.

- Feedback door het MEMIC over inconsistenties, fouten en omissies in de aangeleverde gegevens. 
Waar anleiding van de foutcontrole en de intercollegiale toetsing worden de richtlijnen en definities verder uitgewerkt door een "probleemlijst-commissie".

\subsection{Verzamelde data}

In total worden nu gegevens aangeleverd door 43 artsen, werkzaam in vijftien huisartspraktijken. Per 1 maart 1989 omvatte het register achtergrondgegevens en probleemlijsten van 5342 patienten. Per 1 juni 1990 waren de gegevens van 28.672 patiënten in de centrale computer bij het MEMIC opgeslagen.

Na de startfase bleek een groei van het bestand met 5000 patiënten per drie maanden goed halbaar. Wanneer alles volgens plan verloopt, kan binnen drie jaar een steekproefbestand yan 80.000 ingeschreven patienten worden opgebouwd (en onderhouden). Dit bestand staat onder duidelijk omschreven voorwaarden open voor wetenschappelijk onderzoek en/of maatschappelijke informatie.

Tabel 5.1 geeft een overzicht van de verdeling van de patiënt-achtergrondvariabelen;

Tabel 5.1 Patientachergrandwariabelen RNH-bestand per 1-6-1990.

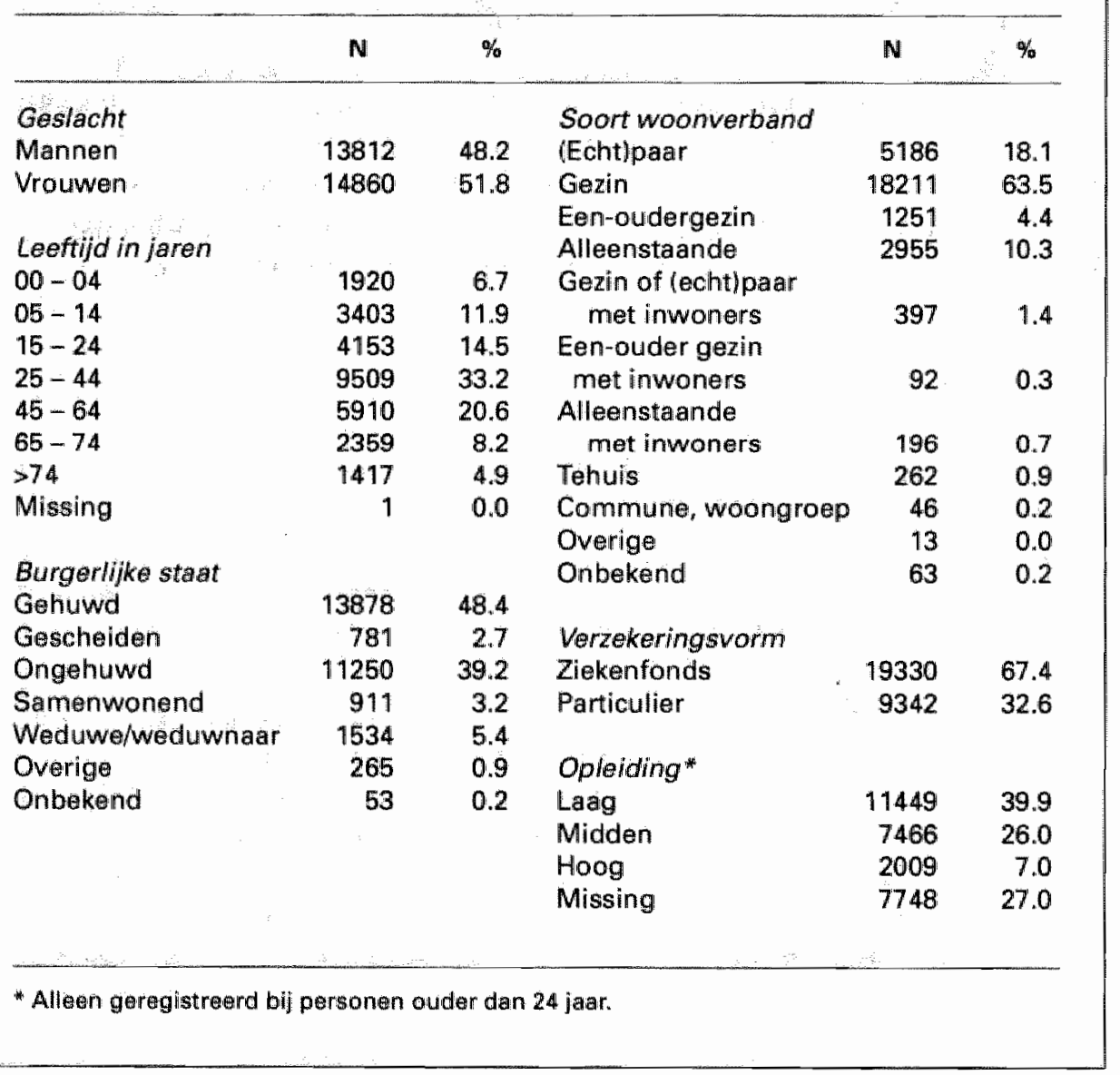


Tabel 5.2 Top 20 actieve problemen in huidige bestand met probleentijsten van 28.672 patientern.

\begin{tabular}{|c|c|c|c|c|c|}
\hline ICPC-Omschrijving & Code & $\mathbf{N r}$ & Toteial & Man & Vrouv \\
\hline Geneesmiddel bijwerking juiste dosering & A85 & 1 & 2432 & 738 & 1694 \\
\hline Hypertensie prim/sec zond.org.beschadig. & K86 & 2 & 1525 & 537 & 988 \\
\hline Asthma & R96 & 3 & 1066 & 563 & 503 \\
\hline Hoolkoorts & $\mathrm{R} 97$ & 4 & 990 & 512 & 478 \\
\hline Diabetes mellitus & T90 & 5 & 760 & 300 & 460 \\
\hline Gevoel van angst nerveusheid & P01 & 6 & 711 & 244 & 467 \\
\hline Adipositas (bmi 30) & T82 & 7 & 706 & 257 & 449 \\
\hline Lage rugklachten zonder uitstraling & L03 & 8 & 667 & 380 & 287 \\
\hline Constitutioneel eczeem & S87 & 9 & 642 & 291 & 351 \\
\hline Arthrosis deformans v.d.wervelkolom & L84 & 10 & 577 & 253 & 324 \\
\hline Allergie nao allergische reactie & A12 & 11 & 571 & 270 & 301 \\
\hline Discusdegeneratie met uitstraling & L86 & 12 & 563 & 313 & 250 \\
\hline Varices van de benen & K95 & 13 & 520 & 93 & 427 \\
\hline Doofheid of hardhorendheid neg & H86 & 14 & 505 & 268 & 237 \\
\hline Gonarthrose & L90 & 15 & 503 & 165 & 338 \\
\hline Verworven milsvormingen & $\llcorner 98$ & 16 & 489 & 206 & 283 \\
\hline Chronische bronchitis, bronchiectasien & R91 & 17 & 478 & 277 & 201 \\
\hline Overgewicht (BMI) & T83 & 18 & 473 & 200 & 273 \\
\hline Contact eczeem, andere vormen eczeem & $\mathrm{s} 88$ & 19 & 424 & 141 & 283 \\
\hline Syndromen samenth.met cervicale wk/andere & L83 & 20 & 405 & 166 & 239 \\
\hline
\end{tabular}

Voorbeeld van de berekening van de prevalentie L86, actief:

Totaal

Mannen

Vrouwen
$563 / 28672=2.0 \%$

$313 / 13812=2.3 \%$

$250 / 14860=1.7 \%$

de tabellen 5.2 en 5.3 geven een owerzicht van de top-20 actieve en inactieve problemen in het huidige bestand (peildatum 1 juni 1990). Deze lijsten verschillen van de bevindingen in andere registraties. Dat was ook te verwachten, gezien de gehanteerde definitie van een probleem. Eenmalige verkoudheidsklachten vindt men bijvoorbeeld niet op deze lijst, omdat deze niet als "probleem" worden geregistreerd.

\subsection{Toepassingen}

Voor de hand liggende toepassingsmogelijkheden zijn: huisartsgeneeskundig onderzoek (peilstation-functie, monitoring, transversal onderzoek, patiënt-controle onderzoek, longitudinaal onderzoek/cohortonderzoek, interventie-onderzoek), toetsing, onderwijs en beleidsondersteuning. ${ }^{6-8}$

Afhankelijk van de wraagstelling kunnen verschillende tellers en noemers gekozen worden. De teller kan bestaan uit het aantal op een bepaald moment of in een bepalide periode geregistreerde problemen, maar ook uit bepaalde (combinaties van) persoonsachtergrondvariabelen. De noemer zal vaak de gehele geregistreerde populatic beslaan, 
Tabel S.3 Top 20 inactieve problemen in huidige bestand met probleemlijsten van 28.672 patiënicen.

Hypertrofie, chron infect tonsill./aden.

$\begin{array}{rrrrr}\text { R90 } & 1 & 2074 & 1007 & 1067 \\ \text { D88 } & 2 & 919 & 378 & 541 \\ \text { D89 } & 3 & 698 & 563 & 135 \\ \text { L76 } & 4 & 681 & 383 & 298 \\ \text { W92 } & 5 & 656 & 0 & 656 \\ \text { W13 } & 6 & 645 & 0 & 645 \\ \text { D98 } & 7 & 623 & 127 & 496 \\ \text { Y13 } & 8 & 621 & 621 & 0 \\ \text { L99 } & 9 & 557 & 285 & 272 \\ \text { L86 } & 10 & 529 & 317 & 212 \\ \text { L72 } & 11 & 509 & 212 & 297 \\ \text { X78 } & 12 & 468 & 0 & 468 \\ \text { U95 } & 13 & 453 & 299 & 154 \\ \text { L96 } & 14 & 420 & 316 & 104 \\ \text { X99 } & 15 & 404 & 0 & 404 \\ \text { L73 } & 16 & 394 & 238 & 156 \\ \text { D99 } & 17 & 379 & 177 & 202 \\ \text { W82 } & 18 & 378 & 0 & 378 \\ \text { K95 } & 19 & 317 & 84 & 233 \\ \text { H71 } & 20 & 311 & 164 & 147\end{array}$

Appendicitis

Hernia inguinalis

Andere fracturen

Gecompliceerde partus llevendgeborene

Anticonceptie sterilisatie vrouw

Cholecystitis cholelithiasis

Sterilisatie man

Andere aandoeningen bewegingsapparaat

Discus degeneratie met uitstraling

Fractuur radius/uina

Benigne neoplasmata uterus/cervix uteri

Urolithiasils

Acute traumata meniscus en kniebanden

Andere ziekten gesl.org/borsten vrouw

Fractuur tibia/fibula

Andere ziekten tr.digestivus

Spontane arbortus

Varices van de benen

Acute otitis media myringitis

Voorbeeld van de berekening van de prevalentie $\mathrm{L} 86$, inactief:
Totaal
$529 / 28672=1.9 \%$
Mannen
$317 / 13812=2.3 \%$
Vrouwen
$212 / 14860=1.4 \%$

Uit de tabellen 5.2 an 5.3 :

De prevalentie van L86, actief + inactief :

Totaal

Mannen

$1092 / 28672=3.8 \%$

$630 / 13812=4.6 \%$

Vrouwen

$462 / 14860=3.1 \%$

maar men kan zich ook richten op een subgroep, te definiëren aan de hand van bepaalde problemen of bepaalde persoons-achtergrondvariabelen. Hoewel het verstrekken van descriptieve gegevens over incidentie en prevalentie niet het centrale doel van het systeem is, kunnen deze grootheden worden afgeleid, met inachtneming van de definitie van Sandlow.

De (punt)prevalentie van een probleem is de frequentie van dit probleem in de geregistreerde populatie op de peildatum. Daarbij kan deze apart worden berekend voor actieve en inactieve problemen. De incidentie van een probleem is te berekenen als het aantal keren dat dit probleem nieuw is verschenen op probleemlijsten per 1000 personen per jaar. Het is belangrijk zich te realiseren, dat het bij het verschil tussen incidentie en prevalentie om iets anders gaat dan bij het verschil tussen actieve en inactieve problemen. Het laatste onderscheid is een consequentie van het langdurig bijhouden van probleemlijsten. 
Een probleem begint 'actief' (bijwoorbeeld een ziek orgaan), kan later inactief' worden (bijvoorbeeld: hersteld, status na operatie), en kan vervolgens weer actief worden (bijwoorbeeld recidief na operatie). Incidente problemen zijn op het moment van optreden actief; prevalente problemen kunnen als actief en als inactief geregistreerd staan. In de tabellen 5.2 en 5.3 hebben we, bij wijze van voorbeeld, prevalenties berekend van het probleem L86 (discusdegeneratie met uitstraling) ower het totale bestand. Het blijkt dat dit probleem iets vaker als actief te boek staat en bij mannen wat meer voorkomt dan bij vrouwen.

Incidenties zljn in principe reeds te berekenen en/of te extrapoleren op grond van de huidige (korte) registratieperiode, maar het is beter hiermee te wachten tot we langer dan twee jaar hebben geregistreerd.

Het is niet altijd mogelijk alle voor een onderzoek vereiste gegevens uit het centralle bestand te halen; soms zullen bij een specifieke vraagstelling additionele gegevens verkregen moeten worden op basis van een gerichte steekproef uit het bestand van de huisarts. Daarnaast zal aanwullende informatie af en toe bij de patiënt zelf gezocht moeten worden, bijwoorbeeld door een enquête of door lichamelijk onderzoek. Dank zij de eenvoudige centrale identificatie kunnen mensen met een probleem (cases) en mensen zonder dat probleem (controles) via de huisarts gericht worden opgespoord en benaderd.

Bij het berekenen van prevalenties en incidenties, en bij het generaliseren van bevindingen in het centrale steekproefbestand wordt uitgegaan van de premisse dat het reeds ingevoerde bestand representatief is voor de totaal in te voeren populatie. Uiteraard zal dit laatste meer gegarandeerd zijn naarmate het bestand groeit. De representativiteit van de aangeleverde data wordt verder bevorderd door de reeds beschreven kwaliteitsbewaking aan de bron en de directe feedback hierop.

Vooralsnog geldt als beperking, dat patiëntenkaarten worden bijgewerkt naar aanleiding van het spreekuurbezoek van eén van de leden van een woonverband/gezin. Pas wanneer het bestand de gehele bij de huisartsen ingeschreven populatie dekt, is selectiebias geheel uitgesloten.

\section{Literatuur}

1 Westerhof $\mathrm{H}$, red. Automatiseren in de huisartspraktijk. Utrecht: Nederlands Huisartsen Genootschap, 1989.

2 Lamberts H, Wood M. ICPC: International Classification of Primary Care. Oxford: Oxford University Press, 1987.

3 Anonymous. ICHPPC-2 defined. Inclusion criteria for the use of the rubrics of the International Classification of Health Problems in Primary Care. Oxford: Oxford University Press, 1983.

4 Huynen LG, Muyrers PE, Knottnerus JA. Registreren van diagnosen met behulp van diagnostische criteria. Huisarts Wet 1987; 30: 237-9.

5 Metsemaker JF, Plagge HW, De Kanter J. De Probleemlijst. Huisarts Wet 1988; 30; 379-81.

6 Anonymous. Computer-stored medical records. Their future in Medical Practice. JAMA $1988 ; 259: 3433-9$.

7 Hoelen AJ. Kwaliteit en doelmatigheid van medische databases; kwalliteitszorg in de landelijke gezondheidszorg. TMI 1986; 15:14-6.

8 Schadé E, Brouwer H, IJzermans CJ. De kinderjaren woorbij. Huisarts Wet 1988; 31 : 176-8. 


\section{Verslag van een automatiseringsproject}

In dit hoofdstuk wordt nader ingegaan op de automatisering van het Registratienet Huisartspraktijken. De opbouw wan een centraal huisartsgeneeskundig steekproefbestand werd mogelijk gemaakt door de automatisering van een aantal huisartspraktijken. Aspecten van dit automatiseringsproject, dat aan de wieg stond wan het RNH, worden beschreven: de implementatie van de automatisering in de huisartspraktikken, de datacontrole bij de huisarts, de data-overdracht naar het centrale bestand en de centrale opslag en bewerking wan de op deze wijze verzamelde gegevens. Tevens wordt duidelijk gemaakt hoe de verzamelde gegevens op verschillende niveaus woor onderzoek gebruikt kunnen worden. Gezien de korte looptijd wan het project werd nog geen onderzoek verricht naar de acceptatie van de automatisering door huiusartsen en praktijkmedewerkers.

\subsection{Overwegingen bij de keuze voor automatisering}

Omdat de aanwezigheid van complete en betrouwbare patiëntgegevens bij de huisarts een basiswoorwaarde is voor de opbouw van een centraal geautomatiseerd steekproefbestand, werd automatisering van de registrerende praktijken gezien als een essentiële voorwaarde voor het slagen van dit registratieprojekt. ${ }^{1}$ Met name leek de praktijkcomputer met een Huisarts Informatie Systeem (HIS) op de volgende punten beter te scoren dan de "groene kaart": $:^{2-6}$

- de computer nodigt uit tot ordelijke gegevensopslag;

- de in een computer opgeslagen gegevens (ook tekst) zijn beter toegankelijk voor de onderzoeker en leesbaar;

- de 'patiëntenkaarten' kunnen snel opgezocht worden via verschillende indexsleutels;

- er zijn vrijwel geen zoekgeraakte of 'verdwaalde' patiëntenkaarten;

- geautomatiseerde bestanden zijn goed toegankelijk en kunnen de gevraagde informatie snel leveren (afhankelijk van gebruikte systeem);

- geautomatiseerde datacontrole kan al plaatsvinden aan de basis, dus in de praktijkcomputer;

- het genereren vän overzichten voor inhoudelijke toetsing is eenvoudig;

- er zijn veel ruimere mogelijkheden voor ondersteuning en controle bij het coderen;

- de extra praktijkondersteuning die de computer biedt compenseert reeds na enkele jaren de extra praktijkbelasting van het registreren;

- voorafgaande ervaring met geautomatiseerde probleemgeoriënteerde registratie heeft geleerd, dat het bijhouden van een probleemlijst geleidelijk een vanzelfsprekende 'routine' wordt, die hoort bij de normale consultwoering; 
- het gebruik van een geautomatiseerde trefwoondenlijst kan het coderen van probleem-

lijsten ondersteunen en vermindert interarts-en intra-arts variatie, toetsing is hierbij bovendien beter mogelijk.

Deze voordelen wegen duidelijk op tegen een aantal contra-argumenten:

- de financiele consequenties;

- de afhankelijkheid wan een nieuwe techniek met alle onzekerheden die daaraan verbonden zijn. Een niet goed functionerende praktijkcomputer kan een voortdurenda bron van ergernis zijn voor assistente, arts en patiènt;

- de problemen die vrijwel altijd optreden bij het opstarten van een automatiseringsproject: met name het vaak moeizame leerproces bij de deelnemers en de te verwachten "kinderziektes" van de geinstalleerde apparatuur;

- de weerstand tegen automatisering die bij een niet te verwaarlozen arantal medewerkers van de RNH-praktijken aanwezig was;

- de grote claim die het invoeren van automatisering zou leggen op de ter zake deskundige stafmedewerkers van het $\mathrm{RNH}$;

- de privacy-aspecten die een rol spelen bij het gebruik van geautomatiseerde bestanden met patiëntgebonden gegevens.

De argumenten, die een rol speelden bij de keuze voor automatisering, speelden óók een rol bij de keuze voor een commercieel software-pakket. Er werd gezocht naar een Huisarts Informatie Systeem met een medische module die goede faciliteiten zou bieden voor een gebruikersvriendelijke journaalregistratie in 'vrije tekst' probleemlijst-registratie en codering met de ICPC.

De aanwezigheid van een liefst reeds in het veld geteste faciliteit voor 'query and report" was een absolute conditie. Daarnaast werd meegewogen of er voldoende garanties waren voor een solide ondersteuning en service. Uiteindelijk werd bij een testronde in november 1987 gekozen voor het microHIS pakket van VVAA-praktijkautomatisering, waarbij het ELIAS-HIS volgde alls goede tweede. ${ }^{89}$

Met name de volgende factoren speelden een beslissende rol bij deze keuze voor het microHIS:

- de zeer flexibele en 'open' gegevensstructuur, waarin alle vastgelegde gegevens via een 'pseudoprogrammeertaal' direct bereikbaar zijn;

- de aanwezigheid van een aantal huisartsen in de regio die reeds veel ervaring met dit systeem hadden en er tevreden over waren;

- de ondersteuning van de gebruikers door een reeds enkele jaren bestaande landelijke gebruikersvereniging (Orghis);

- de toezegging van de producent om met de afdeling Medische Informatica en Statistiek van de Rijksuniversiteit Limburg te participeren in de ontwikkeling van een 'researchmodulle".

\subsection{Implementatie van de automatisering}

\subsubsection{Implementatie van de automatisering}

Definitieve afspraken over een gefaseerde introductie en implementatie van automatisering en registratie $\mathrm{kwamen}$ pas aan bod, toen de contract-onderhandelingen met de le- 
werancier waren afgerond. In mei 1988 begon in een 4 -tal praktijken, die al gerwime tijd ervaring hadden met dit HIS-programma, de registratie volgens het RNH-concept. Op deze wijze kon via deze "pilot-praktijken" al de nodige routine opgedaan worden en werden alle gemaakte kodeer-en registratie-afspraken aan een veldtest onderworpen. Tegelijkertijd kon de 'query-procedures' voor de dataverzameling worden ontwikkeld en verder worden uitgetest in de praktijk.

In augustus 1988 werden de 7 geacademiseerde praktijken, die al langer samenwerkten met het RNH woorzien van hardware en software. Rond de jaarwisseling was de toch altijd zeer moeizame implementatiefalse en leerfase achter de rug. ${ }^{10}$ Bij één van de elf praktijken verliep een en ander minder voorspoedig: de aanlevering van data aan het centraal bestand kwam pas medio 1989 goed op gang.

In 1989 zijn er nog 4 praktijken bij gekomen: in totaal zijn nu 15 praktijken met een basispopulatie van circa 80.000 patiênten en 43 huisartsen geautomatiseerd.

\subsubsection{De gebruikte hardware en software}

Afhankelijk van de praktijkgrootte werden alle niet geautomatiseerde RNH-praktijken voorzien van de volgende hardware-configuratie:

- een $80286 / 12 \mathrm{Mhz}$ of $80386 / 16 \mathrm{Mhz}$ computer met 1 of $2 \mathrm{Mb}$ intern geheugen en 40 Mb of $70 \mathrm{Mb}$ extern geheugen (Harddisk);

- Tapestreamer $60 \mathrm{Mb}$;

- 1 tot 5 Wyse-50 terminals + printers.

Onder het gebruikte operating system Concurrent Dos XM 6.0 of Concurrent Dos 386 van Digital Research werden 2 tot 6 multi-user werkplekken gerealiseerd, én voor elke arts en éen of twee voor de assistente(s). Eén grote groepspraktijk beschikt over 3 sets met ieder 4 werkplekken en ging over nalar een netwerkconfiguratie in april 1990.

Het microHIS-programma beschikt over een basis-module, een medische module en een apotheekmodule en voldoet aan de "WCIA-normen" ${ }^{11}$ " 2 De registrerende praktijken gebruiken deze software primair ter ondersteuning van de praktijkvoering. De ondersteuning van het "registratiedoel' is een secundair maar daarom niet minder essentieel effect.

Dank zij de open en flexibele structuur van het HIS-programma kunnen databestanden en delen van de programmatuur, die primair worden gebruikt voor de ondersteuning van de praktijkvoering, gemakkelijk 'op maat gemaakt worden' voor registratie-doeleinden (tabel 6.1). Met name betreft het hier de volgende onderdelen:

- Tabellen "die onder andere een vrije keuze van het toe te passen codesysteem mogelijk maken.

- Hulpschermen die toelichting geven bij het actuele scherm en veld.

Bijvoorbeeld: instructie bij coderen van patiènt-achtergrond-variabelen (zie fig. 1). Daarnaast openen zij de deur naar een grote verzameling medische protocollen en 'standaarden', die zijn ingebracht door collega's die lid zijn van de gebruikersvereniging (zie fig. 2).

- Contra-indicatiebewaking

De bij cen patient geregistreerde probleemcode(s) en de "groepskenmerken" van voorgeschreven medicamenten vormen de basis voor deze bewakingsfaciliteit. Het goed registreren ến coderen van problemen wordt direct 'beloond' met een contra-indicatiebewaking bij het voorschrijven van medicijnen. 
Tabell 6.1 Gebruk van de HIS-bestanden woor registratiedoeleinden binnen het Registratienet Huisartspraktijken.

\begin{tabular}{|c|c|c|c|c|}
\hline $\begin{array}{l}\text { Databuestanden en/of } \\
\text { programma-onderdelen }\end{array}$ & $\begin{array}{l}\text { Ondiersteuning } \\
\text { praktijkvoering }\end{array}$ & $\begin{array}{l}\text { Dataltekst/ } \\
\text { voor } \\
\text { research }\end{array}$ & $\begin{array}{c}\text { Dataset } \\
\text { voor steek: } \\
\text { proefbestand }\end{array}$ & $\begin{array}{c}\text { Ondersteuning } \\
\text { registratile } \\
\text { codering }\end{array}$ \\
\hline Basisgegevens patiënter & en & + & + & \\
\hline Financiële gegevens & + & & & \\
\hline Tabellen & + & & & \\
\hline $\begin{array}{c}\text { Journaal (werslag } \\
\text { consultatie) }\end{array}$ & + & + & & \\
\hline Probleemlijst & + & $\begin{array}{l}\text { probleem- } \\
\text { tekst }\end{array}$ & $\begin{array}{l}\text { probleem- } \\
\text { code }\end{array}$ & $\begin{array}{c}\text { ICPC-code- } \\
\text { tabel }\end{array}$ \\
\hline Medicijnen/medicatie & + & & & \\
\hline Hulpschermen & $\stackrel{+}{+}$ & & & + \\
\hline $\begin{array}{l}\text { Gegevenswerwerking } \\
\text { (query and report) }\end{array}$ & $\stackrel{+}{+}$ & * & + & + \\
\hline
\end{tabular}

Figuur 6.1 Hulpscherm met registratie-instructie voor de huisarts.

$$
\begin{aligned}
& \text { trefwoord : HLSC } 2601 \ldots \\
& \text { BAS I S GE GEY Y N S }
\end{aligned}
$$

beroep/opleiding : 2 middelbare Horecaschool..............

psychosociaal

Bij het Registratienet Huisartspraktijken wordt altijd in de bovenste regel van dit scherm het opleidingsiveat van de patient > 25 jaar geregistreard: 1,2 of 3

Voor uitueg van de codering: toets P8

zie ook hierboven: getal ( 1,2 of 3 ) gevolgd door spatie

hierna mag voor eigen gebruik verder gespecificeerd worden.

Voor het MEMIC is dit niet nodig.

- Gegevensbewerking, een "query and report" -faciliteit

Hierdoor is het mogelijk om de vastgelegde patiënt-gegevens te bewerken. Een eigen 'procedure-taal' maakt het mogelijk voor de onervaren gebruiker om volledig transparante additionele programma's te schrijven. Deze 'procedures' kunnen via een menu of via functietoetsen opgeroepen en gestuurd worden. 
Tabel 6.2 Overwicht van de verschillende niveaus van dataverzameling.

\begin{tabular}{|c|c|c|c|}
\hline $\begin{array}{l}\text { Activiteit mb.th } \\
\text { dataverzameiting }\end{array}$ & $\begin{array}{l}\text { Software } \\
\text { hardware }\end{array}$ & $\begin{array}{l}\text { Orgatinisatorische } \\
\text { hulpmiddelen }\end{array}$ & $\begin{array}{l}\text { Ressearch- } \\
\text { faciliteit }\end{array}$ \\
\hline $\begin{array}{l}\text { Geautomatiseende } \\
\text { verilaglegging } \\
\text { bill huisarts } \\
\text { PAV } \\
\text { Journaal (teksit) } \\
\text { Probleemlijst } \\
\text { (tekst + code) } \\
\text { Medicatie } \\
\text { II } \\
\text { Dataverzamelling } \\
\text { Datacontrole } \\
\text { Correctie van } \\
\text { gegevens } \\
\text { Toetsing } \\
\text { III } \\
\text { MEMIC: opslag } \\
\text { Foutcontrole } \\
\text { Statistische } \\
\text { bewerking } \\
\text { Overzichten }\end{array}$ & $\begin{array}{l}\text { - microHis } \\
\text { - coderings- } \\
\text { ondersteu- } \\
\text { nende pro- } \\
\text { cedures }+ \\
\text { program- } \\
\text { matuur } \\
\text { - database- } \\
\text { manager } \\
\text { - microcom- } \\
\text { puter, multi- } \\
\text { user opera- } \\
\text { ting system }\end{array}$ & $\begin{array}{l}\text { - Registratie nasilag hulp } \\
\text { walarin exacte instructies } \\
\text { betreffende registratie } \\
\text { en codering- } \\
\text { - Conserisus-bevorderende } \\
\text { maatregelen } \\
\text { - instructie, communicatie } \\
\text { - instructie en ondlersteuning } \\
\text { van de systeembeheerders } \\
\text { (1 per praktijk) } \\
\text { - Hulptelefoon } \\
\text { - 'Codebode' } \\
\text { (RNH-tijdschrift) } \\
\\
\text { - instructie bij gebruik van } \\
\text { datacontrole-procedures } \\
\text { - inhoudelijke besprekingen } \\
\text { met coderende/registreren- } \\
\text { de artsen n.a.v. feedback } \\
\text { op aangeleverde data } \\
\text { - probleemlijst/commissie } \\
\text { bewaakt afspraken en } \\
\text { coördineert toetsing } \\
\text { - ophalen van data-diskettes } \\
\text { - bespreking resultaten } \\
\text { van de dataverzameling } \\
\text { leiding RNH en MEMIC }\end{array}$ & $\begin{array}{l}\text { Researchdata die } \\
\text { beschikbaar zijn } \\
\text { via de "centrale } \\
\text { index" } \\
\text { optie } 3 \text { onderzoek } \\
\text { door huisarts } \\
\text { vastgelegde pa- } \\
\text { tiêntgegevens wor } \\
\text { den gebruikt } \\
\text { optie } 4 \text { onderzoek } \\
\text { patiënt wordt per- } \\
\text { soonlijk bij on- } \\
\text { derzoek betrokken } \\
\\
\text { feedback } \\
\text { op aangeleverde } \\
\text { data ten behoeve } \\
\text { van praktijkvoering } \\
\text { ten dienste van } \\
\text { technische en } \\
\text { inhoudelijke } \\
\text { foutcontrole }\end{array}$ \\
\hline
\end{tabular}

\subsection{Organisatie dataverzameling, -bewerking en -controle}

\subsubsection{De organisatie}

In de organ"satie zijn drie niveaus to onderscheiden (zie tabel 6.2):

I geautomatiseerde verslaglegging en registratie in de computer wan de huisartspraktijk*, research binnen de registrerende praktijk.

II dataverzameling en datacontrole; research gericht op verbeterde datakwaliteit. 
II centrale dataverzameling en databewerking bij het MEMIC; research door externe onderzoekers.

Er zijn vier opties om met gegevens wit het centrale steekproefbestand onderzoek te doen:

1 Onderzoek met gegevens, die gepubliceerd zijn in de voortgangsrapportage wan het RNH. Later kan dit ook via een beschikbare set geanonimiseerde gegevens, die on-line geraadpleegd kan worden.

2 Onderzoek - na autorisatie door de Raad wan Toezicht - waarbij gebruik wordt gemaakt van de volledige set gegevens bij het MEMIC.

3 De onderzoeker wordt via de aan het MEMIC bekende sleutel verwezen naar de huisarts van betreffende patiënt: de daar in tekst (archief, computer) aanwezige patientgegevens worden bij het onderzoek betrokken.

4. Als fase 3. De patiënt zélf wordt ook bij het onderzoek betrokken via een enquête, interview of lichamelijk onderzoek.

\subsubsection{Het instrument, de toepassing}

De module 'gegevensbewerking' maakt het mogelijk om alle databestanden te benaderen via een 'Query en Report' taal. Een uitgebreide set commando's is hiervoor beschikbaar.

Alle vast te leggen data worden ondergebracht in z.g. 'gegevensgroepen", die weer opgebouwd zijn uit een aantal velden. ${ }^{13}$ (zie fig 6.3)

Meestal worden meerdere gegevensgroepen ondergebracht in eén bestand. Deze bestanden zijn rechtstreeks te benaderen via één of meerdere indexen, die door de programmatuur worden aangemaakt. Gebruikers met programmeerervaring kunnen via de module 'gegewensverwerking' eigen op maat geschreven programmatuur schrijven, de z.g. 'Pro-

Figuur 6.2 Hulpscherm voor praktijkondersteuning in de computer van de huisarts: informatie over het ziektebeeld jicht

$$
\text { trefwoord : T92.diag..... }
$$

\section{JICHT : diagnostiek}

$$
\begin{aligned}
& \text { behandeling } \rightarrow \text { T92.beh } \\
& \text { diff.diagnose } \rightarrow \text { T92.dd }
\end{aligned}
$$

\section{Disgnose: :}

Anamese is bij BO\% van de patienten typisch. Arthritis van het metatarsofalangeale gewricht van tén grote teen bij $40 \%$ Vooral acute zeer hevige pijn 's nachts: pat. kan het laken niet verdragen op de grote teen. Meestal mannen $>40$ jaar. In de helft van de gevallen gebruikt de patiënt een diureticum wit de thiazide/furosemide/etacryne/epitizide groep.

In $25 \%$ van de gevallen komt het in de familie voor.

Jicht recidiveert vaak, de tussenperiodes zijn messtal volkomen symptoomvi ij.

Onderzoek:

Arthritisbeeld met een droge huid: rood, warm, gezwollen on zeer gevoelig. Tophi komen in een later stadium en worden bij slechts bij $10 \%$ van de patienten gezien. De BSE is vaak matig verhoogd (20-40/na 1 uur). Soms koorts, leucocytose. Het urinezuurgehalte kan verhoogd $z i j n(>0.42)$. Gewrichtspunctie is soms nodig om tot een zekere diagnose the komen (urinezurkristallen in punctaat) AUT/GH 8803 
cedures" Deze procedures worden vervolgens gecompileerd en ingebouwd in de originele programmatuur. Via een functietoets of via een menustructuur kunnen ze door de gebruker geautiveerd worden (zie fig. 6.4).

Het us déze facilitelt - vanaf 1985 volledig gerealiseerd en in de praktijk toegepast die dle programmatuur zo aantrekkelijk maakte voor het registratiedoel. De aanvullende "procedures" voor databewerking, datacontrole en datacollectie konden snell in eigen beheer geschreven worden: hulp van informatici en/of systeemhuis was daarbij wel gewenst maar niet strikt noodzakelik. Het pad van analyse naar ontwerp en prototype was zo kort mogelijk.

\subsubsection{De gerealiseerde sof tware (procedures)}

Door de auteur werd de benodigde applicatie-software ontwikkeld in de vorm van een set procedures, die geautomatiseerde datacontrole en dataverzameling bij de huisarts mogelijk maken en overzichten genereren voor inhoudelijke toetsing. Deze routines controleren en verzamelen de data die elke 3 maanden op een diskette worden aangelleverd aan het MEMIC om daar ingebracht te worden in het steekproefbestand. Het veld 'updatedatum' in het patiěntregistratiescherm (zie fig. 6.4) is hierbij de indicator: door hier de actu-

Figuur 6.3 Overzicht gegevensstructuur MicroHIS-bestanden. PAT-Indexen: PATIX, PAT2X (naam en geboortedatum), WNVIX, WNV2X (straat en woonverbandnummer).

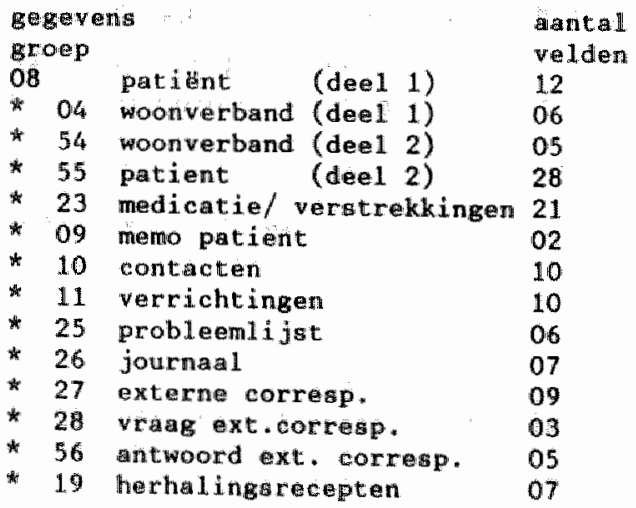

Overgenomen uit Orghidee $1: 1989 .^{13}$

Figuur 6.4 Schermbetd bij het menu warmee de huisarts de voor het RNH geschreven software (procedures) kan aanroepen.

RNH-MEMIC datacollectie MENU

1 CONTROLB-OVERZICHT lastste periode

2 POUTCONTROLE I.

3 OVBRZICHT na erste foutcorrectie

4 FOUTCONTROLE II (na correctie)

5 EILE gereedmaken voor MEMIC-diskette 
controle ch correctie worden de data "geformatteerd" en weggeschreven in een ASCII-bestand ( 2 te fig. 8 en 9). Het MEMIC zorgt voor verdere bewerking en opslag wan deze op een diskette angelewerde gegevens:

Figur 6.7 Foutcontrole bij de datacollectie: overzichu wan de ilems waarop word gecontroleerd.

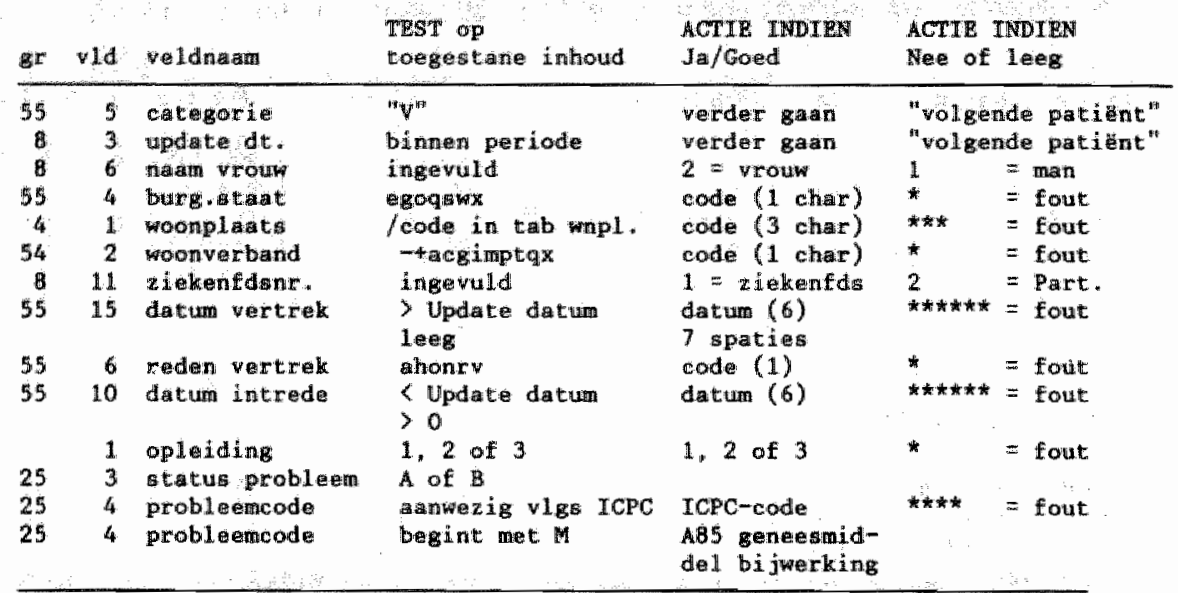

Figuuur 6.8 Voorbeeld van de inhoud van een datafile met onderzoekgegevens die door de huisarts naar het MEMIC worden verzonden.

\begin{tabular}{|c|c|c|c|}
\hline \multicolumn{2}{|c|}{ H113PHDOOO 132030657 Heerlen } & \multirow[t]{3}{*}{$\mathrm{g} 91764.18 \mathrm{p} 2$} & \multirow[t]{2}{*}{2001863221288} \\
\hline$A 820801$ & $W 11$ & & \\
\hline B.75 02 & $\mathbb{R 9 5}$ & & \\
\hline A84 03 & R97 & & \\
\hline \multicolumn{2}{|c|}{$\begin{array}{l}\text { M1113PHO000141010658E indhoven } \\
\text { TB1812 }\end{array}$} & $89176418 \mathrm{p} 2$ & 2708862081288 \\
\hline \multicolumn{2}{|c|}{$\begin{array}{l}\text { H113jJooo0152201188Heerlen } \\
\text { T890301 }\end{array}$} & $09176418 \mathrm{p} 2$ & $211188 \quad 221288$ \\
\hline \multicolumn{2}{|c|}{ M1th 13HHO000212131051Heerlen } & $9176413 \mathrm{G2}$ & 2001862200289 \\
\hline $868 \quad 01$ & $\mathrm{D8B}$ & & \\
\hline A80 02 & W13 & & \\
\hline $\mathrm{A830601}$ & $\times 99$ & & \\
\hline A871101 & H71 & & 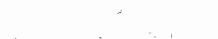 \\
\hline \multicolumn{2}{|c|}{ H14 13MMO000231241237Roermond } & 8917641762 & 2001852010289 \\
\hline $\begin{array}{l}A 860901 \\
A 901122\end{array}$ & $\begin{array}{l}\text { Lo3 } \\
\text { D01 }\end{array}$ & & \\
\hline
\end{tabular}

Thelichting Elk record begint met een aantal kenmerkende tekens (\#1\#). Hierna volgen de codes die huisarts en patiënt identificeren met behulp van een deels bij het MEMIC en deels bij de huisarts bekende sleutel. De anonimiteit wan de coor de huisarts verstrekte gegevens is op deze wijze goed gewaarborgd. Deze gegevens worden in ASCII-formaat op een diskette vastgelegd in het bestand MEMTCrni.TXT (nn = praktijknummer) . 
Figuar 6.9 Segment wit de tekst ("Misting") wan het werkgrogramma dat her bestand ME MCnnTXT admmaakt en de in figun 6.8 getoonde patientgegevens in ASCH-formaat op een diskette wastlegt.

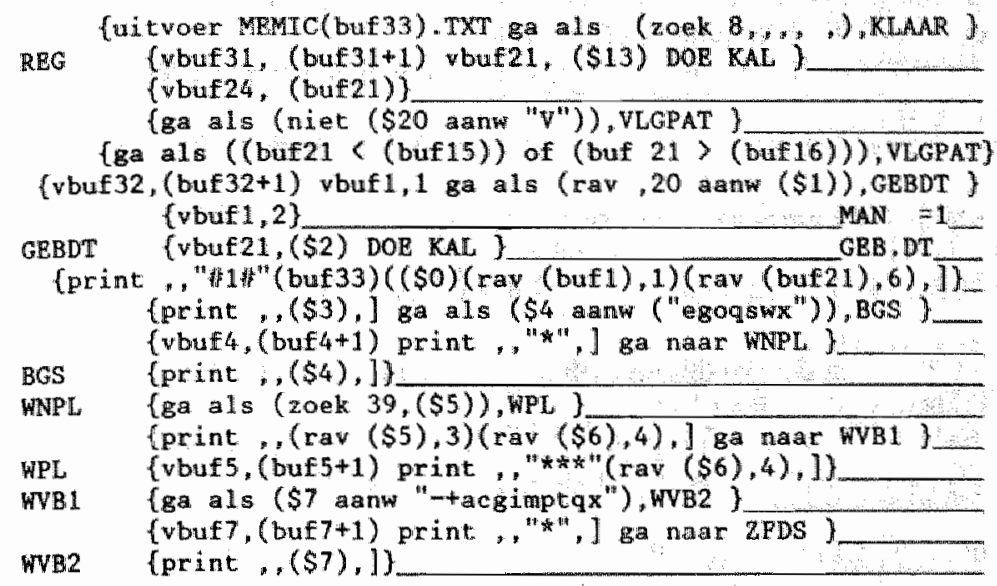

\subsection{Conclusie}

Bovenstaande uiteenzetting beschrijft een tot nu toe nog uniek huisartsgeneeskundig registratieprojekt, waarbij de mogelijkheden en voordelen van de computer in hoge mate zijn benut. Volledige automatisering van de registrerende huisartspraktijken is basis van én voorwaarde voor de opbouw van een centraal bestand. Microcomputer en mainframe, perifere automatiseerder (de huisarts) en centrale informaticus (Memic, beheerder VAXcomputer) werken in dit project hand in hand. Er wordt gebruik gemaakt van commercieel beschikbare software én van de bij een aantal huisartsen aanwezige automatiseringservaring met deze software. De perifere gebruiker kan zelf hulpprogramma's ontwikkelen woor dataverzameling en controle: bij dit project werd geen gebruik gemaakt van specialistische ondersteuning door de afdeling Medische Informatica.

Twee jaar na de start zijn in het centrale databestand van het MEMIC de gegevens van meer dan 28.672 patienten vastgelegd. Bij een verwachte doorzettende groel van het bestand met 5000 "patienten' per kwartaal wordt binnen 3 jaar het gestelde doel bereikt: een centraal steekproef-bestand met gegevens van 80.000 patiënten .

Pas na enkele jaren gebruik van het nu gecreèerde research-instrument kan definitief beoordeeld worden of het gevolgde concept technisch en inhoudelijk geslargd is, en of de computer volledig geaccepteerd wordt als hulpmiddel bij de praktijkvoering door artsen en doktersassistenten. Ook hier geldt: "the proof of the pudding is the eating".

\section{Literatuur}

1 Medisch en Maatschappelijk Informatiecentrum (MEMIC) Caseregisters als steekproefkaders Maastricht Rijksuniversiteit Limburg, 1989.

2 Springer MP, Slager NN, Perk MA van. Waarom automatiseren in de huisartspraktijk? 
MC 1984; 39, 813-4.

3 Botman I. Automatseren in de huisartspraktijk. MC 1984; 39, 1291-5.

4. Bemmel JH wan. Mensen, communicatie en computers in de geneeskunde. Bijdrage aan het $37 \mathrm{e} \mathrm{KNMG} \mathrm{ledencongres} \mathrm{in} \mathrm{Heerlen.} \mathrm{MC} \mathrm{1984;} 39,1487-92$.

5 Eijk J wan. Automatisering en wetenschappelijk onderzoek: een paar apart? Amsterdam VU 1985; Symposium "De computer un de praktijk".

6 Bemmet JH van, Willems JL. Handboek Medische Infornatica Utrecht 1989; Bohn Scheltema Holkema.

7 Horst J van der. Gezondheid en nien werken [Dissertatie]. Maastricht Rijksuniversitteit Limburg, 1988.

8 Werkgroep Coördinatie Informatie Automatisering. Declamed en microHIS. Huisarts Wet 1986; (30-3), 84-5.

9 Nederlinds Huisartsen Genootschap. Toetsing Elias voltooid. Huisarts Wet 1988: (31-9), $84-5$.

10 Nederlands Huisartsen Genootschap. Invoering van automatisering door Hüisartsen. Rapportage Nutprojekt 1987; deel 1 en 2.

11 Krutzen FM. Huisarts Informatie Systeem (HIS); Onderzoek naar automatiseringsmogelijkheden in de huisartspraktijk. Rapport 1985, deel 1, Nr. 850217, Ministerie van WVC.

12 Werkgroep Coôrdinatie Informatie Automatisering (WCIA). Referentiemodel Huisarts Informatie Systeem, Versie 3. Utrecht Nederlands Huisartsen Genootschap, 1986.

13 Structuur MicroHis-bestanden. Bellekom R. Orghidee 1989; 1. 


\section{Het Registratienet Huisartspraktijken getest I}

De geautomatiseerde medische registratie wordt getest in 2 onderzoeken. Dit hoofdstuk beschrijft een oriënterend onderzoek in 11 huisartspraktijken van het RNH. Het betreft hier de regulatie van de bloedsuiker bij door de huisarts gecontroleerde patiënten met een diabetes mellitus type II. Het hoofddoel van dit onderzoek is het vinden van een antwoord op de volgende vraag: "wat is de meerwaarde van geautomatiseerde medische registratie in de huisartspraktijk bij kwaliteitsbewaking?' De gebruikte onderzoekmethode, waarbij de computer zo veel mogelijk werd ingeschakeld bij de dataverzameling, leidde snel tot een duidelijk antwoord op de vragen die werden gesteld over de bloedsuikerregulatie. De belasting van de aan dit onderzoek meewerkende huisartsen en praktijken was minimaal, de medewerking was maximaal. Geautomatiseerde registratie wan probleemlijsten, zoals toegepast in de RNH-praktijken, maakt gegevens over chronische aandoeningen en risicofaktoren gemakkelijk toegankelijk voor onderzoek, kwaliteitsbewaking en toetsing.

\subsection{Inleiding}

In de hoofdstukken 5 en 6 is beschreven hoe de geautomatiseerde praktijken binnen het Registratienet Huisartspraktijken van de Rijksuniversiteit Limburg (RNH) te werk gaan. In dit hoofdstuk wordt een toegepast onderzoek met betrekking tot de kwaliteit van zorg beschreven. Dit onderzoek werd uitgevoerd in de geautomatiseerde huisartspraktijken, die zijn verbonden aan het RNH. Na bespreking van de resultaten zal bekeken worden of automatisering van de medische registratie het verrichten van onderzoek op het gebied van de kwaliteit van zorg vergemakkelijkt en efficiënter maakt.

In 1989 heeft het Nederlands Huisartsen Genootschap (NHG) de "Diabetes Mellitus Type-II NHG-Standaard' geformuleerd. 'Herin wordt onder andere gesteld, dat bij het behandelen wan een diabetes mellitus type II (ook wel genoemd 'niet insuline afhankelijke diabetes ${ }^{2}$ ) een nuchtere bloedsuikerwaarde $>8 \mathrm{mmol} / \mathrm{l}$ en een bloedsuikerwaarde 2 uur na belasting $>10 \mathrm{mmol} / \mathrm{l}$ niet aanvaardbaar is.

In het verleden is al vaker onderzoek gedaan naar de bloedsuikerwaarde en instelling van diabetes mellitus type II patiënten die gecontroleerd werden door de Nederlandse huisarts. ${ }^{34}$ Steeds vaker wordt er in publicaties op gewezen dat ook bij Diabetes mellitus type II patiënten een goede bloedsuikerregulatie de levensduur verlengt en complicaties uitstelt of zelfs voorkomt. ${ }^{2}$ De introductie van de nieuwe $\mathrm{NHG}$-standarard is een extra motief voor veel huisartsen om in de toekomst meer aandacht te besteden aan deze groep diabeten.

Dit hoofdstuk werd eerder - in een aangepaste versie - gepubliceerd als: Hoppener P, Knotnerus JA. Gtol R. Praktijkautomatisering en kwaliteitsbewaking. De bloedsuikerregulatie bij pariènten met diabetes mellitus type II onderzocht in het Registratienet Huisartspraktijken. Huisarts Wet 1990; 33(10): 390-3. 
Het is imteressant om juist op dit moment een beeld te krijgen van de stand van zaken betreffende de bloedsuikerregulatie van patienten met cen diabetes mellitus type II in een aantal huisartspraktijken. Er werd derhalve een onderzoek verricht in 11 RNH-praktijken orm een antwoord te krijgen op de volgende vragen:

- Hoeveel procent van de patiënten met een diabetes mellitus type II die door de huisants worden gecontroleerd is 'niel goed' ingesteld?

- Kan op grond van het uitgevoerde onderzoek en van de resultaten geconcludeerd worden, dat automatisering van de medische registratie bij de huisarts onderzoek op het gebied van de kwaliteit van zorg versnelt, faciliteert en efficiênter maakt?

\subsection{Methode}

De onderzoekmethode wordt in figuir 7.1 verduidelijkt aan de hand van een schema. In juni 1989 bevatte het centrale databestand, het 'huisartsregister' bij het MEMIC, de gegewens wan 9834 patiënten (zie hoofdstuk 5). Uit dit databestand worden gegevens verzameld betreffende alle patiènten met een ICPC-code T90: dat wil zeggen alle patiènten met een of andere vorm van diabetes $(n=306)$.

Figuur 7.1. Schema onderzoek naar diabetes mellitus type II in de RNH-praktijken.

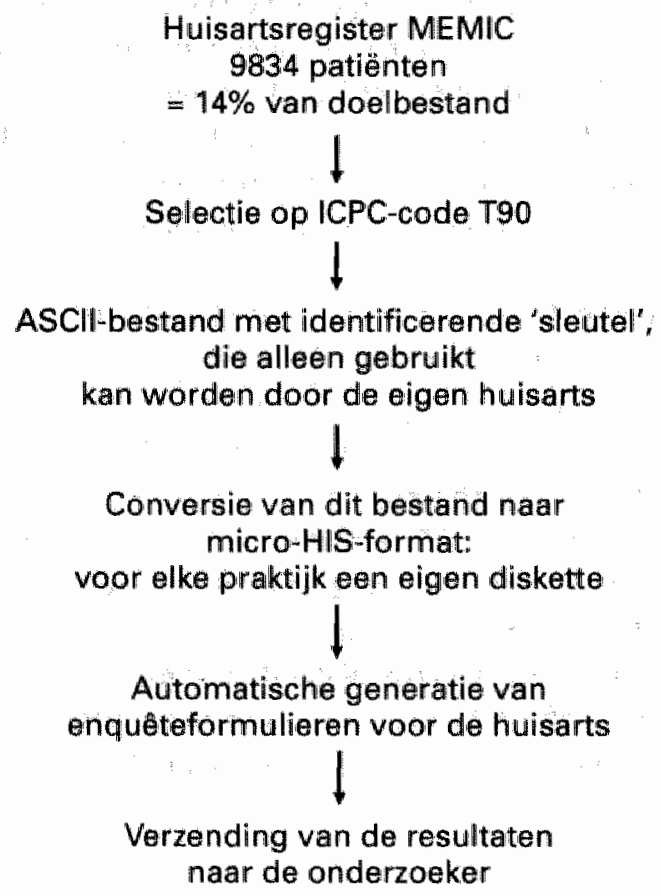


De onderzoeker (PH) krijgt vervolgens wan het MEMIC een diskette met een ASCI-be stand warin de volgende gegevens van de geselecteerde patiènten zijn vastgelegd: code praktijk, patiëntnummer (toegekend door het Huisarts Informatiesysteen in betreffende praktijk), geboortedatum en geslacht.

Via een yoor dit doel in Basic geschreven programma worden deze gegevens per praktijk geselecteerd en geconverteerd tot een formaat, dat door het microHIS programma bij de huisarts ingelezen kan worden. Vervolgens wordt naar elke praktijk een diskette verzonden met het aangemaakte databestand en de benodigde software (microHIS-procedures, zie hoofdstuk $5 \mathrm{~b}$ ). Indien de systeembeheerder van de betreffende RNH-praktijk de bijgevoegde instructies goed uitvoert drukt de printer een enquête-formulier af (zie fig. 7.2\%.

Op de linkerkant van het formulier worden de identificerende, en dus privacy-gevoeli-

Figuur 7.2 Voorbeeld van een door de printer afgedrukt onderzoeksformulier met fictieve persoonsgegevens. De privacy-gevoelige gegevens (links) kurnen worden afgeknipt woardat de onderzoeksgegevens worden verzonden.

\begin{tabular}{|c|c|c|}
\hline Informatie over Problleem & $\therefore \mathrm{CODE}$ & \\
\hline Informatie over de Patidnt & Leefti $j \mathrm{~d}$ & NR \\
\hline $\begin{array}{l}\text { Geb dt: } 300301 \\
\text { Janssen-Bakhbier JN }\end{array}$ & $\begin{array}{l}\text { T90 A } 6702 \quad 88 \\
\text { Diabetes IT dieet en Rasti } \\
\text { Tneuline J/N? }\end{array}$ & inon $1 \mathrm{dd}$ \\
\hline Indien geen insuline $=\Rightarrow$ & 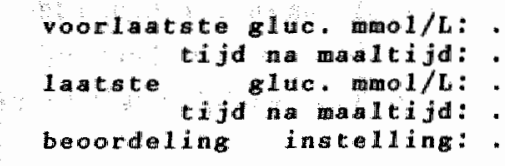 & $\begin{array}{l}\cdots \cdots \\
\cdots \cdots \\
\cdots \cdots \\
\cdots \cdots \\
\cdots \cdots\end{array}$ \\
\hline $\begin{array}{l}\text { Geb de: } 120702 \\
\text { Kalselis pH }\end{array}$ & 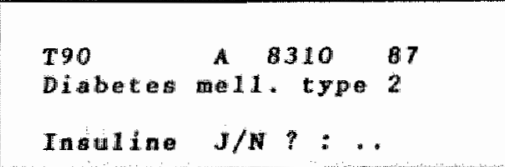 & 02 \\
\hline Indien geen thaline $==$ & 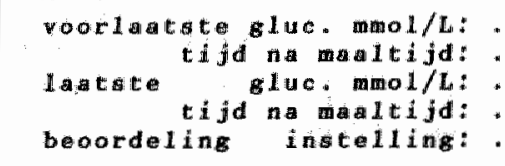 & $\begin{array}{l}\ldots \ldots * \\
\cdots \cdots \\
\ldots \cdots \\
\ldots \cdots \\
\cdots \cdots\end{array}$ \\
\hline $\begin{array}{l}\text { Geb dt: } 241237 \\
031224 \\
\text { Vermouten-KIabbeek BHJ }\end{array}$ & $\begin{array}{l}\text { T9o A } 7511 \text { SL } \\
\text { Diabetes } T \text { controle door in } \\
\text { Tnatine } J / N ?: \ldots\end{array}$ & nternist \\
\hline Indien geen insuline $=$ ? & 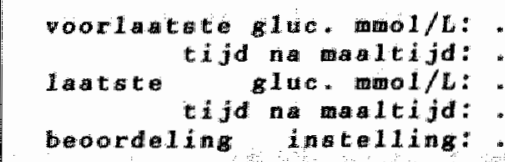 & $\begin{array}{l}\cdots \cdots \\
\cdots+\cdots \\
\cdots \cdots \\
\cdots \cdots \\
\cdots \cdots\end{array}$ \\
\hline
\end{tabular}


ge patientgegevens afgedrukt, zodat deze voór het terugzenden van de enquête genakkelijk (met een schaar) verwijderd kunnen worden. Op de rechterkant van het formulier worden bovenaan enkele gegevens afgedrukt die van belang zijn voor de onderzoeker: de ICPC-code (in dit geval altijd T90), de status van het probleem $(A=$ actief, $B=$ blind/inactief), jaar en maand waarin het probleem actief is geworden (bijwoorbeeld 6702), de leeftijd van de patiènt en het rangnummer van het enquêteformulier. Hieronder wordt de door de huisarts in de computer vastgelegde toelichting bij het gecodeerde probleem, de "tekst van de probleemregel", weergegeven. Bijvoorbeeld: "Diabetes II en Rastinon Idd". Pas dan komen de enquete vragen:

Insuline gebruik $\mathrm{J} / \mathrm{N}$...

en indien geen insuline-gebruik (N)

Voorlaatste glucose mmol/: .....

hoe lang na de maaltijd: .....

Laatste glucose mmol/l: .... hoe lang na de maaltijd: .....

Persoonlijke beoordeling van de instelling:

Nadat de huisartsen de betreffende patiëntgegevens hebben opgezocht en de vragen zijn ingevuld wordt de rechterkant wan het formulier opgestuurd naar de onderzoeker.

De angeleverde resultaten worden dan door de onderzoeker handmatig verwerkt en bewerkt; dit geldt ook woor de statistische toetsen. Gebruikt werden de chikwadraat-toets voor ongepaarde waarnemingen en Cohen's Kappa voor interwaarnemer overeenstemming.

De persoonlijke beoordeling van de huisarts over de instelling van de bloedsuikers word vergeleken met het oordeel van de onderzoeker $(\mathrm{PH})$ over de bloedsuikerregulatie. Het hierbij door de onderzoeker gehanteerde criterium is zeker niet te streng: wanneer de gemiddelde waarde van de laatste 2 gemeten bloedsuikers bij een patiënt boven de 10 mmol/l liggen (nuchter en niet nuchter) dan wordt dit door de onderzoeker beoordeeld als "niet goed' ingesteld (verder genoemd: "het $10+$ criterium").

\subsection{Resultaten}

Bij de beoordeling van de resultaten werd eerst gezocht naar een antwoord op de vraag. "hoeveel procent van de patiënten met een diabetes mellitus type II die door de huisarts worden gecontroleerd is niet goed ingesteld volgens het $10+$ criterium?" Omdat het tijdstip waarop de patient was geprikt vaak niet bekend was en/of niet ingevuld is dit gegeven niet bij het onderzoek betrokken.

De resultaten van de enquête zijn weergegeven in de tabellen $7.1-7.4$.

Bij 19 wan de 197 patiënten met een diabetes mellitus type II waren geen bloedsuikerwaarden bekend omdat ze door de internist in het ziekenhuis werden gecontroleerd. Voorzover kon worden nagegaan via de op het enquêteformulier afgedrukte "tekst van de probleemregel" en een schriftelijke follow-up werden 7 patienten uit deze groep door de internist behandeld met lnsuline.

De overige 178 diabetes-II patiënten werden gecontroleerd door de huisarts. Hiervan kregen er 3 insuline, de overige patiẻnten gebruikten orale antidiabetica en/of volgden een dieet. Bij $112(63 \%)$ van deze 178 diabetes mellitus type II patiënten was de bloed- 
Tabell 7.1 Bloedwikerregulatic bij diabetes mellitus type I patienten. Vergelihing wan de "75 phus"-groep met de "75 min'-groep.

\begin{tabular}{|c|c|c|c|c|}
\hline \multirow{3}{*}{$\begin{array}{l}\text { Beoordelling instelling } \\
\text { volgens criterium }\end{array}$} & \multicolumn{4}{|c|}{ Diabetes mellitus type ll patiänten. } \\
\hline & \multicolumn{2}{|c|}{$75+\mathrm{ur}$} & \multicolumn{2}{|c|}{$<75$ har } \\
\hline & $n=56$ & $100 \%$ & $n=122$ & $100 \%$ \\
\hline goed & 34 & $61 \%$ & 78 & $64 \%$ \\
\hline niet goed & 22 & $39 \%$ & 44 & $36 \%$ \\
\hline
\end{tabular}

Toelichting Indien de gemiddelde waarde van de laatste 2 gemeten bloedsuikers bij een patuënt boven de $10 \mathrm{mmol} / \mathrm{l}$ lagen dan werd de instelling als 'slecht' beoordeeld.

Tabel 7.2 Bloedsuikerregulatie bij diabetes mellitus type II patënten. Overzicht per praktijk.

\begin{tabular}{lcccc}
\hline $\begin{array}{l}\text { Volgnr praktijk } \\
\text { praktijk }\end{array}$ & \multicolumn{2}{c}{ Beoordeling huisarts } & \multicolumn{2}{c}{ Beoordeling onderzoeker } \\
\cline { 2 - 5 } & $\begin{array}{c}\text { goed } \\
n=120\end{array}$ & $\begin{array}{c}\text { niot goed } \\
n=58\end{array}$ & $\begin{array}{c}\text { goed } \\
n=112\end{array}$ & $\begin{array}{c}\text { nlet goed } \\
n=66\end{array}$ \\
\hline 1 & 6 & 6 & 6 & 6 \\
2 & 6 & 3 & 6 & 3 \\
3 & 6 & 10 & 6 & 10 \\
4 & 13 & 0 & 13 & 0 \\
5 & 16 & 13 & 16 & 13 \\
6 & 20 & 4 & 14 & 10 \\
7 & 2 & 1 & 3 & 0 \\
8 & 5 & 3 & 5 & 3 \\
9 & 11 & 9 & 14 & 6 \\
10 & 18 & 7 & 19 & 6 \\
11 & 17 & 2 & 10 & 9
\end{tabular}

Toelichting De volgorde van de praktijken in deze tabel is willekeurig gekozen.

Wanneer de gemiddelde waarde van de laatste 2 gemeten bloedsuikers bij een patiënt boven de $10 \mathrm{mmol} / \mathrm{lag}$, dan werd de instelling als "slecht' beoordeeld (het " $10+$ ' critorium).

Tabel 7.3 Persoonlijke beoordeling wan de bloedsuiker regulatie door de eigen huisarts vergeleken met beoordeling volgens het '10+' criteriwn. Kappa $=0.78$.

\begin{tabular}{|c|c|c|c|c|}
\hline & & \multicolumn{2}{|c|}{ Beoordeling door eigen huisarts } & \\
\hline & & 'goed" & "niet goed" & \\
\hline \multirow{2}{*}{$\begin{array}{l}\text { Beoordeling } \\
\text { volgens } \\
\text { het ' } 10+\text { ' criterium }\end{array}$} & 'goed' & 107 & 5 & 112 \\
\hline & 'niet goed' & 13 & 53 & 66 \\
\hline & & 120 & 58 & 178 \\
\hline
\end{tabular}


Tabel 7.4 Samenstelling wan de groep patietren die in het centrale bestand bij het MEMIC gevonden werden bij een selectie op ICPC code T90. $N=306$.

Gegevens niet beschikbaar 7

Inmiddels overleder.

Zwangerschapsdlabetes

Geen diabetes, eenmalig hoge bloedsuiker 9

Diabetes mellitus type ! (insuline afhankelijk) 50

Diabetes melltus type II (niet insuline afhankelik)

- geen bloedwaarde bekend (controle internist) 19

- loedsuikerwaarden bekend

Pelldatum voor de gegevens in het MEMIC-bestand is 1 juni 1989. De enquate werd doar de artsen ingevuld in de maanclen september en oktober 1989.

suikerwaarde "goed" ingesteld, bij 66 patiẻnten (37\%) was de instelling volgens het gehanteerde criterium 'niet goed'.

Tabel 7.1 laat zien dat 56 diabetes mellitus type $\mathbb{I}$ patienten ouder dan 74 jaar waren Bij $34(61 \%)$ patiënten uit deze groep bejaarden waren de bloedsuikers 'goed. gereguleerd. $\mathrm{Bij} 22(39 \%)$ patiënten uit deze leeftijdsgroep was de instelling "niet goed'. Dit betekent dat er geen significant verschil is gevonden tussen de bloedsulkerregulatie bij " 75 plus"-groep en de "75 min"-groep (chikwadraat; significantiedrempel $\mathrm{p}=0.05$ ).

Tabel 7.7 geeft een overzicht van de resultaten per praktijk. Tabel 7.3 laat de verschillen zien tussen de persoonlijke beoordeling van de bloedsuikerregulatie door de huisarts en de beoordeling volgens de bij dit onderzoek geformuleerde criteria. Er is een goede overeenstemming $(\mathrm{kappa}=0.78)$.

Enkele systeembeheerders hadden problemen bij het inlezen van de diskette: deels viel dit te herleiden tot een onduidelijkheid in de gegeven instructie, deels tot problemen bij het werken met de software. Dit kwam met name voor bij enkele ervaren computergebruikers omdat ze de gegeven instructies niet letterlijk opvolgden.

De verdere verwerking van de geautomatiseerde enquête verliep probleemloos. De systeembeheerders hadden 40 tot 60 minuten nodig voor het inlezen van de diskette en het activeren van de software. De artsen hadden, afhankelijk van het aantal patiènten, in totaal 10 tot 60 minuten nodig voor het opzoeken van de patiënten-dossiers en het beantwoorden van de enquete-vragen.

\subsection{Beschouwing en conclusie}

Een in verband met de opbouw van het bestand wellicht niet representatieve steekproef van 9834 patiënten uit 11 RNH-praktijken werd onderzocht met als vraagstelling: hoeveel procent van de in dit bestand bekende diabetes mellitus type II patiënten zijn 'niet goed" ingesteld. Deze vraag kon duidelijk beantwoord worden: $37 \%$ van de diabetes type II patiënten, van wie de 2 laatste bloedsuikerwaarden bekend waren, was 'niet goed' in- 
gesteld (gemiddelde van de laatste 2 gemeten bloedwarden $>10 \mathrm{mmol} / \mathrm{M}$ ). Ten tajde van het onderzoek was de standaard "Diabetes mellitus type II van het NHG al bekend.

Ondanks de beperkingen in representativiteit en omvang van de steekproef zyn et in tabel 2 grote verschillen te zien in de per praktijk gerealiseerde bloedsuikerregulatie. Deze bevinding is waarschijnlijk te verklaren als een positief effect wan het actieve diabetes-beleid dat in een aantal RNH-praktijken wordt gevoerd.

In tabel 3 komt duidelijk naar voren, dat de meeste artsen zich er goed wan bewust zijn, dat ze bij een aantal patiènten de gevraagde kwaliteitsnorm (nog) niet gehaald hebben.

Gezien deze resultaten, maar meer nog gezien het anonieme karakter van de gegevensverwerking de gegroeide routine binnen het RNH en het belang dat men heeft bij een open toetsing, gaan we er van uit dat de door de lhussarts verstrekte gegevens betrouw: baar zijn.

De extra inspanning die bij dit onderzoek werd gevraagd van de deelnemende artsen en praktijken was gering. Geconcludeerd mag worden dat de onderzokksgegevens snel en op zeer efficiënte wijze vergaard konden worden. De geautomatiseerde probleemregistratie in de perifere praktijken en de centrale dataopslag van de gegevens bij het MEMIC makten dit mogelijk.

De vraag die bij dit onderzoek werd gesteld kan in een niet geautomatiseerde praktijk alleen op korte termijn beantwoord worden wanneer een apart registratiesysteem voor diabetespatiënten wordt bijgehouden, bijvoorbeeld op de speciaal voor dit doel ontworpen kaarten van het NHG die in een aparte kaartembak worden bewaard.

De in dit hoofdstuk beschreven opsporingsmethode kan in een geautomatiseerde praktijk worden toegepast bij onderzoek naar alle chronische aandoeningen en risico-faktoren die zijn gecodeerd en geregistreerd in de probleemlijst.

Indien ook alle contacten geregistreerd en gecodeerd waren zou een volledig geautomatiseerde en dus huisartsonafhankelijke onderzoekprocedure mogelijk zijn geweest. Binnen het RNH is niet voor deze methode gekozen omdat het systematisch actief coderen van alle contacten een enorme en niet kosteneffectieve werkbelasting voor de participerende artsen met zich meebrengt.

Ook werd niet gekozen voor het alternatief, het gebruik van een 'data-dictionary'. Een dergelijke "verplichte woordenschat", waarbij elk toegestaan woord is gekoppeld aan een code, wordt reeds toegepast bij het "VAMP"-project in Engeland. "

De methodologische aspecten van deze wijze van dataverzameling zijn nog onvoldoende onderzocht. Afvlakking van de in het "journal' beschikbare huisartsgeneeskundi ge informatie is wellicht het grootste probleem hierbij, want de huisarts wordt in meerdere of mindere mate belemmerd in zijn expressiemogelijkheden. ${ }^{67}$ De beschrewen methode kan ook door de huisarts zelf voor de eigen praktijk worden toegepast en is aldus een krachtig middel voor zelftoetsing aangepast an de specifieke prioriteiten per praktijk. Ook intercollegiale uitwisseling en toetsing kan via deze methode een nieuwe dimensie krijgen.

Het voordeel van de bij het hierboven beschreven onderzoek gevolgde methode is deit de huisarts zelf actief meewerkt aan het onderzoek. Hij verschaft zonodig aanvullende contextuele informatie en is tegelijkertijd betrokken bij een vorm van 'zelftoetsing'. Daarnaast is de belasting van huisarts en praktijk niet groot. 
Bij het in dit hoofdstuk beschreven onderzoek komt duidelijk naar voren dat de praktijkcomputer, indien hij ook wordt gebruikt als hulpmiddel bij de medische verslaglegging, een belangrijke rol kan spelen bij patièntgebonden onderzoek, bij de kwaliteitsbewaking en bij intercollegiale toetsing.

\section{Literatuur}

1 Nederlands Huisartsen Genootschap. Diabetes Mellitus Type II (Standaard). Huisarts Wet 1989;32:15-8.

2 Heine RJ. Insulin treatment of non-insulin dependent diabetes mellitus. Ballière's Clinical Endocrinology and Metabolism 1988; 2 (5): 477-92.

3 Weel C van, Zelst PAM van. Diabetes Mellitus in een huisartspraktijk II. Huisarts Wet $1983 ; 26: 214-7$.

4 Rutten GEHM, Eijk JTM van, Beek MML, Velden HGM van der. De type II diabeet: hoe staat het ermee? Een explorerend onderzoek in acht huisartspraktijken. Huisarts Wet 1988: 31: 124-9.

5 Hall GC, Luscombe DK, Walker SR. Post-marketing surveillance using a computerised. General Practice database. Pharmaceut. Med. 1988; 2: 345-51.

6 Knottnerus JA (editor). Seminar on Clinical Epidemiology and Health Care. Research. A meeting with Prof. Dr. Alvan R. Feinstein. Book of abstracts. Maastricht University of Limburg january 1989.

7 Feinstein AR. Consultatie RNH-project (persoonlijke mededeling). Maastricht; januari 1989. 


\section{Het Registratienet Huisartspraktijken getest II}

Dit hoofdstuk beschrijt hoe een onderzoek werd verricht naar de registratie van de diagnose kanker bij het Registratienet Huisartspraktijken van de Rijks-universiteit Limburg (RNH) en bij de regionale kankerregistratie van het Integraal Kankercentrum Limburg. (IKL) Het betreft een proefstudie die als model kan dienen voor een vervolgonderzoek. Naar aanleiding van de resultaten van dit onderzoek kunnen slechts voorlopige conclusies worden getrokken, want beide registratie. systemen verkeren nog in de opbouwfase. Gesteld kan worden dat het aantal 'echte missers' in dit stadium bij beide registraties acceptabel is $(+5 \%)$. RNH en IKL lijken elkaar te kunnen aanvullen: het RNH kan de blinde viekken bij het IKL zichtbaar maken en vice versa. Bij het RNH werden 8 registratiefouten gevonden bij de 272 onderzochte registraties. Bij het IKL was slechts een registratie niet correct, zoals valt te verwachten bij een specifieke registratie. Het lijkt zinwol on dit onderzoek te herhalen wanneer beide bestanden hun definitieve vorm hebben gekregen.

\subsection{Inleiding}

Gegevens die verstrekt worden door het Pathologisch Anatomisch Landelijk Geautomatiseerd Archief (PALGA) vormen de basis voor de Regionale Kankerregistratie. Een tweede bron zijn de ontslaggegevens uit de regionale ziekenhuizen, verkregen uit de overzichten van de Landelijke Medische Registratie (LMR). "Andere bronnen, zoals huisartsen en verpleeghuisartsen, leveren vooralsnog geen gegevens aan voor dle regionale kankerregistratie. Met name zal de groep poliklinische patienten waarbij de diagnose kanker is gesteld op anderen gronden, zoals het klinisch beeld of een röntgenfoto, niet vertegenwoordigd zijn in de huidige regionale kankerregistratie.

Ditzelfde geldt ook voor een kleine groep patiënten die buiten de regio, soms zelfs in het buitenland, zijn onderzocht en behandeld. En dan is er nog een catagorie patienten die niet wordt verwezen naar de tweede lijn.

De via de Landelijke Kankerregistratie verzamelde incidentiecijfers geven een veel be trouwbaarder beeld ower het voorkomen van kanker dan de voorheen beschikbare getallen uit de sterftecijfers van het $\mathrm{CBS}^{2}$ De bruikbaarheid van de huidige landelijke kankerregistratie wordt mede bepaald door de volledigheid en betrouwbaarheid van de regionaal geregistreerde gegevens. Ook is het vak van belang om op regionaal niveau beleids-ondersteunende gegevens te krijgen over incidentie en prevalentie van kanker (Nota $2000 \mathrm{WVC}^{3} .^{34}$ Een op zichzelf klein hiaat in de locale registratie kan dan toch nog een grote betekenis hebben.

Tot nu toe is nog niet vastgesteld of en hoe de medische registratie bij de huisarts op overtuigende wijze een dergelijk hiaat zichtbaar kan maken. Ook zijn geen eensluidende 
cijfers bekend over de grootte van een eventueel bestaunde "blinde wlek" ${ }^{5-7}$ Anderzijds is ook niet bekend hoe volledig en betrouwbaar de gegevens zijn die door de huisartsgeneeskundige registraties worden vastgelegd.

Dit hoofdstuk levert een bijdrage aan een verdere discussie hierover. Het beschrijft een onderzoek waarbij wordit nagegan of alle bij een aantal geautomatiseerde huisartspraktjken bekende kankerpatienten ook als zodanig staan geregistreerd bij de Regionale Kankerregistratie. Bij dit onderzoek worden de databestanden van het Registratie Net Huisartspraktijken (RNH) wan de Rijksuniversiteit Limburg en van het Integraal Kankercentrum Limburg (IKL) met elkaar vergeleken. De resultaten van deze vergelijking worden

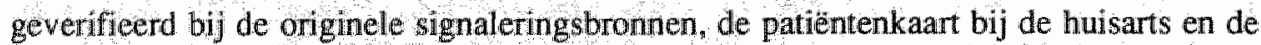
ziekenhuisstatus. Op deze wijze hopen wij een voorlopige indruk te krijgen van de volledigheid en betrouwbartheid van de door het RNH en door het IKL geregistreerde gegevens. Mogelijk zullen we ook een schatting kumnen maken van de grootte van de voornoemde "blinde ylek".

Dit onderzoek is opgezet als een proefstudie die als model kan dienen voor een vervolgonderzoek op een later tijdstip, wanneer beide databestanden hun definitieve vorm hebben gevonden. Op het moment van de bestandskoppeling waren beide bestanden nog in de opbouwfase.

\subsection{Patiënten en methoden}

\subsubsection{Patienten}

De onderzoekgegevens zijn afkomstig uit twee registratiesystemen die gegevens vastleggen betreffende patiënten die wonen in Zuid Limburg, te weten:

\section{De regionale kankerregistratie wan het IKL}

De kankerregistratie van het IKL omvat de regio's Zuid-en Midden-Limburg: een gebied met ongeveer 851.000 inwoners. De IKL-registratie is in 1982 gestart. Aanvangsdatum van de effectieve registratie bij het IKL is 1-1-1986. Vanaf die datum is medewerking van alle ziekenhuizen in de IKL-regio verkregen, zodat het IKL in staat is regionale kankerincidentie-cijfers vanaf $1-1-1986$ te presenteren.

In 1986 registreerde het IKL 3161 nieuwe primaire maligniteiten. ${ }^{8}$ Belangrijke signaleringsbronmen zijn de pathologen-anatomen en de medische registraties van de ziekenhuizen. Aan de hand wan de poliklinische en/of klinische status worden de gegevens geconpleteerd door de daartoe opgeleide registratiemedewerkers. ${ }^{9}$ Conform de richtlijnen van de landelijke kankerregistratie worden basaalcelcarcinomen van de huid niet geregisw treerd.

Per 1-10 1989, de pelldatum voor het IKL bij dit onderzoek, bevatte dit bestand gegevens betreffende 16.132 patiënten met én of meerdere primaire maligne tumoren.

\section{Het hwisartsregister van het RNH}

Het RNH bouwt onder leiding van de vakgroep huisartsgeneeskunde van de Rijksuniversiteil Limburg een databestand op met gegevens van patiënten uit een aantal Limburgse huisartspraktijken. Dit databestand wordt beheerd door het Medisch en Maatschappelijk. 
Informatiecentrum van de Rijksuniversiteit Limburg (MEMIC). Het bevat alleen gegevens van patiënten waarbij de achtergrondvariabelen en probleemlijsten compleet zijn in. gevuld. De gang van zaken bij het RNH wordt beschreven in hoofdstuk 5.

Bij thet nu beschreven onderzoek werden alleen RNH-praktijken uit de IKL-regio betrokken: het betreft hier 9 praktijken met ongeveer in totaal 68000 patiënten. Drie van deze praktijken registreren voor het RNH vanaf $1-5-1988,6$ praktijken zijn een half jaar later hiermee begonnen. Ten tijde van het onderzoek (peildatum 1-7-1989) bevalte dit bestand gegevens van 9627 patiënten, waarvan er 236 bekend waren met een primair maligne tumor. Maligniteiten die vóór de aanvang van de registratie reeds bekend waren wor den retrospectief als 'probleem' geregistreerd. Bij het coderen van de geregistreerde maligniteiten wordt gebruik gemaakt van de International Classification of Primary Care (ICPC).

\subsubsection{Methoden}

Het vergelijkend onderzoek van beide databestanden werd gefaseerd uitgevoerd.

\section{Fase 1 - het 'matchen' van beide bestanden.}

In october 1989 werden beide bestanden met elkaar vergeleken. Tabel $8 . I$ geeft een overzicht van de gemeenschappelijke identificerende parameters in beide bestanden.

In 1988 is door het IKL en de vakgroep epidemiologie van de Rijksuniversiteit Limburg een onderzoek uitgevoerd om na te gaan op welke wijze de kankerregistratie gebruikt kan worden voor koppeling met andere onderzoekbestanden. Een optimale koppeling kon worden uitgevoerd door gebruik te maken van de gegevens: geboortedatum, geslacht en eerste 4 letters van de familienaam. Vervolgens was het mogelijk om met een aantal aanvullende gegevens en enkele beslisregels het geringe aantal fout positieve koppelingen te elimineren.

Het gegeven 'familienaam' is echter bij deze koppeling niet beschikbaar in het RNHbestand. Een koppelingssleutell bestaande uit geboortedatum, geslacht en cijfers van de postcode bleek ook een grote voorspellende waarde te hebben, met een iets groter aantal fout-positieve koppelingen. ${ }^{10}{ }^{11}$ Hierbij moet worden opgemerkt dat het gegeven 'postcode' door verhuizing kan veranderen waardoor het aantal gemiste koppelingen na verloop

Tabel 8.1 Voor: "matching" beschikbare gegevens. Percentages.

\begin{tabular}{lccc}
\hline & RNH & $\begin{array}{c}\text { IKL-bestand } \\
\text { alle registraties }\end{array}$ & $\begin{array}{c}\text { IKL-bestand } \\
\text { alleen volledige } \\
\text { registraties (1986) }\end{array}$ \\
\hline Geboortedatum & 100 & 100 & 100 \\
Geslacht & 100 & 100 & 100 \\
Postcode (4 pos.) & 98 & 91 & 100 \\
Woonplaats & 100 & 95 & 100 \\
Geboorteplaats & 97 & 37 & 42 \\
Naam huisarts & 100 & - & - \\
Naam (PA-)specialist & - & 100 & 100 \\
\hline
\end{tabular}


yan tijd groter zal worden. Bij het RNH zal na verhuizing de postcode meestal worden aangepast, bij het IKL gebeurt dit alleen bij een meuwe registratie. Daar echter het tijdsverloop tussen registratie bij het IKL en de witwoering van de koppeling kort was is toch gebnuk gemaakt van deze koppelingssleutel.

Voor de verificatie van de juistheid wan de gesignaleerde koppelingen kon gebruik worden gemaakt van de gegevens: geboorteplalats, kankerdiagnose en incidentiedatum.

\section{Fase 2 - het indelen van de onderzoekdata in groepen}

Het is nu mogelijk om de gegevens uit de 2 bestanden in te delen in een viertal groepen, zoals weergegeven in onderstaande kruistabel.

\begin{tabular}{c|c|c|c}
\multirow{2}{*}{} & & \multicolumn{2}{|c}{$\mathrm{IKL}$} \\
\cline { 2 - 4 } & + & + & - \\
\hline \multirow{3}{*}{$\mathrm{RNH}$} & + & $\mathrm{A}$ & $\mathrm{B}$ \\
\cline { 2 - 4 } & - & $\mathrm{C}$ & $\mathrm{D}$ \\
\hline
\end{tabular}

+ bekend met kanker bij het RNH of komt voor in het IKL-bestand; - niet bekend met kanker bij het RNH of komt niet voor in het IKL-bestand.

\section{Fase 3 - nader onderzoek van de discordante groepen (IKL)}

Het IKL controleert de geregistreerde kankerincidenties in groep B (RNH+/IKL-) en groep $\mathrm{C}(\mathrm{RNH}-/ \mathrm{IKL}+)$. Een fout in éen van de componenten van de sleutel kan een verkeerdle koppeling tengevolge hebben; daarom wordt nogmaals een koppeling uitgevoerd, maar nu met een 'deelsleutel': één van de componenten van de oorspronkelijke zoeksleutel wordt weggelaten. De oorspronkelijke componenten van de zoeksleutel waren: geboortedag, geboortemaand, geboortejaar, geslacht en cijfers postcode. Met name kunnen op deze wijze patiënten opgespoord worden waarvan inmiddels de postcode is gewijzigd omdat ze zijn verhuisd.

Gegevens van op deze wijze geidentificeerde patiënten worden nogmaals geverifiëerd

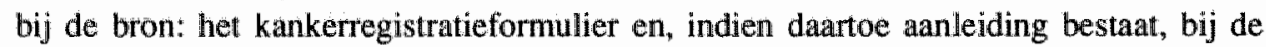
ziekenhuisadministratie. Omdat de effectieve registratie bij het IKL is begonnen op 1-11986 worden alle door het RNH gesignaleerde maligniteiten met een incidentiedatum vór 1986 uit het onderzoekmateriaal van groep $B$ verwijderd.

\section{Fase 4 - verificatie wan de gegevens bij de RNH-praktijken}

Om een maximale bescherming van de privacy te garanderen worden in deze onderzoeksfase gegevens betreffende patiênten in de discordante groepen $B$ en $C$ aangevuld met gegevens van patiënten die 'at random' zijn geselecteerd uit groep D. Dit is het overige deel van de betreffende huisartsgeneeskundige populatie, de patiënten die niet bekend zijn met kanker. Een bijkomend methodologisch voordeel van deze steekproef is een extra controle op eventueel gemiste diagnoses bij zowel RNH als IKL.

Het IKL verstrekt aan het RNH de volgnummers van de patiënten, waarvan de gege- 
Figuur 8.1 Enquêteformulier.

\section{REGISTRATIENET HUISARTSPRAKTIJKBN}

RNH-VOLGNUMMER

PATIENTNUMMER

GEBOORTRDATUM

POSTCODE ( 4 CIJPERS)

GESLACHT

2587
1494
$095 E P 1934$
6713
AMSTERDAN

<- etiket

S.v.P. gegevens zorguildig werifieren an de hand wan patintenaart en cortespondentie vam specialisten.

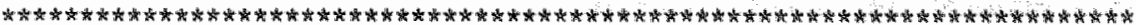

1. Wilt U de gegevens geboortedatum, geslacht en postoode op juistheid controleren. Indien $U$ een fout ontdekt garme corretie:

PATIENTNUMMER $\quad: \ldots \ldots \ldots \ldots \ldots \ldots \ldots \ldots$

GEB.DATUM $\quad: \ldots \ldots \ldots \ldots \ldots \ldots \ldots \ldots$

GESLACHT $\quad: \ldots \ldots \ldots \ldots \ldots \ldots \ldots$

POSTCODF:

2. Is bij deze patient ooit de diagnose kanker gesteld?
o ja
a neen

3. Aantal geciagnostiseerde primaire maligne tumoren *

a een

a meer dan een

(svp voor elke primaire tumor ebr formulier invullen)

4. Indien kanker is gediagnostiseerd:

\begin{tabular}{|c|c|}
\hline $\begin{array}{l}\text { wat is de localisatie } \\
\text { wat is de morfologie }\end{array}$ & 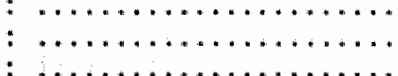 \\
\hline $\begin{array}{l}\text { wat is de diagnosedatum } \\
\text { wat stond vermeld in }\end{array}$ & $=\ldots \ldots \ldots \ldots \ldots \ldots$ \\
\hline
\end{tabular}

5. Is de patient vanmege de diagnose kanker ooit door een specialist gezien en/of behandeld?

o nee, patient is niet doorverwezen

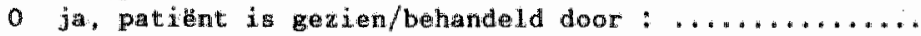

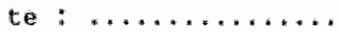

6. De diagmose kanker is bevestigd door:
o histologisch onderzoek
- cytologisch onderzoek
o. róntgenologisch onderzoek
0 anders, te weten :

7. Indien histologisch of cytologische buvestigd :

is dit onderzoek uitgevoerd door

- laboratorium in rabi jgelegen xiekenhui

0 anders, te weten: 
vens nader geverifieerd dienen te worden. Het RNH kan vervolgens de enquêteformulieren voorzien van etiketten met de identificerende informatie van de patiënten (zoals de geboortedatum en de postcode), en de formulieren verzenden naar de betreffende huisartspraktijken (zie fig. 8.1). De huisartsen controleren of de persoonsgegevens juist zijn weergegeven op het etiket en geven aan of betreffende patiënt bekend is met kanker. De huisarts verschaft, indien er sprake is van kanker, aanvullende gegevens betreffende localisatie, morfologie en incidentiedaturn. Dubbeltumoren wordt apart gemeld op bijgeleverde blanco enqueteformulieren. Een tumor die na de peildatum door de huisarts is geregistreerd bij betreffende patiênt wordt alsnog op het enquêteformulier gemeld.

\section{Fase 5 - rangschikking van de resultaten}

$\mathrm{Na}$ rangschikking van de resultaten van de uitgevoerde enquete worden de huisartspraktijken opnieuw benaderd om eventuele onduidelijkheden op de ingevulde formulieren toe te lichten. Wanneer er nog twijfels zijn over de gang van zaken bij de dataoverdracht wordt teruggegaan naar de oorspronkelijke databestanden bij het MEMIC en het IKL.

Omdat beide bestanden nog in een dynamische opbouwfase verkeren worden alle achteraf toch nog geregistreerde tumorgevallen bij het RNH en bij het IKL niet als 'gemiste cases' beschouwd maar in een aparte categorie vermeld. Bij het RNH betreft het hier nieuwe registraties in de periode vanaf de peildatum (1-7-1989) tot het moment waarop de enquête wordt ingevuld (uiterlijk 1-11-1989). Bij het IKL werd ook een periode van 4 maanden na peildatum aangehouden: van 1-10-1989 tot 1-2-1990.

\subsection{Resultaten}

In figuur 8.2 en de tabellen 8.2-8.4 wordt een schematisch overzicht gegeven van de resultaten, zoals die hieronder zijn beschreven.

\section{Fase I - uitgangssituatie bij het 'matchen' van de bestanden}

Bij deze proefstudie moesten we helaas genoegen nemen met een verschil van 3 maanden tussen de peildatum van het RNH en het IKL. Een onverwachte stagnatie in de dataverzameling in de ziekenhuizen was de oorzaak hiervan.

Bij de bestandsvergelijking werd uitgegaan van de volgende uitgangssituatie: RNH

- 9627 patiënten, waarvan 236 patiënten met de diagnose kanker;

- begin van de effectieve registratie: mei/nov 1988;

- peildatum onderzoek: 01-07-1989 (N.B. bij het RNH ook retrospectieve registratie); IKL

- 16132 patiënten, alle met de diagnose kanker;

- begin van de effectieve registratie: 01-01-1986;

- peildatum onderzoek: 01-10-1989.

\section{Fase 2 - indeling van de resultaten in groepen}

De resultaten van de eerste bestandsvergelijking kunnen gerangschikt worden in vier verschillende groepen, zoals reeds eerder werd beschreven (zie 8.2.2). 
Figuur 8.2 De witkomsten.

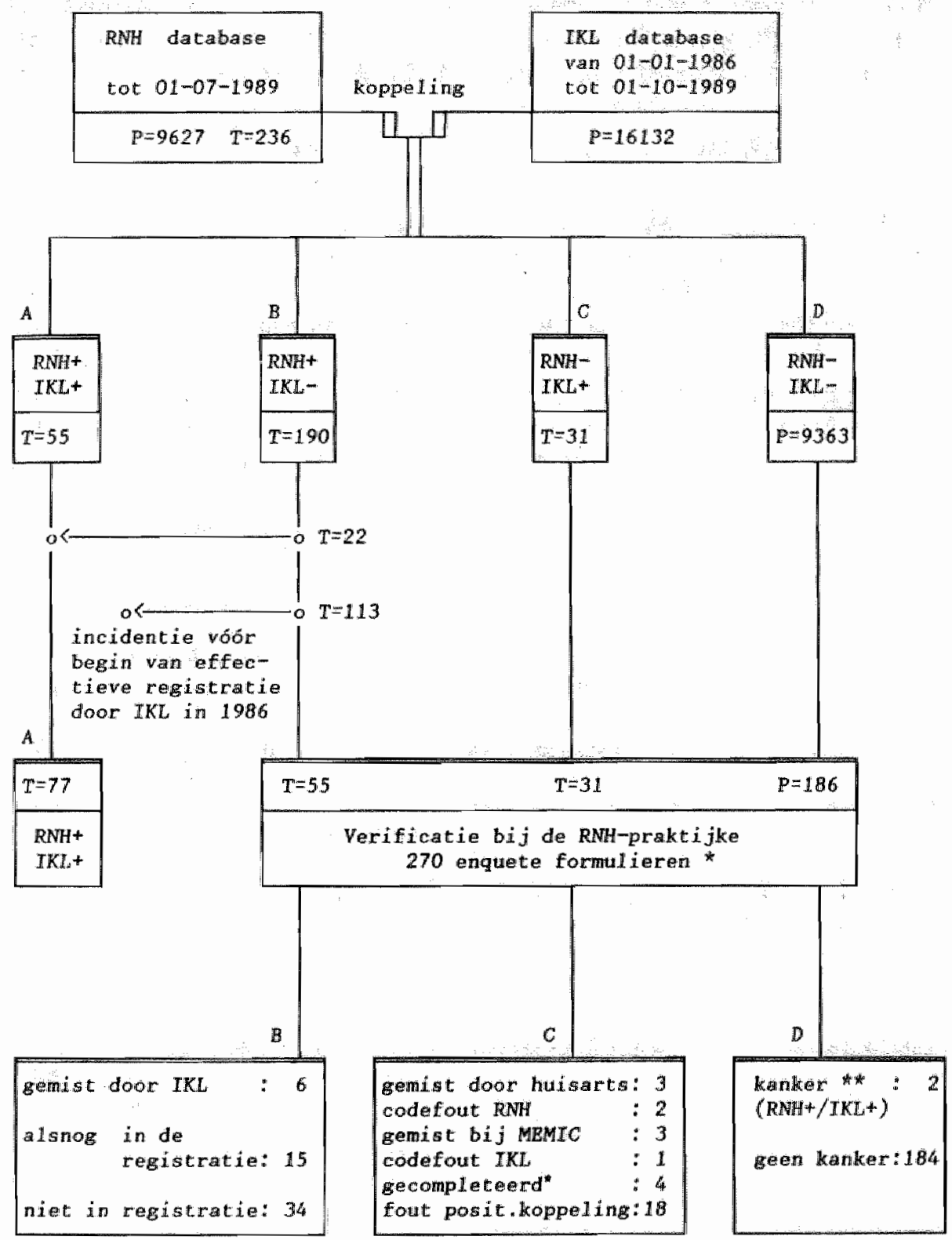

$\mathrm{T}=$ aantal tumorgevallen; $\mathrm{P}=$ aantal patiènten.

* Als cen patiënt met een dubbeltumor geregistreerd was in de groepen B en C, werd slechts een formulier verzonden; dit kwam tweemaal voor.

** Incidentie/registratie na peildatum. 
Indien in dit veslag wordt gesproken over 'tumoren' dan wordt hiermee bedoeld 'primair maligne tumoren', tenzij dit expliciet anders wordt vermeld.

Categorie $D$ bevat de negatieve tumorgevallen, dat wil zeggen: de patienten uit het RNH-bestand die niet bekend zijn met een tumor bij het RNH en ook niet voorkomen in het IKL-bestand. Bij 12 patiènten werd een 'dubbeltumor' ( 2 tumoren) gevonden, derhalwe kan categorie $D$ als volgt worden berekend: $9627(276-12)=9363$

\section{Fase 3 - de discordante bevindingen nader onderzocht (IKL)}

Koppeling met een deelsleutel leverde in groep B 22 patiënten op met enkelvoudige primair maligne tumoren, die bij de eerste bestandskoppeling niet werden opgespoord. Het betrof hier voornamelijk zogenaamde "voorlopige meldingen" bij het IKL, waarbij de identificerende persoonsgegevens nog niet volledig waren ingevuld op het KR-formulier. Deze 22 patiënten met enkelvoudige tumoren werden alsnog ingedeeld bij groep $\mathrm{A}$. In groep B werden voorts 113 tumorincidenties gevonden met een incidentiedlatum vóór 1986. Deze patiëntgegevens werden, omdat van het IKL geen dekking vóór dit tijdstip kan worden verwacht, niet verder betrokken bij het onderzoek: zie groep B1 in tabel 8.3 .

Nader onderzoek door het IKL van de tumorincidenties in groep $C$ leverde geen nieuwe gegevens op. Aldus ontstaat het volgende beeld:

Tabel 8.2 Resulaten van de matching.

\begin{tabular}{|c|c|c|}
\hline & RNH IKL. & $\begin{array}{c}\text { Tumor-gevallen } \\
\qquad n=276\end{array}$ \\
\hline$A$ & $+\quad+$ & 55 \\
\hline B & +- & 190 \\
\hline $\mathrm{C}$ & -+ & 31 \\
\hline D & $-\quad-$ & (P:9363) \\
\hline
\end{tabular}

Toellichting + bekend met kanker bij het RNH of komt voor in het IKL-bestand; - niet bekend met kanker bij het RNH of komt niet woor in het IKL bestand.

P: aantal patiënten die niet bekend zijn met een tumor.

Thabel 8.3 Verdere uitsplitsing van de discordante bevindingen.

\begin{tabular}{lcc} 
& RNH IKL & $\begin{array}{c}\text { Tumor-gevallen } \\
\text { T=276 }\end{array}$ \\
\hline A & ++ & 77 \\
B & +- & 55 \\
B1 & +- & 113 \\
C & -+ & 31 \\
D & - & (P:9363) \\
Toelichting + bekend met kanker bij het RNH of komt voor in het IKL-bestand; - niet bekend \\
met kanker bij het RNH of komt niet voor in het IKL bestand.
\end{tabular}


Fase 4 - resultaten na verificatie by de $\mathrm{RNH}$-praktijen

In totaal zijn 270 enquete-formulieren verzonden naar 9 RNH-praktijken. Nadere informatie werd gevraagd betreffende 55 tumorgewallen uit groep $\mathrm{B}, 31$ tumorgevalien uit groep C (samen zijn dit 84 patiënten, waarvan 2 met een dubbeltumor) en 186 controle patiënten zonder kanker uit groep $\mathrm{D}$.

De respons op deze enquete was $100 \%$ Nadat alle antwoorden waren verwerkt werden

Tabel 8.4 Resultaten ma verificatie bij de RNH-praktijken en na correctie voor de late meldingen bij het IKL.

B RNH $+l \| K L-\quad T=55$

1.1 Niet geregistreerd, echter wel opname en/of PA

1.2 Alleen poliklinisch gezien door specialist zonder PA-bevestiging 1

1.3 Alleen behandeld en gediagnostiseerd door huisarts zelf 0

1.4 Gediagnostiseerd en behandeld buiten de IKL-regio 2

2.1 Inmiddels wel geregistreerd door IKL (na 1-10-1989 en vóór 7-2-1990)

2.2 Verschil in identificatie opgespoord, blijkt alsnog RNH+/AKL+ 2

3.1 Basaalcelcarcinomen (niet geregistreerd door de kankerregistratie)

3.2 Incidentiedatum blijkt na verificatie bij huisarts toch vóor $1986 \quad 8$

3.3 Volgens ICPC maligne, volgens ICD-0 niet maligne

3.4 ICPC-code geldt ook voor benigne neoplasmata, bij verificatie benigne

3.5 Caderingsfout RNH: metastase ten onrechte gecodeerd als primaire tumor

c

RNH - / IKL +

$\mathbf{T}=\mathbf{3 1}$

1. Niet geregistreerd, wel bekend met kanker (gemist bij de huisarts) 3

2. Bekend bij RNH met primair maligne tumor maar fout gecodeerd 2

3. Niet door MEMIC aan het $I K L$ geleverd ondat 1 ICPC-tumorcode abusievelijk niet werd betrokken bij de selectieprocedure

4. Inmiddels wel geregistreerd door huisarts RNH (vóór 1-11-1989) 4

5. Codeerfout bij IKL 1

6. Fout-positieve koppeling bij verificatie

D Controlegroep $\quad P=186$

1. Wel kanker, niet geregistreerd

2. Wel kanker, melding bij $R$ NH en registratie bij huilsarts na 1-7-1989 2

3. Geen kanker 
aarivullende gegevens opgevraagd over 25 patiënten: het ging dan vaak on nadere precisering van de exacte incidentiedatum of de datum waarop de diagnose 'kanker" werkelijk werd gecodeerd. Er werd ook gevraagd naar de exacte diagnose bij ICPC codes die zowel bij maligne turnoren als bij benigne tumoren worden gebruikt, zoals F74 en L71 (bijlage 8.I). Ook werd aanvullende informatie verkregen over de exacte stagering bij sommige tumoren wanneer dit van belang was, zoals bijvoorbeeld bij blaaspapillomen $(0=$ geen maligniteit). Vervolgens werden de resultaten gerangschikt in tabel 8.4

\subsection{Beschouwing en conclusies}

\section{De onderzoekprocedure}

Het was mogelijk om het voorgestelde onderzoek op efficiënte wijze uit te voeren. Beide bestanden bleken voldoende toegankelijk voor onderzoek en konden met behulp van de toegepaste 'matching procedure' goed met elkaar vergeleken worden. Ook de verificatie van de resultaten van de uitgevoerde bestandskoppeling bij de originele signaleringsbronnen, die als 'referentie-bestand' fungeerden, verliep probleemloos. De enquête bij de huisartsen, aangevuld met incidentele directe mondelinge toelichting, leverde de benodigde informatie op. De respons op deze enquête bij de huisartsen was maximaal, de extra werkbelasting was niet groot. Fouten in registratie, dataoverdracht en dataselectie konden getraceerd en gelocaliseerd worden.

Ook het IKL kon alle gegevens die daarvoor in aanmerking kwamen effectief bij de bron controleren op volledigheid en betrouwbaarheid.

\section{De steekproef (groep D)}

In de steekproef, groep D, werden bij de enquête toch nog 2 tumoren opgespoord: één pancreascarcinoom en én basalioom. Beide tumoren hadden een geverifieerde incidentiedatum na de peildatum. Bij de 186 personen van de steekproef mogen op basis van de geslachts- en leeftijdsspecifieke incidentiecijfers van het IKL per jaar 0,77 nieuwe maligniteiten verwacht worden. Na de RNH-peildatum zijn 4 maanden verlopen tot verificatie en kunnen dus $4 / 12 \times 0.77=0.26$ nieuwe maligniteiten verwacht worden. Dat er door het IKL eén maligniteit gevonden wordt in de steekproef (pancreascarcinoom) is dus niet onwaarschijnlijk.

Bij de enquête werden in de steekproef geen tumoren gevonden met een incidentiedatum vór de peildatum (1-7-89). Het door het RNH ook nog opgespoorde basalioom is wel degelijk een nieuw opgetreden tumor.

\section{Teller en noemer}

Bij de opzet van dit onderzoek is rekening gehouden met het gegeven, dat het RNH-bestand en het IKL-bestand nog in een dynamische opbouwfase verkeren en een beperkte omvang hebben. Wanneer men de resultaten toch in cijfers wil vangen, dan zal dit onder enig voorbehoud moeten gebeuren.

Dit geldt met name voor het IKL-bestand omdat hierin slechts de gegevens vanaf 1-11986 zo volledig mogelijk zijn opgeslagen. Voordat een getalsmatige schatting van de 
Bijlage 8.1 Maligne neoplasmata volgens de Mnervational Classification of Primary Care (ICPC, Nederlandse vertaling "Short hitles" jamari 1989).

\begin{tabular}{|c|c|c|}
\hline & A79 & Maligne neopl. (onbekende primlok) \\
\hline & B72 & Hodgkin / andere maligne lymfomen \\
\hline & $\mathrm{B} 73$ & Leukaemie \\
\hline & B74 & Andere mallneopl. bloed/bloedv.org. \\
\hline & D74 & Maligne neoplasma maag \\
\hline & D75 & Maligne neoplasma colon/ rectum \\
\hline & D76 & Maligne neoplasma pancreas \\
\hline & D77 & ne neopl.tr..dig.and./niet gespe \\
\hline & D78 & \\
\hline & $\mathrm{F} 74$ & lasma oog/adnexen \\
\hline & $H 75$ & Neoplasmata oor \\
\hline & $\mathrm{K} 72$ & Neoplasma tr.circulatorius \\
\hline & L71 & $\mathrm{Ne}$ \\
\hline & N74 & Mali \\
\hline & N76 & zenwstelsel \\
\hline & R84 & Maligne neop \\
\hline & R85 & asmata tr.resp. \\
\hline & S77 & Maligne neoplasma huis/subcutis \\
\hline & S80 & /subcutis \\
\hline & T71 & Mali \\
\hline & T73 & pl.endo.kl. \\
\hline & U75 & $\mathrm{M}$ \\
\hline & U76 & Maligne neoplasma blaas \\
\hline & UT7 & Andere maligne neopl.urinewegen \\
\hline & UT: & \\
\hline & W72 & Mali \\
\hline & $\times 75$ & erv"x $\times$ uteri \\
\hline & $\times 76$ & Maligne neopliborsten (vrouw) \\
\hline & $\times 77$ & And.maligne neopl.gesl.org. (vrouw). \\
\hline & $\times 81$ & And./niet gespec.neopl.gesl.org. \\
\hline & Y77 & Ma \\
\hline & $\vee 79$ & And.mal.neopl.gesl.org./borst.(m \\
\hline
\end{tabular}

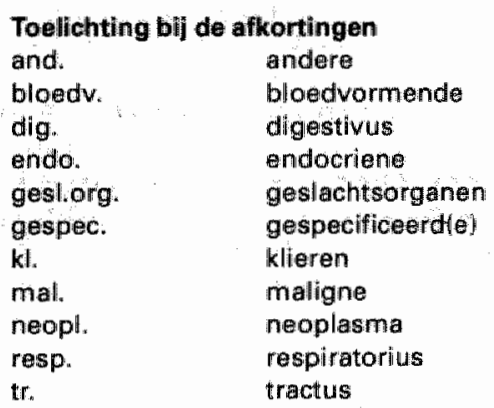


volledigheid en de betrouwbaarheid van beide databanken kan gegeven worden zal eerst een noemer bepalild moeten worden: hel aantal primair maligne tumoren dat minstens in Gen van beide registraties werd gevonden. Dit getal kan als volgt berekend worden uit de onderzoekresultaten die zijn weergegeven in tabel 8.4 en figuur 8.2 :

$\begin{array}{lr}\text { Groep A } & : 77 \\ \text { Groep B1.1 B1.4 } & : 5 \\ \text { Groep B2.1 B2.2 } & : 15 \\ \text { Groep C1 C4 } & : 12 \\ = & 109\end{array}$

Bijlage 8.2 Gemiste registraties.

\section{Gemist door de RNH-artsen}

1. Man met een geregistreerd oesofaguscarcinoom. Tevens bij het IKL bekend met een prostaatcarcinoom, dat niet werd geregistreerd door de huisarts.

2. Vrouw met een maligne melanoom van de vulva als toevalsbevinding bij onderzoek door de gynaecoloog. Deze diagnose werd "tussen de regels door' vermeld in de ontslagbrief en daarom door de huisarts gemist.

3. Mammacarcinoom dat duidelijk stond vermeld in het "journaal", maar door de huisarts werd vergeten in de probleemlijst.

4. Man met plaveiselcelcarcinoom van de bovenste luchtwegen, de huisarts vermeldde dit in de probleemlijst maar codeerde abusievelijk met R86 in plaats van R85.

5. Mammatumor, aanvankelijk correct gecodeerd als $\times 19$ (knobbel/zwelling borsten), later niet op tijd gereviseerd (naar $X 76$ ) toen duidelijk werd dat dit een mammacarcinoom was.

\section{Gemist door het IKL}

1. Man van hogere leeftijd met prostaatcarcinoom. In het buitenland gediagnostiseerd en behandeld.

2. Kind met nefroblastoom, behandeld in gespecialiseerde kliniek in Nederland.

NB zal in de toekomst door andere regionale kankerregistratie worden geregistreerd.

3. Man van hogere leeftijd met longcarcinoom. Alleen poliklinisch bekend, er is geen PA-bevestiging. Zal alleen door de Regionale Kaṇkerregistratie geregistreerd worden als andere signaleringsbronnen worden gebruikt (röntgenoloog, POLIS-registratie).

4. Kind met leukemie opgenomen in ziekenhuis in de IKL-regio.

5. Vrouw met cystosarcoma phylloides van de mamma. Waarschijnlijk gemist door IKL omdat PALGA deze tumor niet signaleert aan de kankerregistratie als de patholoog niet 'maligne' aan deze diagnose toevoegt. (Is in 1989 door PALGA aangepast, zodat al deze tumoren worden gesignaleerd ten behoeve van de kankerregistratie).

6. Man van middelbare leeftijd met $M$. Bowen van de huid. PA-bevestiging en behandeling in de IKL-regio. 


\section{De volledigheid van de kankerregistratie}

Hoewel beide bestanden nog in een dynamische opbouwfase verkeren kan men toch een schatting maken van het aantal 'gemiste' primair maligne tumoren en to een uitspraak doen over de volledigheid van beide onderzochte registraties.

Bij het RNH werden 8 tumoren gemist. Herbij dient opgemerkt te worden, dat 3 van deze tumoren wel correct door de huisarts waren geregistreerd en waren vastgelegd in de databank bij het MEMIC. Het betreft hier een technische fout bij de dataoverdracht, een ICPC-tumoncode werd overgeslagen bij het rubriceren en selecteren wan de gegevens uit dit centrale bestand en werd door het IKL dus ook niet aangetroffen op de aangeleverde diskette. Deze 3 cases zijn dus geen echte 'missers' en zo komen we op 5 gemiste cases (4.5\%) op 109 primair maligne tumoren.

De registratie bij het IKL komt met $5,5 \%$ gemiste registraties vrijwel op een zelfde getal uit, zodat we kunnen stellen, onder het eerder genoemde voorbehoud, dat beide registraties $95 \%$ volledig zijn.

Het uitgevoerde onderzoek maakt ook aannemelijk dat beide registraties elkaar kunnen aanvullen: het $\mathrm{RNH}$ kan de 'blinde vlekken' bij het IKL zichtbaar maken en vice versa.

\section{De betrouwbaarheid van de kankerregistratie}

Het gevonden aantal niet correcte registraties geeft een indruk van de betrouwbaarheid van de gegevens die zijn vastgelegd in de databanken van $\mathrm{RNH}$ en $\mathrm{KKL}$ (tabel 8.4).

Bij het RNH werden 8 onjuiste registraties gevonden:

- B3.5 codeerfout: metastase ten onrechte gecodeerd als primaire tumor (fout positief):

3 maal;

- C1.1 niet geregistreerd door huisarts maar wel met kanker bekend (fout-negatief):

3 maal;

- C2 bekend met primair maligne tumor maar verkeerd gecodeerd (fout-negatief):

2 maal.

Bij het IKL werd 1 onjuiste registratie gevonden: C5 foutieve codering, ten onrechte opgenomen in het IKL-bestand.

De betrouwbararheid van de door het IKL vastgelegde gegevens was hoog, zoals valt te verwachten bij een specifieke registratie. De betrouwbarheid van de door het RNH vastgelegde gegevens was voldoende bij deze proefstudie.

\section{Eindconclusie}

Tot slot mag gesteld worden dat een vergelijkend onderzoek van twee databestanden, zoals in dit hoofdstuk werd beschreven, een goed instrument is om de gegevens die vastgelegd zijn in beide registratiesystemen te toetsen op betrouwbaarheid en volledigheid. Opgemerkt moet worden dat er een aantal methodologische knelpunten naar voren zijn gekomen, die speciale aandacht verdienen bij een eventuele herhaling van dit onderzoek. Met name lijkt het belangrijk om meer aandacht te besteden aan het synchroniseren van de peildatum, aan het systematisch registreren van dubbeltumoren in alle fasen van het onderzoek, aan het zorgvuldig bepalen van de verschillende "noemers" en het bepalen van de omvang van het steekproefbestand.

De ervaring die we hebben opgedaan vormt een goedle basis voor een vervolgonderzoek, wanneer beide databestanden hun definitieve vorm hebben gevonden. 


\section{Literatuur}

1. Berkel I. Volledigheid van de kankerregistratie. Ned Tijdschr Geneeskd 1989;133,nr 41 .

2. Benraad J,Leewwen FE van. Kankerregistratie en Epidemiologie. TMI 1988;17:7-11.

3 Hoelen AJ. K waliteit en doelmatigheid van de medische databases; kwaliteitszorg in de landelijke gezondheidszorg. TMI 1986:15:14-16.

4. Ministerie van Welzijn Volksgezondheid en Cultuur. NOTA 2000 ; over de ontwikkeling Yan het gezondheidsbeleid. Rijswijk Ministerie van WVC; 1986.

5 Schadé E, ljzermans CJ. Over de volledigheid van de voorgestelde landelijke kankerregistratie. Huisarts Wet 1985,28:171-3.

6 Berkel J. Huisarts en karkenegistratie. Huisarts Wer 1985,28:171-3.

7 Vecht-Hart CM, Noord PAM van. Kankerregistratie gepeild: karkerregistratie in de eerstelijns gezondheidszorg. Utrecht: Nederlands Instituut voor onderzoek van de eerstelijns gezondheidszorg (NIVEL).

8 Sehouten LJ Brandt PA van den, Jager JJ. Regionalle kankerregistratie IKL. Kankerincidentie 1986. Maastricht, Integraal Kankerinstituut (IKL), 1989.

9 Jaarverslag 1988. Maastricht, Integraal Kankerinstituut (IKL), 1989.

10 Schouten LJ, Brandt PA van den, et al. Ontwikkeling van een protocol ten behoeve van de koppeling met de kankerregistratie. TSG, 1989,4 (middenkatem): 19.

11 Brandr PA van der, Schouten LJ, Goldbohm RA, et al. Development of a record linkage protocol for use of the Dutch cancer registry for epidemiological research Int J Epidemiol 1990, in press. 


\section{De personal computer en de kwaliteit van de arts-patiënt relatie}

Tien maanden na de installatie van een computer in de spreekkamer van een huisartspraktijk is aan 390 patienten een (van te voren uitgetest) survey-yragenformulier toegestuurd. Het oorded van de patiënten over de relatie met hun hwisarts na invoering van de computer werd vergeleken met hun oordeel over de relatie voordat de huisarts net een computer werkte. Meer dan $96 \%$ van de patienten $(n=263)$ verklaarde dat het contact met hun dokter even gemakkelijk en persoonlijk was als eerst. De meeste patienten waren van mening dat de computer geen invloed had op de duur van het consult. Daar staat tegenover dat 81 patiènten ( $30 \%$ ) dachten dat hun privacy was verminderd. In tegenstelling tot opinie-onderzoeken onder patiënten die nog geen concrete ervaringen hadden met computergebruik door de huisarts, heeft de onderhavige studie uitgewezen dat patienten weinig moeite hebben met de aanwezigheid van een computer in de spreekkamer. Desalniettemin moeten artsen hun patiënten informeren over eventuele verbindingen tussen hun computer en andere, exter"ne computers om de angst voor aantasting van de privacy weg te nemen.

\subsection{Inleiding}

Hoewel computers tot bijna alle geledingen van de maatschappij zijn doorgedrongen en inmiddels voor de meeste mensen een wertrouwde aanblik vormen, worden ze nog niet op grote schaal gebruikt in de spreekkamers van huisartsen. Cruickshank heeft bij twee groepen patiënten de mening gepeild over het gebruik van computers in de huisartsenpraktijk.

De eerste groep had ooit te maken gehad met een computer in de spreekkamer, de tweede groep niet. In allebei de groepen geloofde meer dan de helft van de patiënten dat het gebruik van een computer ten koste zou gaan wan het persoonlijke contact met de arts.

Pringle en medewerkers hebben, alvorens een computer te installeren in de spreekkamer, onderzocht hoe hun patienten stonden tegenover de aanwezigheid wan een personal computer. ${ }^{2}$ De onderzoekers rapporteerden dat $31 \%$ van de patienten bang was dat de vertrouwelijkheid van hun gegevens in het gedrang zou komen. Bij deze onderzoeken ging het echter om patiènten die geen ervaring hadden met computergebruik door hun eigen huisarts. In de onderhavige studie is onderzocht hoe patiënten oordelen over de contacten met hun huisarts als een computer aanwezig is in de spreekkamer.

De patiënten die tijdens de contacten met hun huisarts vanaf augustus 1986 gedurende

Dir hoofdstuk werd eerder gepubliceerd als: Rethans JJ, Höppener P, Wolfs G, Diederiks J. Do personal computers make doctors less personal? Br Med J 1988; 296: 1445-8. Een Nederlandse vertaling ver. scheen in Medisch Contact: Rethans. $\mathbb{J}$. Höppener $P$, Wolfs $G$, Diederiks J. Verslag van een onderzoek naar de mening van patiënten. Maakt een personal computer het contact met de arts minder persoonlijk? Med Contact 1989; 44:237-40. 
een periode van tien maanden met de computer waren geconfrorteerd, kregen een vragenlijst thuiggestururd. Het onderzoek was bedoeld on de mening van patienten over het spreekkamercontact met hur eigen huisarts vór en na de installatie van een computer te vergelijken.

\subsection{Patiênten en methoden}

On een gestructureerde vragenlijst te kunnen ontwikkelen werden zes patiënten geïnterviewd door een onderzoekassistent die de patienten niet kende. De selectie van deze patiènten werd overgelaten aan de praktijkassistente. De zes patiënten waren representatief voor verschillende leeftijdsgroepen en waren bereid om te praten over de contacten met hun huisarts. De bandopnamen van deze interviews werden uitgetikt en uit de transcripten werden items geselecteerd voor de gestructureerde vragenlijst. Deze hadden betrekking op het persoonlijk contact, de privacy en de invloed op de duur van het consult. Op basis van deze items werden 16 stellingen geformuleerd ( 7 in positieve en 9 in negatieve bewoordingen) die vervolgens willekeurig werden gerangschikt. De patiënten werd gevraagd in te vullen of zij het "volledig oneens", "gedeeltelijk oneens", "gedeeltelijk eens" dan wel "volledig eens" waren met de stellingen. De vragenlijst werkte zo volgens een "vierpunts-schaal' ${ }^{3}$ De vragenlijst werd uitgetest onder patiënten die het spreekuur van hun huisarts bezochten. Als ze de vragenlijst hadden ingevuld werd aan de patienten gevraagd of zij de stellingen duidelijk en ondubbelzinnig vonden. De opmerkingen van de patiènten hielpen on bij het opstellen van de uiteindelijke versie.

Aangezien we geinteresseerd waren in de mening van die patiënten die zowel vóór als na de installatie van de computer contact hadden met hun huisarts, selecteerden we alleen patiënten die:

a. hun huisarts hadden geraadpleegd binnen een periode van tenminste een jaar vór invoering van de computer;

b. hun huisarts minstens énmaal hadden geraadpleegd na invoering van de computer en c. ouder waren dan 12 jaar.

De patiènten werden geselecteerd uit een lijst van alle patiënten die de praktijk tussen 27 maart 1987 en 20 mei 1987 (mer uitzondering van de twee weken waarin de dokter met vacantic was) op een maandag-,woensdag- of vrijdagochtend bezochten. Op deze wijze werden 390 patienten geselecteerd die voldeden aan onze insluitingscriteria. Omdat patiënten ertoe neigen antwoorden te geven die gunstig uitvallen voor hun huisartsen, ${ }^{4}$ hebben wij de Universiteit van Limburg gemachtigd de vragenlijst aan de patiënten te versturen en de antwoorden in ontvangst te nemen. In een begeleidend schrijven werd de nadruk gelegd op de volstrekte anonimiteit van de patienten vanwege de evidente noodzaak om bij dit soort informatie de anonimiteit te watarborgen en om het aantal niet-respondenten, dat op grond van andere onderzoeken hoog werd geschat ${ }^{12}$ zo laag mogelijk te houden.

In de onderzochte praktijk werd sinds augustus 1986 gewerkt met een personal computersysteem, bestaande uit een computer en twee terminals. Het hele spreekuurproces werd geautomatiseerd en de artsen toetsen alle informatie die zij van de patiënten kregen 
rechtstreeks in. Bijgevolg werden niet alleen administratieve gegevens geregistreerd (deze werden alleen bij het eerste bezoek in de computer ingevoerd), maar werd het gehele klinische proces (klinische notities) vastgelegd. De praktik telde 2900 patienten die tijdens het ochtendspreekuur door twee artsen en 's middags door eén arts werden geholpen, bijgestaan door twee half-time doktersassistentes. De praktijk bevond zich in Heerlen, een stad met in totaal zo'n 94.000 inwoners.

\subsection{Resultaten}

Van de 390 verstuurde vragenlijsten werden er $270(69,2 \%)$ geretourneerd. Zeven daarvan waren niet bruikbaar voor het onderzoek: vier omdat de respondenten niet wilden meewerken aan een onderzoekproject en drie omdat de respondenten verklaarden dait ze hun huisarts en de computer te weinig hadden gezien. De 263 resterende vragenlijsten vertegenwoordigden $67,4 \%$ van het totale aantal verstuurde formulieren. Voor deze 263

Tabel 9.1 Responsen op de stellingen in de vragenlijst. De cijfers hebben betrekking op het aantal (percentage) patiënten $(n=263$ ).

\begin{tabular}{|c|c|c|c|c|c|}
\hline \multicolumn{2}{|c|}{ Item n. } & \multirow{2}{*}{$\begin{array}{l}\text { Wollodig } \\
\text { ondeens } \\
3(1,1)\end{array}$} & \multirow{2}{*}{$\begin{array}{r}\begin{array}{c}\text { Gediealtetijk } \\
\text { oneens }\end{array} \\
7(2,7)\end{array}$} & \multirow{2}{*}{$\begin{array}{c}\begin{array}{c}\text { Gedeeltelijk } \\
\text { enens: }\end{array} \\
66(32,7)\end{array}$} & \multirow{2}{*}{$\begin{array}{l}\begin{array}{c}\text { Volled } \\
\text { conts }\end{array} \\
167[63,5)\end{array}$} \\
\hline 1. & $\begin{array}{l}\text { Nu lij een computer gebruikt kan ik net zo gemekkelijk met } \\
\text { mijin huisarts praten als eerst }\end{array}$ & & & & \\
\hline 2. & Het consult duturt langer nu miln huistarts een computer gebrulkt & $54(20,5)$ & $174(66,2)$ & $20(7,6)$ & $15(5.7)$ \\
\hline 3 & $\begin{array}{l}\text { Fatienten die prijs stellen op een goed persoonlijk contact } \\
\text { me: hun dokter moeten een huisants zonder computer kiezen }\end{array}$ & $114(43,3)$ & $124(47,1)$ & $10(3,8)$ & $15(5,7)$ \\
\hline 4. & $\begin{array}{l}\text { De wachittid voor het consult is korter gewortien sints } \\
\text { mijn huisarts ien computer gebruikt }\end{array}$ & $31(11,8)$ & $165(62,7)$ & $49(18,6)$ & $18(6,8)$ \\
\hline 5 & $\begin{array}{l}\text { Hot hob gemerkt dat miln hulsarts miln madische gegevens } \\
\text { sinds thill wen computer heeft snetter kan overzien }\end{array}$ & $5(1,9)$ & $30(11,4)$ & $99(37,6)$ & $129(49 ; 0)$ \\
\hline 6. & $\begin{array}{l}\text { Sinds de introductie van de computer in de praktijk is het } \\
\text { contact met milim huisiarts iminder persoonlijk gevtorden }\end{array}$ & $119(42,5)$ & $125(47,5)$ & $12(4,6)$ & $7(2,7)$ \\
\hline 7 . & Het idee van wen dokler met een computer staet mit tegen & $151(\$ 7,4)$ & $94(35,7)$ & $1.4(5,3)$ & $4(1,5)$ \\
\hline c. & 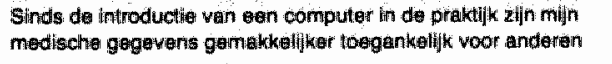 & $64(24,9)$ & $118(44,9)$ & $01(23,2)$ & $20(7,0)$ \\
\hline 9 & 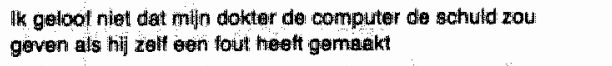 & $36(13,7)$ & $70(26,6)$ & $107(40.7)$ & $50(18,0)$ \\
\hline 10. & $\begin{array}{l}\text { Sinds hif oen compuner gebruikt besteredt miln huisarts } \\
\text { tijderis hel consult moer tijd aan mij }\end{array}$ & $26(9,8)$ & $174(66 ; 2)$ & $49(16,3)$ & $10(5,7)$ \\
\hline 11. & $\begin{array}{l}\text { Sinds miln huisarts ean computer gebruikt voed } 1 \mathrm{k} \text { mil meer } \\
\text { dan berst alleen oen nummet }\end{array}$ & $427(48,3)$ & $126(4 \pi, 9)$ & $7(2,7)$ & $3(1,4)$ \\
\hline 12 & $\begin{array}{l}\text { Computers maken te verel fouten om miln medische } \\
\text { gegeverns alam zes toe to vertitrouwien }\end{array}$ & $95(36,1)$ & $156(59,3)$ & $B(3,0)$ & $4(1 ; 6)$ \\
\hline 13. & $\begin{array}{l}\text { Met oen computer behandalt mijn huistarts mij betar dans } \\
\text { toen hil nog goen computer had }\end{array}$ & $52(19,8)$ & $171(66,5)$ & $29(11,0)$ & $14(4,2)$ \\
\hline 14. & $\begin{array}{l}\text { Met min medische gegevens in de computer is mijn privacy } \\
\text { beter gewwarborgd }\end{array}$ & $29(11.0)$ & $146(55,5)$ & $70(26,16)$ & $\| \in(6,8)$ \\
\hline 15. & 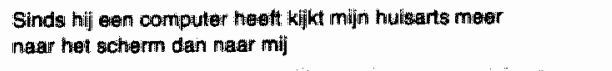 & $95(36,1)$ & $143(54,5)$ & $18(6,8)$ & $7(2,7)$ \\
\hline 16. & $\begin{array}{l}\text { Artsen die om hun pattelinten geven installeren geen computer } \\
\text { in hun praktijk }\end{array}$ & $139(152,5)$ & $114(43,4)$ & $6(2,3)$ & $5(1,8)$ \\
\hline
\end{tabular}


Tabel 9.2 Arantal spreckurcowocter wa installatie wan de computer.

\begin{tabular}{lr}
\hline Aantal contacten & $\left.\begin{array}{c}\text { Aantal ipercentag } \\
\text { patiềnten }(\mathrm{n}=26\end{array}\right)$ \\
\hline $1-2$ & $86(32,6)$ \\
$3-4$ & $10.4(39,5)$ \\
$5-6$ & $55(20,9)$ \\
$7-10$ & $9(3,4)$ \\
$\geq 11$ & $9(3,4)$
\end{tabular}

vragenlijsten bedroeg Crombachs $\alpha$, een mat voor de interne consistentie, 0,76. Tabel 9.1 geeft een overzicht van de responsen op de 16 uitspraken in de vragenlijst. De gemiddelde leeftijd van de respondenten was 45 jaar (variatiebreedte 12-87; SD 18), wat niet significant verschilde van de leeftijd wan de niet-respondenten. Tabel 9.2 toont het aantal spreekkamercontacten dat de patienten na installatie van de computer met hun huisarts hadden. Drieendertig patienten hadden thuis zelf een personal computer en 181 patiënten gebruikten een personal computer op hun werk. Praktisch alle patiënten (item 1: 92,2\%) verklaarden dat het contact met hun huisarts net zo gemakkelijk was als eerst en ook niet minder persoonlijk was geworden (item 6:92,7\%). Over het algemeen waren de patienten het niet eens met de stelling dat patiènten die prijs stellen op een goed persoonlijk contact met hun dokter een huisarts zonder computer moeten kiezen (item 3: 90,1\%). Ook waren zij het niet eens met de uitspraak dat de artsen die om hum patiënten geven geen computer zouden moeten installeren (item 16:95,9\%)

De meeste patiënten stelden vast dlat het consult niet langer duurde dan voorheen, vóór de installatie van de computer (item $2: 86,7 \%$ ), dat de huisarts niet meer tijd aan hen besteedde (item 10:76,1\%) en dat ze niet sneller aan de beurt waren voor een consult (item 4: $74,5 \%)$.

Met betrekking tot de privacy dacht een minderheid dat hun persoonlijke gegevens nu gemakkelijker toegankelijk waren voor anderen (itern $8: 30,8 \%$ ) en de meeste patiënten waren het niet eens met de uitspraak dat hun privacy nu beter was gewaarborgd dan vóór de invoering van de computer (item 14:66,5\%). De patiènten leken te denken dat hun huisarts met de computer sneller een beeld had van hun medische geschiedenis (item 5 : $86,6 \%$ eens), matr vonden niet dat hun huisarts hen nu beter behandelde (item $13: 84,8 \%$ oneens)

Er is geen significante conrelatie gevonden tussen het aantal spreekkamercontacten, de leeftijd en de opleiding van de patiênten en hun gemiddelde score op de vragenlijst.

\subsection{Beschouwing}

Pringle heeft gerapporteend dat $31 \%$ van de patiënten geloofde dat het invoeren wan een computer ten koste zou gaan van het persoonlijke contact met de huisarts. ${ }^{2}$ Cruickshank rapporteerde een nog hoger cijfer: ${ }^{\prime}$ in haar onderzoek dacht meer dan de helft van de pa- 
tiënten er zo over. Een van de belangrijkste factoren die een rol spelen in de huisartsenpraktijk is het geloof of het wertrouwen dat patienten in hun dokter hebben.

Bass en medewerkers hebben onderzoek gedaan naar de afloop van werschillende ziektes die veel voorkomen in de huisartsenpraktijk. $\mathrm{Zij}_{\mathrm{k}}$ wamen tot de conclusie dat de afloop in de eerste plaats werd beinvloed door de mate van overeenstemming over de ziekte tussen de patiënt en de huisarts en in de tweede plats door het vertrouwen in hun relatie.

In de onderzoeken van Pringle en Cruickshank ging het om patiênten die nog geen ervaring hadden met computergebruik door hun huisarts.

Bij de patiènten in het onderhavige onderzoek was dat wel het geval. Het lijkt erop dat consulten waarbij de huisarts gebruik maakt van een computer de patiënten van mening doen veranderen. Uit de responsen op de items $1,3,6,11$ en 16 mag worden afgeleid dat de computers niet veel verandering brengen in het persoonlijke contact tussen de patiènt en de huisarts. De aanvullende opmerkingen die 46 (18\%) van de 262 patiènten in antwoord op de wragenlijst neerschreven, lijken dit te bevestigen. Van deze 46 patiënten maakten 17 (37\%) opmerkingen als: "er is niets veranderd met de computer; mijn huisants is goed' en 'het maakt mij niet uit of er een conputer in de spreekkamer is". Zeven patiënten $(15 \%)$ verklaarden duidelijk te merken dat de huisarts hun medische gegevens sneller kon overzien met de computer. Drie patiènten (6\%) waren van mening dat het contact met hun huisarts juist persoonlijker was geworden, omdat zij konden lezen wat de dokter intoetste. Tenslotte waren er nog drie patiënten (6\%) die opmerkten dat zij de relatie met hun huisarts gelijkwaardiger vonden dan eerst. De computer leek geen invloed te hebben op de duur van de consulten (items 2,4 en 10)

Zoals gezegd hebben we geen belangrijke correlaties gevonden tussen leeftijd, atantal. consulten en opleiding en de totale score op deze vragenli.jst. In dit opzicht werschillen onze resultaten van die van Cruickshank.' Wij schrijven dit toe aan het verschil in ervaring met de computer in de spreekkamer tussen haar patiënten en onze patiënten. Wan neer alle patiënten enige tijd ervaring hebben met de computer leveren de hierboven genoemde variabelen geen verschillen meer op tussen de patiënten.

Nogall verontrustend is de bevinding dat $66 \%$ van de patiënten het niet eens was met de stelling dat hun privacy met de computer beter gewararborgd was (item 14). Daarentegen was $69 \%$ van de patiënten het niet eens met de stelling dat de medische gegevens sinds de introductie van de computer gemakkelijk toegankelijk waren voor anderen (item 8). Patienten lijken dus ambivalente gevoelens te hebben ten aanzien van dit aspect. Het kan zijn dat het woord "privacy" voor de meeste mensen te zwar beladen is. De afgelopen jaren is het woord (meestal in negatjeve context) gebruikt in praktisch elke discussie over computers en het heel goed mogelijk dat dit heeft geleid tot een vertekend beeld bij de patiënten. Dit zou een verklaring kunnen vormen voor de schijnbaar tegenstrijdige responsen op de items 8 en 14. Item 8 verwijst nalar een situatie die vertrotuwder is voor de patiënten en gemakkelijker is te begrijpen. Als gevolg van de reacties op de stellingen 8 en 14 zijn wij onze patiënten gaan informeren over het feit dat onze computer op geen enkele manier is verbonden met een computer of telefoonlijin buiten de praklijk.

In hoeverre zijn onze bevindingen beinvloed door de niet-respondenten? Toen het onderzoek van start ging hadden wij - gezien de ervaringen van eerdere onderzoekers ${ }^{12}$ het idee dat een groot deel van de patiënten niet bereid zou zijn hun mening te geven op 
de vragenlijst. Bij de door ons gevolgde procedure waren de patiënten volstrekt anoniem. Om die reden was het onmogelijk de niet-respondenten op te sporen. Wij zien de $30 \%$ niet-responidenten niet als een erg grote groep. Voor wat betreft de leeftijd verschilden zij niet systematisch wan de patienten die wel reageerden. We hebben ook gekeken naar het aantal patiënten dat de praktijk verliet na de installatie van de computer. Vergelijking met dezelfde periode in het voorgaande jaar leverde geen verschil op. Wij neigen dan ook tot de conclusie dat de niet-respondenten niet wezenlijk van invloed zijn geweest op de hier gepresenteerde resultaten. Een andere factor die de resultaten mogelijk heeft beinvloed is het feit dat het onderzoek zich beperkte tot én praktijk. Voor zover ons bekend waren wij echter de eersten in Nederland die op de hierboven beschreven wijze gebruik zijn gaan maken van een computer in de praktijk en wij waren niet in staat het onderzoek uit te breiden tot een vergelijkbare huisartsenpraktijk elders in Europa.

De voornaarnste conclusie van dit onderzoek is dat patiênten weinig moeite hebben met de aanwezigheid van een computer in de spreekkamer. Een andere belangrijke conclusie is dat personal computers het contact met de arts niet minder persoonlijk maken. Het is nog altijd de persoonlijkheid van de arts die uitmaakt of hij (zij) in de contacten met patiënten meer of minder persoonlijk is. De computer is maar een hulpmiddel. Om de angst voor aantasting van de privacy weg te nemen zouden artsen die een computer in hun praktijk willen installeren er goed aan doen hun patiënten duidelijk te informeren over eventuele verbindingen met andere computers.

\section{Literatuur}

1. Cruickshank PJ. Computers in medicine: patients' attitudes. J R Coll Gen Pract 1984; 34:77-80.

2 Pringle M. Robins S. Brown G. The patient's view. Br Med J 1984; 288:289-92.

3 Oppenheim AN. Questionnaire design and attitude measurement. London: Heinemann, 1966.

4 Woolley FR. Kane RL. Hughes CC. et al. The effects of doctor- patient communication on satisfaction and outcome of care. Soc Sci Med 1978; 12:123-8.

5 Bass MJ, Buck C, Rurner L, et al. The physician's actions and the outcome of illness in family practise. J Fam Pract 1986; 23:43-7. 


\section{De bereikbaarheid van de 'groene kaart' bij waarneming}

De automatisering maakt een optimale bereikbaarheid van patièntendossiers tijgens vacantiewatrnemingen mogelijk. Een ware uitkomst voor de huisarts dus. Een uitkomst in alle opeichten? Hoe denken de patiënten er zelf over? Dit hoofdstuk beschrijft een veldtest in 3 Zuidlimburgse huisart spraktijken, waar de solistisch werkende huisartsen beurtelings tijdens elkaars vacantie inzage kregen in de geautomatiseerde patièntendossiers van de afwezige collega's. De mening van de patiënten hierover werd getest wia een anonieme oriënterende enquête: $6.5 \%$ wan de via de eigen huisarts ondervraagde patiënten heeft er bezwaar tegen dat een huisarts, die tijdens de vacantie de eigen huisarts zal vervangen, inzage zal krijgen in zijn/haar dossier. Bij patiènten, die tijdens de wacantie van hun eigen huisarts de waamemende huisarts consulteerden, lagen de zaken anders: in deze concrete situatie had slechts $3.5 \%$ van de ondervraagde patienten bezwaar tegen deze gang van zaken. De auteurs zijn van mening, dat door deze wijze van gegevensuitwisseling de beschikbaarheid en bereikbaarheid van de huisarts duidelijk verbetert en zien dit als een voordeel voor arts én patiênt. Zij achten het toelaatbaar, dat zij als geconsulteerde waamemende huisartsen inzage hebben in het dossier wan de patient die ze behandelen. Niet alle patiènten denken hier zo over. Hoe gaan we daar mee om? Een aantal algemene ethische en juridische yragen staat nog ter discussie.

\subsection{Inleiding}

Tijdens hun vacantie trekken solistisch werkende huisartsen meestal geen aparte waarnemer aan. Collega's uit de waarneemgroep waartoe zij behoren nemen de zorg voor hun patiënten over. De vervangende arts heeft meestal geen directe toegang tot het patiêntendossier (de 'groene kaart') van zijn collega. In veel gevallen blijven de waarnemingsconsulten beperkt tot éenmalige, korte en niet gecompliceerde ziektegevallen (hoest, lumbago, etc.), waarbij het ontbreken van de achterliggende patiëntgegevens geen handicap is. In andere gevallen is goede achtergrondinformatie wél nuttig en valak essentiè.l.

In beide gevallen (met en zonder achtergrond) komt het de vervangende zorg ten goede als de mogelijkheid tot het bereiken van de achtergrondgegevens aanwezig is. In de recente LHV-Nota "De Bereikbaarheid en Beschikbaarheid van de huisartsenzorg" "wordt gesteld dat 'gegevens over patienten, waarvan aannemelijk is dat ze relevant zijn, door de huisarts aan de waarnemer overgedragen dienen te worden.' De schrijvers van deze nota stellen tevens vast, dat 'het automatiseren van patiëntgegevens, die zonodig via een toegangscode voor de waarnemer on-line toegankelijk zijn, grote voordelen heeft'.

Privacy-bewaking en kosten-aspect worden ter discussie gesteld. Voorheen werd, om

Dit hoofdstuk is eerder gepubliceerd als: Hoppener $\mathrm{P}$, Rethans Jy, Vain de Winkel M. Op den Kamp M. De bereikbaarheid wan de "groene kaart" bij de waameming. Med Contact 1990; 45: 445-8. De bij dit artikel gepubliceerde juridische en ethische kanttekeningen zijn overgenomen in de appendix.

De cartoon op pag. 106 is van de hand van A. Hezemans (Wia Media, Heerlen). 


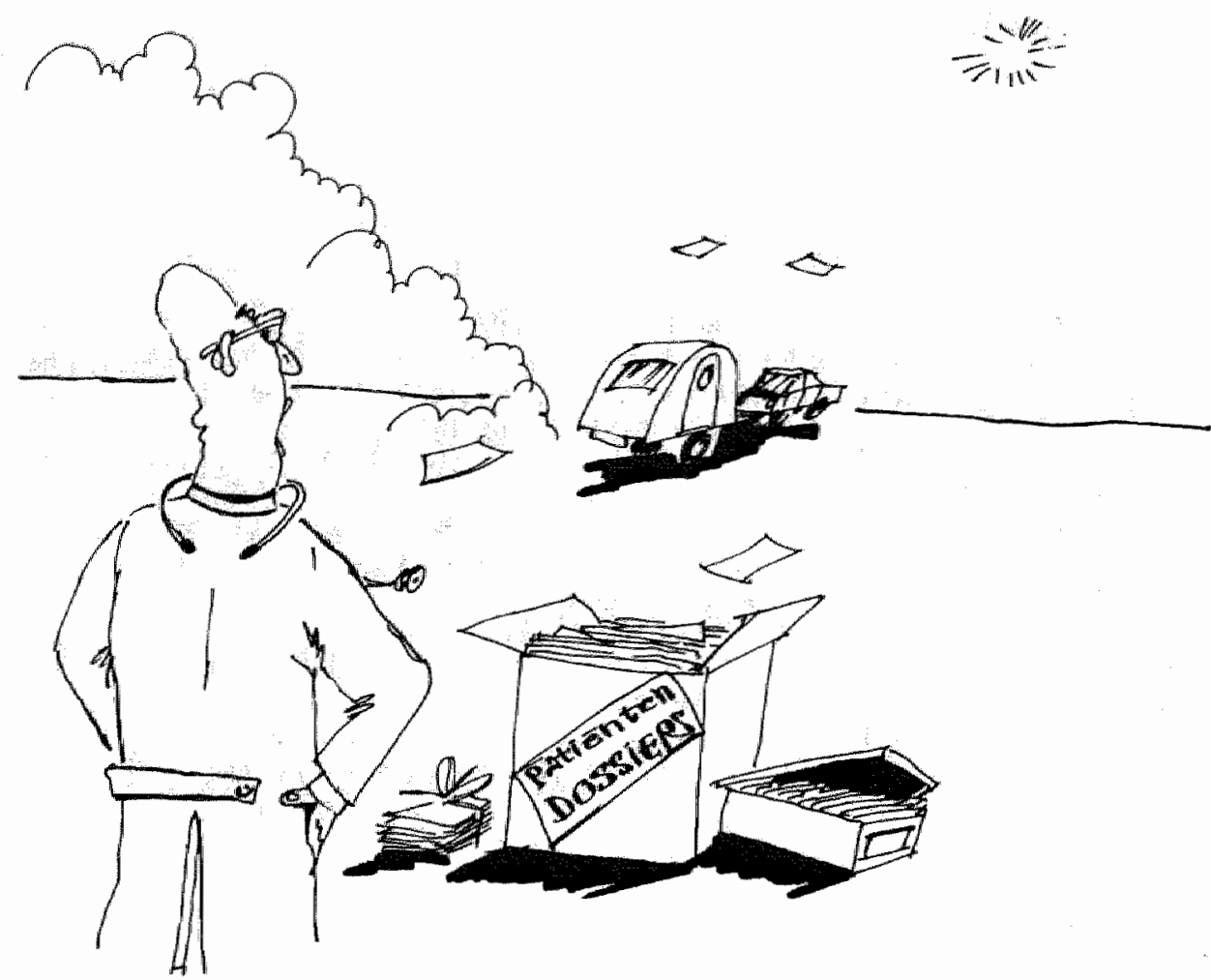

aan deze in de LHV-nota genoemde eis te kunnen voldoen, tijdens vacanties toegang tot de kaartenbak van de afwezige collega gerealiseerd door introductie bij de 'huis-bewaker" of door het tijdelijk beschikbaar stellen van een huissleutel van het praktijkpand. Meestal bleef het hierbij: het vérgaren van de vaak gewenste extra informatie kostte te veel tijd; de drempel was te hoog.

Nu kan de geautomatiseerde huisarts, wanneer hij op vacantie gaat, de 'volledige kaartenbak' aan zijn collega overhandigen: alle patiëntendossiers 'gedigitaliseerd' en vastgelegd op een data-tape die de afmeting heeft van een normaal cassettebandje. De waarnemer brengt deze op tape vastgelegde gegevens over naar het vaste geheugen (de harde schijf) wan zijn praktijkcomputer. Hierna heeft hij via enkele eenvoudige toetscommando"s inzage in alle dossiergegevens van de waarneempatiènten: direct en onmiddellijk. Hierbij wordt geen gebrwik gemaakt van de nu nog trage en moeilijk te beveiligen telefoonverbindingen.

Toen wij deze mogelijkheid konden realiseren tijdens de laatste vacantieperiode, werden reeds eerder ter discussie gestelde ${ }^{2}$ algemene ethische en juridische vragen actueel:

- Wat vinden de betrokken patiënten hiervan?

Is hierbij een verschil tussen patiënten bij wie het consult bij de waarnemende arts wél dan (nog) niet aan de orde is?

- Wordt op deze wijze niet ingebroken in de persoonlijke levenssfeer van de patiënt (privacy aspecten)?

- Wat zijn de juridische consequenties? 


\subsection{Methode}

Tijdens een vacantieperiode in 1989 werd een veldtest uitgevoerd in 2 praktijken in Heerlen, waar de solistisch werkende huisartsen beurtelings afwezig waren, en éen praktijk in Kerkrade. Het in deze praktijken gebrukte Huisarts Informatie Systeem "microHIS* maakt het mogelijk simultaan meerdere patientbestanden te raadplegen en te bewerken. De geautomatiseerde huisartsen kregen volgens de zojuist beschreven methode toegang tot de bestanden van de waameempraktijk. De collega die op vacantie ging leverde voór zijn vertrek een datatape af, die werd ingelezen in de computer van de waarnemende collega.

Om de mening van de patiênten te testen hebben we tijdens betreffende waameemperiode een korte orièterende enquête gehouden. Aan elke in de waarneming geziene patiënt van de collega die op vacantie was werd gevraagd of hij/zij bezwaar aantekende tegen het feit, dat de waarnemende huisartsen rechtstreeks inzage hadden in het dossier dat door de eigen huisarts was aangelegd (zie fig. 1). Tegelijkertijd werd aan een gelijk aantal eigen patiënten die het spreekuur bezochten dezelfde vraag in aangepaste vorm voorgelegd (zile fig. 2). De ingevulde enquêteformulteren konden gedeponeerd worden in een "stembus' die niet in het zicht stond van de arts of de assistente, zodat anonimiteit was gewaarborgd. De probleemstelling en de resultaten van deze studie werden voorgelegd aan 3 nationale experts op het gebied van gezondheidsrecht, ethiek en patiëntenrecht.

Figuur 10.1 Voorbeeld van een enquêteformulier voor de patiën" die de waarnemer consulteert.

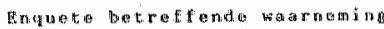

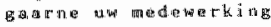

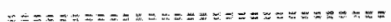

Vor engen hus

is enkel thek op was antio

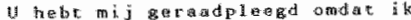

vasto warnemer ben vnow zijm

praktikile.

Dang $x$ i

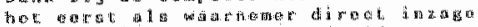

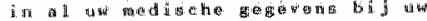

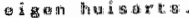

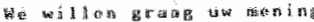

da $\begin{gathered}\text { a } \\ \text { roser hot }\end{gathered}$

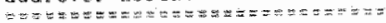

or 4 H

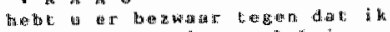

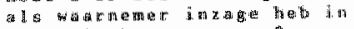

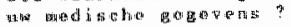

( ) j通

(1) nete

(f) nivet ilt nitet

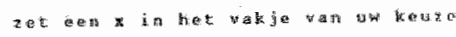

Figuur 10.2 Voorbeeld van een enquêtteformulier voor de 'eigen' patiènten.

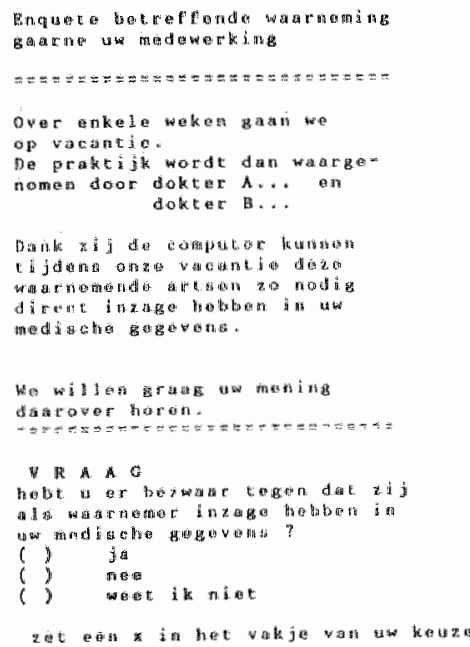




\subsection{Resultaten}

De untkomst van de opiniepeiling is weergegeven in de tabellen 10.1 en $10.2 .13 .3 \%$ van de eigen ondervraagde patienten heeft er bezwaar tegen dat een huisarts, die tijdens de vacantie de eigen huisarts zal vervangen, inzage zal krijgen in zijn/haar dossier. Van de patiënten, die tijdens de vacantie van hun eigen huisarts de waamemende huisarts consulteerden had slechts $6.5 \%$ van de ondervraagde patiènten bezwaar tegen deze gang van zaken ( $P=0,12$ bij tweezijdige chikwadraat-toets). Opvallend was dat zeer veel patiênten spontaan opmerkten, dat ze zeer blij waren met deze nieuwe ontwikkeling.

De opinies van de drie experts werden verkregen en zijn in de appendix van dit proefschrift opgenomen.

Tabel 10.1 Uitkomsten wan het opinie-onderzoek in twee praktijken in Heerlen ( $P R K I$ en $P R K 2)$ en én praktijk in Kerkrade (PRK3), die waarneemt voor PRK4. W = patiënten wit de waarneempraktijk; $Z=$ patiënten uil de "eigen" praktijk.

\begin{tabular}{|c|c|c|c|c|c|c|c|c|c|}
\hline \multirow{3}{*}{$\begin{array}{l}\text { Inzage } \\
\text { patiantentossier }\end{array}$} & \multicolumn{4}{|c|}{ Hearlen } & \multicolumn{4}{|c|}{ Kerkradie } & \multirow[t]{3}{*}{ Totaall } \\
\hline & \multicolumn{2}{|c|}{ PRK1 } & \multicolumn{2}{|c|}{ PRK2 } & \multicolumn{2}{|c|}{ PRK3: } & \multicolumn{2}{|c|}{ PRK4 } & \\
\hline & $w$ & $\mathbf{z}$ & $\bar{w}$ & $\bar{z}$ & $\bar{w}$ & $z$ & $w$ & $z$ & \\
\hline Bezwaar & 3 & 5 & 1 & 3 & 2 & 4 & & & 18 \\
\hline Geen bezwaar & 40 & 37 & 27 & 24 & 19 & 17 & & & 164 \\
\hline Geen mening & 1 & 2 & 0 & 1 & 0 & 0 & & & 4 \\
\hline Totaal & 44 & 44 & 28 & 28 & 21 & 21 & & & 186 \\
\hline
\end{tabular}

Tabel 10.2 Overzicht van resultaten patiëntenenquête.

\begin{tabular}{lrcc}
\hline Inzage patientdossier & $w$ & $z$ & Totaal \\
\hline Bezwaar & 6 & 12 & 18 \\
Goen bezwatar & 86 & 78 & 164 \\
Totaal & 92 & 90 & 182 \\
\hline
\end{tabular}

$P=0,12$ (chi-kwadraattoets voor ongepaarde waamemingen, tweezijdige toetsing).

\subsection{Beschouwing en conclusie}

Bij een twee jaar geleden verricht onderzoek in de geautomatiseerde praktijk wan twee wan de auteurs kwam naar voren, dat 30\% van de patiënten zich zorgen maakte over de privacy-aspecten, omdat het medisch dossier werd vastgelegd in de computer. ${ }^{3}$ In de hier beschreven veldtest werd een zeer specifieke vraag gesteld: "hebt $U$ er bezwaar tegen dat een andere arts, die waameemt voor uw huisarts, inzage krijgt in uw medische gegevens?". 
Nu bleek slechts $10 \%$ ( 18 van de 182 ondervraagde partiènten) aan te geven dat men hiertegen bezwat had. Mogelijk speelt de algemene en overwegend positieve maatschappelijke acceptatie van de computer hierbij een rol. Patienten, die tijdens de vacantie van bun eigen huisarts de waarnemende huisarts consulteerden, betrekken wellicht de voordelen van deze gegevensuitwisseling sterker bij hun oordeel: in deze concrete situatie had slechts $6.5 \%$ van de ondervraagde patiënten bezwar tegen deze gang wan zaken, terwijl bij ondervraging door de eigen huisarts dit percentage $13.3 \%$ bedroeg. Belangrijker dan dit -overigens statistisch niet significante- verschil is echter dat in beide gevallen de overgrote meerderheid van de ondervraagden geen bezwaar heeft.

De uitkomst van dit opinie- onderzoek roept niettemin enkele vragen op: de stem van de democratische meerderheid mag hier zeker niet alleen beslissend zijn, maar jedere "niet accoord' verklaring weegt zwaar.

De auteurs zijn van mening, dat door deze wijze van gegevensuitwisseling de beschikbaarheid en bereikbaarheid van de huisarts duidelijk verbetert en zien dit als een voordeel voor arts én patiënt. $\mathrm{Zij}$ achten het toelaatbaar, dat zij als geconsulteerde waarnemende huisartsen inzage hebben in het dossier van de patiënt die ze behandelen.

Niet alle patiënten denken hier zo over.

De huidige hardware en software maken een ideale bereikbaarheid van patièntendossiers tijdens vacantiewaarnemingen technisch mogelijk. Er bestaat geen twijfel over dat dit soort ontwikkelingen, die nu nog slechts in enkele praktijken zijn uitgetest, over een aantal jaren door veel huisartsen gerealiseerd kunnen worden. Waarnemende huisartsen, die op deze wijze patiëntbestanden uitwisselen voor exclusief gebruik tijdens de warrneemperiode, zullen mee moeten denken over de medisch-ethische en juridische aspecten hiervan, ook indien zij deze gang van zaken toelaatbaar achten. Want nog steeds heeft een aanzienlijk aantal patiënten (ca 5-15\%) hier een duidelijk andere mening over.

Per 1 juli 1989 is de eerste fase van de WET Persoonsregistraties ingegaan. ${ }^{4}$ We hebben nog tijd om na te denken over de toelaatbaarheid van alleriei praktijkvoering-ondersteunende faciliteiten, die de voortschrijdende automatiseringstechniek binnen ons bereik brengt. Om een aanzet te geven tot verdere discussie en commentaar door de lezers van Medisch Contact ${ }^{5}$ werd in dat blad aan het originele artikel het commentaar van een aantal inhoudsdeskundigen, die om een reactie was gevraagd, toegevoegd.

Deze kanttekeningen zijn opgenomen in de appendix bij dit proefschrift.

Deze deskundigen onderstrepen nog eens het belang van een goed privacyreglement en van duidelijke voorlichting aan de patiënten betreffende de gang van zaken bij waarneming.

Uit de reacties van de gevraagde inhoudsdeskundigen blijkt ook, dat aan de volgende vraagpunten nog de nodige aandacht besteed moet worden:

- het uitlenen van datatapes aan waarnemende artsen brengt extra risico's met zich mee voor de privacy van de patiènt.

- er zou een onderscheid gemaakt moeten worden tussen artsen die als 'vervanger "optreden en artsen die als ' waarnemer' optreden.

- indien een huisarts als waamemer optreedt is het waak niet nodig, en ook niet wettelijk vereist, dat hij beschikt over de gegevens van de patiënt die hem/haar consulteert.

- een aantal patiênten zal het niet op prijs stellen dat de waarnemer inzage heeft in hun gegevens. 
- de sten van de patienten die bezwaar maken tegen de beschreven uitwisseling van informatie tussen de eigen huisarts en de als wamemer optredende huisarts moet gehoord worden.

- vanuit het Landelijk patienten/consumenten platform wordt gesteld dat in principe elke patient vooraf toestemming zal moeten geven voor het overdragen van zijn/haar gegevens an de waarnemende huisarts.

\section{Literatuur}

1 Landelijke Huisartsen Vereniging. De bereikbaarheid en beschikbaarheid van de huisantsenzorg. Utrecht 1989.

2 Cranendonk E. Automatisering van de artsenpraktijk en het recht van de patiènt op priwacy. MC 1985; 40:1561-63.

3 Rethans JJ, Hoppener $\mathrm{P}$, Wolfs $\mathrm{G}$, Diederiks I. Do personal computers make doctors less personall? Br Med J 1988, 296:1 14648.

4 Doppegieter RMS Palientendossiers en de Wet persoonsregistraties. Consequenties voor individuele artsen en instellingen van gezondheidszorg. MC 1989; 44:1379-83.

5 Höppener $P$, Rethans JJ, Winkel M van de, OpdenKamp M. De bereikbaarheid van de 'groene kaart' bij waameming. MC 1990; 45: 445-8. 


\section{Beschouwing en conclusies}

'Het is te hopen dat helder denken, dat een woonwarde is voor het electronisch verwerken wan gegevens, het klinisch beshitwomingsproces zal kumen verbettren." (H.R.Wulf, Principes van kliwisch denken en handelen)

In de voorafgaande hoofdstukken is een antal gegevens verzameld die in dit hoofdstuk worden gegroepeerd op onderwerp en worden geêvalueerd. Het verzamelde materiaal biedt voldoende ondersteuning voor de in hoofdstuk 1 geformuleerde stellingen: 'Automatisering van de huisartspraktijk vergroot de mogelijkheden voor wetenschappelijk onderzoek en woegt dastmee een nieuwe dimensie toe aan het werk van de huisarts' en 'De steeds verder voortschrijdende integratie van de conputer in de huisartspraktijk zal de komende jaren de praktijkvoering efficienter maken en de kwaliteit van het werk van de huisarts verbeteren". In dit hoofdstuk worden deze conclusies nog verder vitgewerkt. Er wordt een overzicht gegeven van toepassingen wan de automatisering in do huisartspraktijk.

\subsection{Huisarts en computer}

De in hoofdstuk 2 beschreven ontwikkeling van de automatisering in de Nederlandse huisartspraktijk heeft ertoe geleid dat er nu professionele software beschikbaar is voor de huisarts die wil automatiseren. De centraie begeleiding van dit proces door de Werkgroep Coördinatie Informatie Automatisering (WCIA) speelde hierbij een belangrijke rol.

De eisen wararan Huisarts Informatie Systemen (HIS) moeten voldoen zijn duidelijk geformuleerd. De momenteel beschikbare hardware is betrouwbaar en snel. De personal computers worden nog steeds verder geperfectioneerd.

Via cursussen, congressen en een stroom van publicaties zijn steeds meer huisartsen 'computerrijp' gemaakt.

De aankondiging van het zogenaamde 'Plan Dekker," door het kabinet Lubbers-II heeft veel huisartsen definitief over de streep getrokken, omdat in de toekomst het in te voeren "gemengde honorarium- systeem" nogal wat extra financiëel-administratieve inspanning zou gaan vragen. Dit argument lijkt inmiddels achterhaald, want het nieuwe ka* binet Lubbers III komt in 1990 met een totaal ander beleidsvoorstel: "de Themanota Stelselherziening Zorgsector'.

Naar schatting maakt $35 \%$ van de Nederlandse huisartsen momenteel bij de praktijkvoering gebruik van een computer. Dit percentage neemt snel toe. Toekomstige technische ontwikkelingen zullen deze trend nog versterken: gegevens uitwisseling met apothekers, diagnostische centra en ziekenhuizen, de beschikbaarheild van grote databestanden op CD-ROM, de medische chipkaart en huisartsvriendelijke beslissings-ondersteunende software.

Het ziet er naar uit dat de jaren van de inmiddels vergrijsde 'Groene Kaart' zijn geteld. Steeds meer huisartsen zijn rijp voor de voigende stap in de praktijkautomatisering: het vastleggen van de medische patiëntgegevens in de computer. 


\subsection{Huisarts en wetensehap}

Een analyse van 105 huisurtsgeneeskundige onderzockversilagen (zie hoofdstuk 3) toont aan, dat computers de laatste 10 jaar een belangrijke rol hebben gespeeld bij huisartsgeneeskundig onderzoek. Het betreft hier vrijwel altijd centraal opgestelde computers (mini of mainframe) waarin de onderioekdata worden opgeslagen en bewerkt. Vaker dan valt op te maken uit de publicaties wordt bij het verzamelen van literatuur een computersearch verricht. Zelden wordt vermeld, dat bif statistische bewerkingen van onderzoekdata gebruk gemaakt is van computer-programma's die voor dit doel zijn ontwikkeld.

Dataverzameling an de bron, in de huisartspraktijk zelf, blijft tot nu toe het stiefkind van de automatisering. Huisartsen en onderzoekers registreren de onderzoekgegevens nog steeds handmatig op een apart formulier of op de 'Groene Kaart'. Vaak worden deze gegevens dan in tweede instantie ingebracht in een centrale computer en daar verder bewerkt.

De noeste vlijt waarmee ook nu nog een aantal huisartsen door de kaartenbakken ploegt om feiten te verzamelen voor de wetenschap roept grote bewondering op. En ook verwondering. 23

\subsection{Huisarts, wetenschap en computer}

De meeste grote huisartsgeneeskundige registratiesystemen in Nederland registreren de te verzamelen items nog op formulieren.

Deze (soms al gecodeerde) formulieren worden op een centraal punt verzameld en daar in een databestand opgeslagen en bewerkt.

Het geïntegreerde gebruik van de computer in de huisartspraktijk, met als onderdeel hiervan de geautomatiseerde medische registratie, begint de laatste jaren geleidelijk op gang te komen. Bij de opzet van het Registratienet Huisartspraktijken van de Rijksuniversiteit Limburg (RNH) is zeer bewust voor deze aanpak gekozen. De automatisering van de deelnemende huisartspraktijken wordt door het RNH gezien als een hulpmiddel voor huisarts en onderzoeker. De achtergrondvariabelen en de probleemlijsten van de patiẻnten in de computer zijn direct beschikbaar voor de praktijkvoering en voor onderzoek.

In de standaard 'Medische Verslaglegging': yan her Nederlands Huisartsen Genootschap wordt gesteld, dat het ('leesbaar') vastleggen van deze gegevens een onderdeel is van de normale taak van de huisarts. ${ }^{4}$ De computer ondersteunt praktijkvoering en verslaglegging volgens deze standaard en bevordert hiermee de kwaliteit van het huisartsgeneeskundig handelen. De tegelijkertijd door de computer beschikbaar gestelde en toegankelijk gemaakte onderzoekgegevens zijn een "natuurlijk bijproduct" van de geautomatiseerde medische registratie.

In hoofdstuk 6 wordt beschrewen hoe dit systeem werkt. De hoofdstukken 7 en 8 laten niet alleen zien hoe in de praktijk onderzoek kan worden uitgevoerd, maar laten vooral ook zien 'dat het werkt". 


\subsection{Methodollogische vragen}

Het in de hoofdstukken 7 en 8 besproken explorerende en toetsende onderzoek noept een aantal methodologische vragen op, die niet definitief in dit proefschrift beantwoord zullen worden, maar in een latere publicatie vanuit het RNH. Het is niet goed mogelijk om in deze fase van bestandsopbouw, in aamulling op de vergelijkende studies met betrekking tot het RNH en de regionale kankerregistratie, al exacte cijfers te geven over de volledigheid en de betrouwbaarheid van de uit RNH-praktijken afkomstige gegevens, die voor onderzoek zijn gebruikt. De eerste indruk is positief.

In hoofdstuk 5 wordt beschreven welke andere vormen van toetsing nu al binnen het RNH-project zijn gerealiseerd:

- geautomatiseerde contrôle van de verzamelde data op volledigheid, consistentie en betrouwbaarheid.

- consensus-bijeenkomsten en intercollegiale toetsing.

- feedback vanuit de centrale databank over inconsistenties, fouten en omissies.

Omdat het er nar uitziet dat de computer van de huisarts steeds vaker zal worden ingeschakeld bij wetenschappelijk onderzoek, is het belangrijk om op korte termijn meer onderzoek te doen naar de methodologische aspecten. Dit onderzoek zou zich met name moeten richten op de volgende aspecten:

\section{a. de betrouwbaarheid en validiteit van het meetinstrument}

- de foutbestendigheid en betrouwbaarheid van de gebruikte hardware en software.

- de bruikbaarheid en trefzekerheid van het gehanteende codestelsel (ICPC).

- de factor 'huisarts en assistente', waarbij valt te denken aan menselijke fouten, vergissingen en omissies onder invloed van te grote werkdruk en vermoeidheid.

- de betrouwbaarheid van de geautomatiseerde gegevensoverdracht naar de centrale computer.

- de betrouwbaarheid van de centrale gegevensopslag en van de centraal voor databewerking toegepaste software.

\section{b. de representativiteit van de gegevens en bias?}

- de invloed van inter-arts en intra-arts variabiliteit bij het stellen van een diagnose en het coderen van problemen.

- het optreden van storende selectiemechanismen, bijwoorbeeld onderregistratie van allcoholisme of van psychische aandoeningen door een registrerende arts" die hier zelf problemen mee heeft.

- bestandsvervuiling die bijvoorbeeld optreedt wanneer vertrekkende patiënten niet regelmatig gearchiveerd worden en uit het bestand worden verwijderd.

- het niet correct coderen volgens afgesproken criteria.

- bij observationeel onderzoek dat gebruik maakt van in de praktijkcomputer opgeslagen gegevens zal men ook altijd bedacht moeten zijn op 'confounding by indication'. Bij interventieonderzoek kan men aan de bron al gebruik maken van de compuiter om te randomiseren en/of te stratificeren. 
c. de 'schinzekerheid' bij automatische gegevenswerwerking.

- vaak wordt er ten onrechte van uit gegaan dat onderzoekgegevens betrouwbaar zijn omdat ze zijn opgeslagen in de computer. Helaas is dit niet altijd het geval.

\section{d. de "methodologie van de privacy"}

- bij wetenschappelijk onderzoek zal vaak een zeer zorgvuldige koers gevaren moeten worden om bij het verzamelen van onderzoekgegevens niet in te breken in de persoonlijke levenssfeer van de patient.

\subsection{Patiènt en computer}

In de hoofdstukken 9 en 10 wordt eindelijk ook eens gekeken naar de patiënt: wat vindt die ervan? Uit het daar beschreven onderzoek wordt duidelijk, dat bij patiënten juist de bescherming van de persoonlijke levenssfeer (priwacy) een belangrijke rol speelt. De meeste parienten accepteren het gebruik van de computer in de huisartspraktijk: het contact met de huisarts wordt er niet ininder persoonlijk door. Wel is duidelijk dat veel aandacht besteed zal moeten worden aan de bescherming van de privacy.

Er blijft nog een antal juridische en ethische vragen bestaan rond het gebruik wan me-

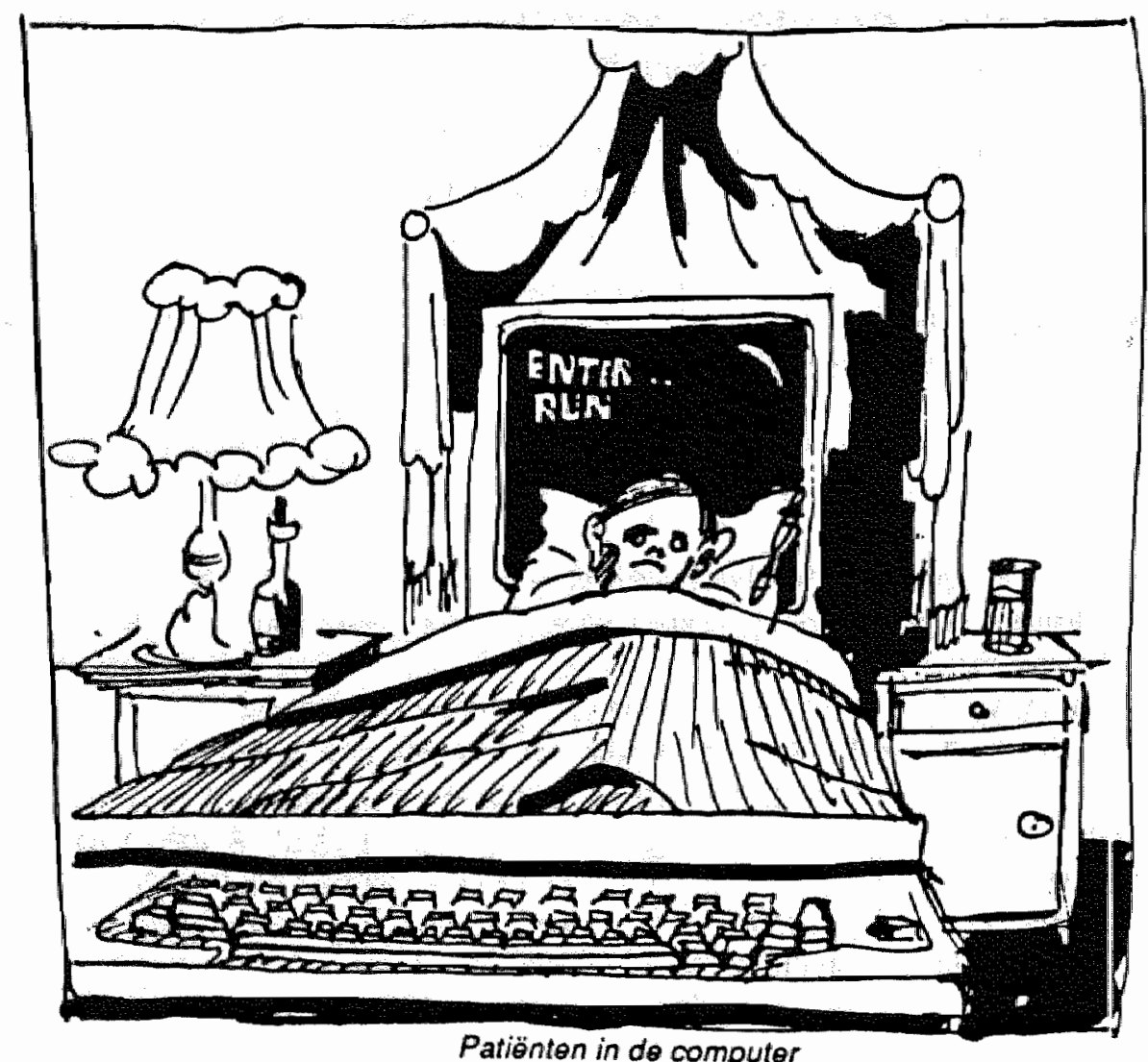


dische bestanden in de huisartspraktijk, obk wanneer deze slechts worden geraadpleegd voor directe hulpverlening door huisarts of waarnemer. De Wet Persoonsregistraties van 28 december 1988 vermeldt in artikel 11 , dat "ten behoeve van wetenschappelijk onderzoek gegevens aan derden verstrekt mogen worden voor zover de persoonlijke levenssfeer wan de geregistreerde daardoor niet onevenredig wordt geschaad" 5 Vertegenwoordigers van de patièntenverenigingen wijzen er op dat deze wet pas voor grote delen van de gezondheids-dienstverlening van betekenis is, indien alle houders van persoonsregistraties werken met een reglement. Hierin moeten de rechten en plichten van alle bij de registratie betrokken personen zo expliciet mogelijk beschreven zijn. ${ }^{6}$

Zoals reeds eerder werd opgemerkt is het van groot belang dat huisartsgeneeskundige onderzoekers bij het verzamelen van patiëntgebonden gegevens een zeer zorgvuldige koers varen, waarbij de bescherming van de persoonlijke levenssfeer van de betrokken patiënten goed in het oog wordt gehouden. Alleen dan zijn patiënigebonden huisartsgeneeskundig onderzoek en bescherming van de privacy van de patiënt goed met elkaar te verenigen.

\subsection{Conclusies}

In de voorafgaande hoofdstukken zijn een aantal gegevens verzameld die leiden tot de volgende conclusies.

\section{Automatisering is een belangrijke stap vooruit}

omdat hierdoor de perifere huisarts kan beschikken over een effectief en in de praktijk gemakkelijk te hanteren instrument, waarmee hij/zij de medische patientgegevens overzichtelijker kan registreren en sneller kan raadplegen dan voorheen mogelijk was. De huisarts kan hierdloor zijn/haar spilfunctie als belangrijke 'informatiedrager' en beheerder van basale medische gegevens beter waarmaken.

Geautomatiseerde registratie van patiëntgebonden gegevens in de huisartspraktijk vergroot de mogelijkheden voor het verrichten wan wetenschappelijk onderzoek

De in een aantal praktijkcomputers opgeslagen gecodeerde probleemlijsten vormen nu al een ideale basis voor het opbouwen van cen huisartsgeneeskundig steekproefbestand. De op deze wijze prospectief vastgelegde patiëntgebonden gegevens zijn een goed toegankelijke bron voor huisartsgeneeskundig onderzoek (zie tabel 11.1).

Wanneer de huisarts beschikt over een praktijkcomputer dan wordt het aantrekkelijk om vanuit eigen specifieke deskundigheid of interesse huisartsgeneeskundig onderzoek te doen. Wanneer hij/zij dit doet in teamverband met universitaire onderzoekers dan is er aan beide kanten veel winst te behalen.

De komende jaren zullen belangrijke veranderingen brengen in de beroepsuitoefening van de huisarts. De computer zal hierbij zeker een grote rol spelen.

Kwaliteitsbewaking en onderlinge toetsing staan sterk in de belangstelling. Indien de huisartsen in de komende jaren hier zelf geen sluitende afspraken over maken dan zal de overheid hier wellicht een instrument voor ontwikkelen en dwingende eisen opleggen. 
Tabel 1L. Toepassingen van de computer in de huisantspratetis.

1. Praktijkvoering

- facturering en boekhouding

- apotheek-administratie

- tekstverwerking

2. Praktische zorgverlening

- 'Groene Kaart'-functie

- receptuur medicatiebewaking

- rationele diagnostiek via bewaking van werkafspraken en protocollen

- telecommunicatie lapotheek, ziekenhuis, waarnemend huisarts)

- medische databank

- beslissingsondersteuning (expert systeem)

3. Wetenschappelijk onderzoek

- peilstation-functie

- monitoring

- transversaal onderzoek

- patiẻnt-contrôle onderzoek

- longitudinaal onderzoek/cohort onderzoek

- interventie onderzoek

- postmarketing surveillance

4. Toetsing

- toetsing van eigen handelen

- onderlinge toetsing

- kwaliteitsbewaking (onder meer aan de hand van standaarden)

5. Onderwijs

- ondersteuning met actuele praktijkgegevens

- computerondersteunde nascholing

6. Beleidsondersteuning

- bron voor gegevens met betrekking tot morbiditeit en verrichtingen

7. Preventie

- oproepsysteem voor bepaalde categoriến patiënten

- signalering van verhoogde incidenties, bijvoorbeeld in relatie tot $m$ ilieu-invioeden

In een aantal praktijken is aangetoond dat automatisering van de huisartspraktijk de reflectie op het eigen functioneren (toetsing en kwaliteitsbewaking) ondersteunt (hoofdstuk 5). Steeds vaker werken huisartsen in groepsverband of dragen als solist werkende huisartsen een deel van hun taak over aan een part-time werkende huisarts of wamemer. De in een praktijkcomputer vastgelegde gegevens zijn vrijwel altijd gemakkelijker te le- 
zen en sneller op te zoeken dan de gegevens op een "Groene Kaart". Dit is vooral van belang indien meerdere artsen, die al of niet partime werkzaam zjn, de verantwoordelijkheid voor de behandeling van én patient delen en dus ook goed informeerd dienen te zijn over deze patiènt.

\section{De computer ondersteunt het onderwijs in de huisartsgeneeskwnde.}

Vaak ontbreken actuele gegevens uit de praktijk met name op het gebted van cassuistiek en epidemiologische informatie. Deze gegevens zijn nu direct beschikbaar in de computers van geautomatiseerde praktijken. Ook kunnen zij worden opgevraagd uit centrale gegevensbanken, die gevoed worden door deze bronnen. Bovendien kan de praktijkcomputer ook nog een rol spelen bij de actieve nascholing van de huisarts.

De overheid zoekt nalar een instrument voor vervolmaking en verdieping van het stelsel van epidemiologische informatie-systemen in de gezondheidszorg. Het ziet er natar uit dat steeds meer huisartsen over zullen gaan tot geordende geautomatiseerde vastlegging van patientgebonden gegevens (zie hoofdstuk 4). Deze huisartsen kunnen dan een rol spelen bij de "systematische vergaring van morbiditeitsgegevens aan de bron". Ze verzamelen 'automatisch' de epidemiologische informatie, die de locale en centrale overheden nodig hebben bij een verantwoorde planning van de gezondheidszorg.

Preventie van ziekten behoort tot het takenpakket van de huisarts. Een goede registratie van medische gegevens, met name van verrichte screening ten aanzien van risicofactoren en het beloop, is hier een voorwaardle voor. De computer kan de huisarts effectief ondersteunen bij het uitvoeren van deze preventieve taak. In het buitenland bestaat al de nodige ervaring wat betreft deze toepassingsmogelijkheid van de praktijkcomputer. ${ }^{7-10}$

Het leggen van relaties tussen gezondheidsklachten en milieu-invloeden was tot nu toe vrijwel niet mogelijk, omdat epidemiologische gegevens over regio en wijk meestal niet of zeer beperkt beschikbaar waren. Een continue en betrouwbare probleemregistratie, die in een groot aantal geautomatiseerde huisartspraktijken platsvindt, zou in combinatie met expositie-gegevens een instrument kunnen zijn voor het signaleren van eventueel bestaande correlaties tussen gezondheidsproblemen en nadelige milieufaktoren. Het is zeker de moeite waard om de mogelijkheden van het instrument 'huisartsen-automatisering' voor dit doel nader te onderzoeken.

In het begin van dit proefschrift werden twee stellingen geformuleerd betreffende de invloed van de praktijkautomatisering op wetenschappelijk onderzoek in de huisartspraktijk, de praktijkvoering van de huisarts en de kwaliteit van het werk van de huisarts:

- 'Automatisering van de medische registratie vergroot de mogelijkheden voor wetenschappelijk onderzoek in de huisartspraktijk en voegt daarmee een nieuwe dimensie toevoegt aan het werk van de huisarts.

- 'De steeds verder voortschrijdende integratie van de computer in de huisartspraktijk zal de komende jaren de praktijkvoering efficiënter maken en de kwaliteit van het werk van de huisarts verbeteren."

Resumerend menen wij te kunnen stellen, het bovenstaande in aanmerking nemend, dat deze stellingen in ruime mate onderbouwd worden door het in dit proefschrift angedragen materiaal en door de gesignaleerde ontwikkelingen elders. 


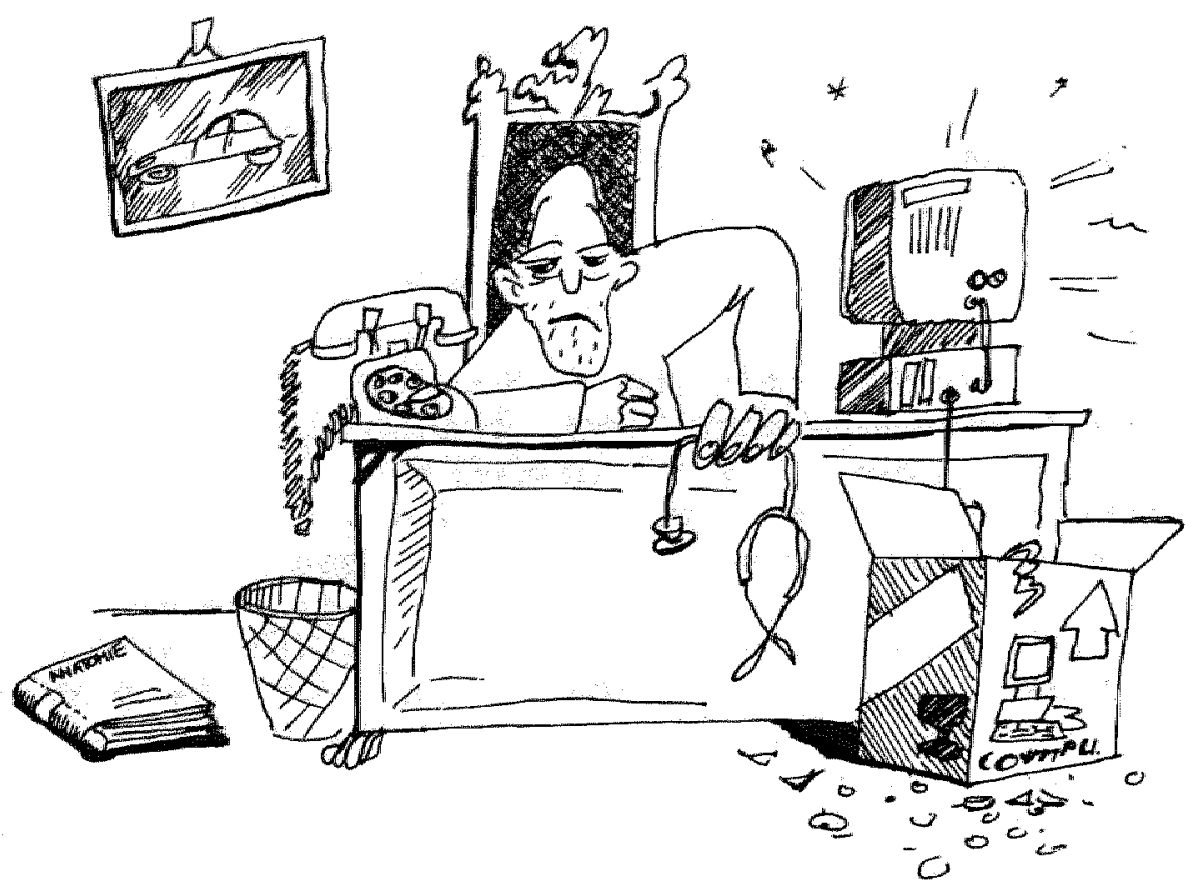

stethoscoop

telefoon

auto

groene kaart

computerl

\section{Literatuur}

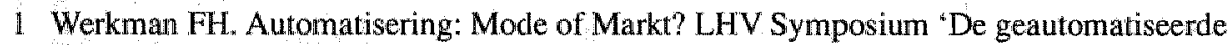
huisarts in het Dekker-tijdperk' Ede 1989 (samenvatting lezing).

2 Walma EP, Boukes FS, Prins A, Does E van der. Diureticagebruik door 65-plussers in een huisartspraktijk. Huisarts Wet 1989; 32:326-8.

3 Haan M de. Indicatoren voor CARA bij kinderen. Een transversaal onderzoek onder 6-11 jarigen in vijf Nederlandse huisartsprakilijken. Huisarts Wet 1989; 32: 334-7.

4 Nederlands Huisartsen Genootschap. Medische Verslaglegging. Standaard Huisarts Wet 1990; 33: 114-17.

5 Korthals Altes F. (Minister van Justitie). Wet van 28 december 1988, houdende regels ter bescherming van de persoonlijke levenssfeer in verband met persoonsregistraties (Wet Persoonsregistraties). Staatsblad 1988; 665:1-13

6 Wilk J van der. De verandering voor de patiënt/verzekerde als gevolg van de Wet persoonsregistraties. SIG-symposium "De gevolgen van de wet Persoonsregistraties voor de gezondheidszorg": 1989 .

7 Graaf $F$ de. Privacy en gezondheidsgegevens: een model van regelgeving. TMI 1988; 17: PALGA-Katem 7.9.

8 Boomla K, Jewll T, Robson J, Self J, Taylor J, Fitzpatrick S, Ridley M. Developing a computerized preventive program. Practitioner 1987; 231: 1440.

9 Block B, Brennan JA. Automated health surveillance. Fam med 1988; 20: 377-80.

10 Mc Dowell I, Newell C, Rosser W. A randomized trial of computerized reminders for blood pressure screening in primary care. Med Care. 1989; 27: 297-305.

11 MeDowell I, Newell c, Rosser $W_{*}$ Computerized reminders to encourage cervical screening in fanily practice. J Fam Pract 1989; $28: 420-4$ 


\section{Samenvatting}

Stethoscoop, telefoon, auto en groene kaart zijn technische en administratieve hulpmiddelen bij de praktijkvoering van de huisarts. De computer lijkt een plaats in te gaan nemen in deze rij van onmisbare instrumenten. De laatste jaren gaan steeds meer huisartsen over tot het gebruik van de computer als hulpmiddel bij de financièadministratieve praktijkvoering. Een praktijkcomputer die voorzien is van een goed Huisarts Informatie Systeem (HIS) maakt het praktisch uitwoerbaar om de inmiddels al vergrijzende 'groene kaart' te vervangen en systematisch over te gian tot probleemgeoriënteerde medische verslaglegging.

Dit proefschrift onderstreept dat automatisering van de medische registratie de mogelijkheden voor wetenschappelijk onderzoek in de huisartspraktijk vergroot en daarmee een nieuwe dimensie toevoegt aan het werk van de huisarts. Tevens wordt de acceptatie van de computer in de huisartspraktijk bestudeerd en wordt een aantal uitspraken gedaan over de mogelijke gevolgen die de acceptatie en integratie van de computer in de huisartspraktijk zal hebben voor de beroepsuitoefening van de huisarts.

De automatisering van de Nederlandse huisartspraktijken is in 1979 aarzelend op gang gekomen en zet nu pas door: een goede aanleiding om een historisch overzicht te geven van deze laatste 10 jaar, en een beschrijving te geven van de huildige stand van zaken en de verwachtingen voor de jaren negentig. Aan de hand van een literatuuronderzoek wordt nagegaan, in hoeverre automatisering in het verleden een rol van betekenis heeft gespeeld bij patiëntgebonden huisartsgeneeskundig onderzoek. Het blijkt dat de computer reeds vaak wordt gebruikt voor centrale gegevensopslag en soms ook ondersteuning biedt bij literatuuronderzoek en bij de statistische bewerking van onderzoekgegevens. Geautomatiseerde data-verzameling aan de basis, in de huisartspraktijk, blijkt nog geen rol te spelen. Er wordt een uilspraak gedaan over de veronderstelde meerwarde van de automatisering van de huisartspraktijk bij een anantal typisch huisartsgeneeskundige onderzoekmethoden.

Herna volgt een bespreking van negen bestaande huisartsgeneeskundige registratiesystemen in Nederland. Er blijken zeer grote verschillen te bestaan in doelstelling en werkwijze. Bij enkele van de beschreven projecten zal de praktijkcomputer van de huisarts een belangrijke rol gaan spelen bij het vastleggen van de onderzoekgegevens. Bij één project is dit al in ruime mate het geval: door het Registratienet huisartspraktijken van de Rijksuniversiteit Limburg (RNH), wordt een centraal steekproefbestand opgebouwd van geanonimiseerde patiën-tachtergrondvariabelen en probleemlijsten betreffende circa 80.000 patienten. Dit steekproefbestand moet vooral gezien worden als een index, die verwijst naar de individuele patiëntregistratie in de computer van de huisarts.

De methode van registratie bij het RNH en de wijze van dataverzameling worden 
besproken. Tevens wordt ingegaan op de specifieke automatiseringsaspecten van dit project en wordt duidelijk gemaakt welke rol de verzamelde gegevens spelen op de verschillende niveau's van onderzoek.

De bij het RNH gerealiseerde geautomatiseerde verslaglegging en registratie worden getest in 2 onderzoeken. Bij het eerste onderzoek werd de meerwaarde van deze verslaglegging bij kwaliteitsbewaking en toetsing getest 'in de praktijk' en positief beoordeeld. Als voorbeeld werd een onderzoek uitgevoerd naar de regulatie van de bloedsuiker bij patiënten met diabetes mellitus type II. Bij het tweede onderzoek werd gekeken naar de betrou wbaarheid en volledigheid van de gegevens, die door de huisartsen zijn vastgelegd in de computer. Gekozen werd voor een vergelijkend onderzoek van de registratie van de diagnose kanker bij het RNH en bij de regionale kankerregistratie van het Integraal kankercentrum Limburg (IKL). Dit proefonderzoek bij twee registratiesystemen in de opbouwfase leverde als voorlopige conclusie op, dat beide registratiesytemen niet meer dan 5\% van de kankergevallen gemist hadden. Het lijkt erop dat RNH en IKL elkaar kunnen aanvullen en de 'blinde wlekken' in elkaars registraties zichtbaar kunnen maken.

Hierna wordt de aandacht gericht op de patiënten in de geautomatiseerde huisartspraktijken. De resultaten van een enquête naar de acceptatie van de praktijkcomputer door de patiênten worden vermeld. Het bleek dat men weinig moeite heeft met het gebruik van een computer in de spreekkamer. Wel liet $30 \%$ van de patiënten weten, dat ze zich zorgen maakten over de privacy-aspecten. Een tweede onderzoek gaat hier verder op in: patiënten geven hun mening over het onderling uitwisselen van data-tapes met patiëntgebonden gegevens tussen huisartsen, die elkaars praktijk waarnemen tijdens de vacantie. Het blijkt dat 5 tot $15 \%$ van de ondervraagde patiënten hier bezwaar tegen heeft. Een aantal algemene ethische en juridische vragen staat nog ter discussie.

Tot slot wordt geconcludeerd dat het in dit proefschrift verzamelde materiaal voldoende ondersteuning biedt voor de volgende uitspraken:

- Automatisering van de medische registratie vergroot de mogelijkheden voor wetenschappelijk onderzoek in de huisartspraktijk en voegt daarmee een nieuwe dimensie toevoegt aan het werk van de huisarts.

- 'De steeds verder voortschrijdende integratie van de computer in de huisartspraktijk zal de komende jaren de praktijkvoering efficiènter maken en de kwaliteit van het werk van de huisarts verbeteren."

In de conclusies worden deze stellingen nog verder uitgewerkt. Enkele methodologische aspecten van de geautomatiseerde dataverzameling in de huisartspraktijk en de gegevensopslag in een centraal computerbestand worden nog benoemd, waama een overzicht volgt van een aantal voor de hand liggende toepassingen van de automatisering in de huisartspraktijk en de door dit 'instrument' op te bouwen databestanden. 


\section{Summary}

The stethoscope, the telephone, the car and the card index file are technical and administrative tools in a General Practitioner"s practice. The computer seems to be about to claim its place in this list of essential instruments. Increasingly, GPs are adopting the computer as an aid in the financial and administrative management of their practices. A practice computer equipped with an adequate General Practice Informarion System makes it feasible to replace the by now rather outdated card index fille by a systematic, problem-oriented medical registration.

It is the purpose of this thesis to show that automation of medical registration increases the opportunities for medical research in general practice and thus adds a new dimension to the GP's work. In addition, a number of statements are made on the consequences which adopting and integrating the computer into general practice may have for the way in which a GP exercises his profession.

The automation of Dutch general practices started rather hesitantly in 1979 and is only now gaining momentum, which makes this a good moment to reflect on the developments over the past ten years, on the present situation and on prospects for the 1990s. A literature study was made to examine the extent to which automation has in the past contributed to patient-related research in general practice. It was found that the computer is already in frequent use for centralized data storage, and sometimes also as an aid to literature research and the statistical processing of research data. Automated data collection was not found to play an important role at the primary level, i.e. in the general practice. The supposed added value of the automated general practice in a number of typical general practice research methods is discussed.

This is followed by a review of 9 existing general practice registration systems in the Netherlands, which were found to differ greatly in their aims and methods. Two of the projects will make elaborate use of the GP's practice computer in storing the research data. This is already happening in one project: since 1988, the General Practice Registration Network (RNH) at the University of Limburg has been building up a centralized sample file of anonymized patient background variables and problem lists based on ca. 80,000 patients. This sample file must first of all be regarded as an index which refers to the individual patient registration in the GP's computer.

The methods of registration and data collection in the RNH are discussed, as are the specific automation aspects of this project. It is shown how the data collected are used at the various levels of research.

The automated filing and registration systems developed at RNH were tested in two studies. The first of these evaluated, 'in practice', the added value of this filing system in quality control and assessment, which was found to be positive. By way of example, a study was made of the regulation of blood sugar levels in patients with Type Il diabetes 
mellitus. The second sudy evaluated the reliability and completeness of the data stored in the computer by the general practitioner. We opted for a comparative study of the registration of the diagnosis of cancer at the $\mathrm{RNH}$ and at the district cancer registration service of the Limburg Integrated Cancer Centre (IKL). This pilot sudy of two registration systems in their initial stages yielded the preliminary conclusion that both systems missed $5 \%$ of cancer cases. It appears that the RNH and IKL systems can complement each other and reveal the "blind spots" in each other's registrations.

The thesis then pays attention to the patients in the automated general practices. Results are presented of a questionnaire survey of the degree of acceptance of the practice computer by patients. Patients were found not to resent the use of a computer in the consulting room, all though $30 \%$ said that they were worried about privacy aspects. A second study elaborated on this aspect, and asked patients to give their opinion on the exchange of data tapes containing patient-related data between GPs who substitute for colleagues during the holidays. At least $3.5 \%$, and possibly as many as $10 \%$ of the patients interviewed were found to object to this. Clearly, a number of general ethical and legal issues still await further discussion.

Finally, it is concluded that the data presented in this thesis lend sufficient support to the following statements:

- "Automation of medical registration increases the possibilities for scientific research in general practice, and thus adds a new dimension to the GP"s work."

- "Over the next few years, the continuing integration of the computer into the general practice will render practice management more efficient and improve the quality of the GP's work.'

These conclusions are further elaborated on. Some methodological aspects of automated data collection in general practice and of data storage in a central database are discussed. Finally, a survey is presented of a number of obvious applications of automation in general practice, as well as the data files that have been compiled with the help of this "instrument". 


\section{Zusammenfassung}

Stethoskop, Telefon, Auto und Karteikarte sind technische und administrative Hilfsmittel in der Hausarztpraxis. Der Computer scheint auf dem Wege zu sein, in dieser Reihe untentbehrlicher Instrumente einen Platz einzunehmen. In den letzten Jahren gehen immer mehr Hausärzte dazu über, den Computer als Hilfsmittel bei der finanziell-administrativen Verwaltung ihrer Praxis zu benutzen. Ein Praxiscomputer, der mit einem guten Hausarztinformationssystem (HIS) ausgestattet ist, ermóglicht es, die inzwischen schon veraltende Karteikarte zu ersetzen und planmäBig zu problemorientierter medizinischer Berichterstattung überzugehen.

Diese Dissertation will zeigen, daß Automatisierung der medizinischen Datenerfassung die Möglichkeiten für wissenschaftliche Forschung in der Hausarztpraxis vergröBert und damit die Arbeit des Hausarztes um eine neue Dimension bereichert. Zugleich werden einige Thesen aufgestellt über die möglichen Folgen, die das Akzeptieren und Integrieren des Computers in die Hausarztpraxis für die Austibung des Hausarztberufes haben werden.

Die Automatisierung der niederländischen Hausarztpraxis ist 1979 zögernd in Gang gekommen und setzt sich jetzt erst durch: ein guter Anlaß, einen historischen Uberblick zu geben über diese letzten 10 Jahre, eine Bestandsaufnahme der heutigen Situation und eine Zusammenfassung der Erwartungen für die neunziger Jahre.

Anhand der Fachliteratur wird der Frage nachgegangen, inwieweit Automatisierung in der Vergangenheit eine wesentliche Rolle bei patientgebundener hausarztmedizinischer Forschung gespielt hat. Es zeigt sich, daß der Computer schon oft für zentrale Datenspeicherung benutzt wird und manchmal auch beim Studium der Fachliteratur und bei der statistischen Auswertung von Untersuchungsergebnissen Hilfe leistet.

Es stellt sich heraus, daB die automatisierte Datenerfassung an der Basis, in der Hausarztpraxis, noch keine Rolle spielt. Zu dem vorasgsetzten Mehrwert der Automatisierung der Hausartztpraxis bei einer Anzahil von typisch hausarztmedizinischen Untersuchungsmethoden wird Stellung genommen.

Darauf folgt eine Besprechung von 9 in den Niederlanden angewandten hausarztmedizinischen Registriersystemen. Zielsetzung und Arbeitsweise erweisen sich als stark unterschiedlich. Bei 2 Projekten wird der Praxiscomputer des Hausarztes bei der Festlegung der Untersuchungsbefunde eine wesentliche Rolle spielen. Bei einem Project ist dies schon der Fall: Seit 1988 baut das RNH (Registratienet Huisartspraktijken, d.h. hausartztmedizinische Datenerfassungssitelle) der Reichsuniversităt Limburg eine zentrale Stichprobendatei von anonymisierten Patienthintergrundwariablen und Problemlisten auf, die etwa 80.000 Patienten erfaßt. Diese Stichprobendatei muß vor allen Dingen als Index betrachtet werden, der auf die individuelle Patientendatei im Computer des Hausartztes verweist. 
Die Regighriemethode des RNH und die Att und Weise der Datenerfassung werden erortert. Auch wird auf die spezifischen Automatisierungsaspekte dieses Projektes näher eingegangen und wird Klargemachi, welche Rolle die erfaBten Daten in den einzelnen Untersuchurigsphasen spielem.

Die beim RNH durchgefuhrte automatisiente Berichterstattung und Datenerfassung wurden in 2 Untersuchungen erprobt. Bei der ersten Untersuchung wurde der Mehrwert. solcher Berichterstattung im Hinblick auf Qualitätsiberwachung 'in der Praxis' getestet und positiv bewertet. Als Beispiel wurde die Regulierung des Blutzuckers bei Patienten mit insulinunabhängigem Diabetes mellitus untersucht. Bei der zweiten Untersuchung ging es um die Zuveriässigkeit und Vollständigkeit der von Hausarzten im Computer gespeicherten Daten. Die Wahl fiel auf eine vergleichende Untersuchung der Registrierung der Krebsdiagnose, wie sie vom RNH und von der regionalen Krebsregistrierstelle des IKL, des Integralen Krebszentrums Limburg, vorgenommen wurde. Diese Probeuntersuchung bei 2 Registriersystemen im Aufbau ergab als vorlăufiges Fazit, daB beiden Systemen $5 \%$ der Krebsfälle entgangen waren. Es sieht danach aus, daß das RNH und das IKL sich gegenseitig ergänzen und die 'blinden Flecken" im System des jeweils anderen aufdecken können.

Danach werden die Patienten in der automatisierten Hausarztpraxis ins Auge gefaBt. Die Ergebnisse einer Umfrage darüber, ob und wie die Patienten den Praxiscomputer akzeptieren, werden erwähnt. Es zeigte sich, daß bei ihnen die Benutzung eines Praxiscomputers im Sprechzimmer kaum auf wiederstand stöBt. Wohl gaben 30\% der Patienten zu erkennen, sie machten sich Sorgen wegen des Datenschutzes. Einen zweite Untersuchung geht näher darauf ein: Patienten geben ihre Meinung über den Austausch von Datentapes mit patientgebundenen Daten durch Hausảrzte, die sich in der Urlaubszeit gegenseitig vertreten. Es zeigt sich, daß mit Sicherheit 3.5\% womöglich sogar $10 \%$, der befragten Patienten Bedenken dagegen haben. Eine Anzahl allgemeiner ethischer und juristischer Fragen stehen noch deutlich zur Diskussion.

Als SchluBfolgerung ergibt sich, daß das in dieser Dissertation gesammelte Material in ausreichendem Maße zu folgenden Thesen berechtigt:

- 'Automatisierung der medizinischen Datenerfassung erweitert die Möglichkeiten für wissenschaftliche Forschung in der Hausarztpraxis und bereichert damit die Arbeit des Hausarztes um einen neue Dimension."

- "Die immer weiter fortschreitende Integration des Computers in die Hausarztpraxis wird in den kormmenden Jahren die Praxisausubung effizienter machen und die Qualithit der Arbeit des Hausarztes verbessern."

Diese SchluBfolgerungen werden noch weiter ausgewertet. Einige methodologische Aspekte der automatisierten Datenerfassung in der Hausarztpraxis und der Datenspeicherung in einer Zentraldatei werden diskutiert. Dem folgt ein Überblick über eine Anzahl naheliegender Anwendungen der Automatisierung in der Hausarztpraxis und über die durch dieses Instrument aufgebauten Datenbestănde. 


\section{Résumé}

Le stéthoscope, le téléphone, la voiture et la 'carte verte' sons les outils techniques et administratifs de soutien dans la pratique du médicin généraliste. L'ordinateur semble devenir un outil important parmi cette série d'instruments indispensables.

L'emploi de l'ordinateur prend une place de plus en plus importante dans la pratique financière et administrative. Il permet de remplacer la carte verte déjà démodée pour le medecin disposant d'une programmation (H.I.S.) d'information médicale systérnatique pour le mise à jour du dossier médical.

Cette thèse de doctorat veut démontrer que l'automatisation des données médicales favorise les possibilités de recherches scientifiques dans la practise médicale générale en ajoutant ainsi une nouvelle dimension dans le travail du médecin. De plus en plus certaines interprétations sont émises quant aux conséquences possibles de l'aceptation et de l'intégration de l'ordinateur dans la pratique médicale courante.

Dès lors cette thèse est un argument valable pour donner un aperçu historique de dix ans de pratique et propose une perspective d'application pour la prochaine décennie.

Par l'examen de la litérature la qquestion se pose dans quelle messure l'automatisation a joué un rôle important dans la recherche appliquée de la médecine générale. Il en ressort que l'ordinateur a êté fréquemment employé pour rassembler les données centrales et parfois comme outil adjuvant de recherche litétaire et de travail statistique des travail des données d'investigation. Il ne semble pas qu'il aie joué un rôle dans le rassemblement des données de base dans la pratique médicale. L'on se prononce sur la plus-value hypothêque de l'automatisation de certaines méthodiques de recherche typique dans la médecine générale.

Neuf systèmes de régistration de médecine générale existant aux Pays-Bas ont été examinés. De grandes différences ont été constatées dans la méthode de travail et de l'objectif recherché.

Dans đeux projets l'ordinateur du médecin généraliste joue un rôle important dans la régistration des données de recherche. Dans le premier projet un sondage a progressivement rassemblé en 1988 des données cliniques anonymes d'environ 80.000 malades. Grâce au Réseau de Régistration de Médecine Générale de ل"Université de Maastricht (R.N.H.) les variables d'information de base et les listes à problèmes des malades ont été recueillies. Ce sondage doit être interprèté comme un indice de régistration individuelle de l'ordinateur du médecin génêraliste.

La méthode de régistration et la façon de rassembler les données par le R.N.H. sont discutées. De plus les aspects spécifiques de l'automatisation de projet sont analysés ainsi que le rôle que jouent les données aux différents niveaux de la recherche.

La régistration et l'information réalisées par le R.N.H. ont été controlées par deux tests. Par le premier la plus-value de cette informatique a été controlée en pratique sur la 
qualité du montitoring. II a té jugé positif. Par exemple: la régulation de la glycémie chez les diabétiques type II a été vérifiée. Par le second test la fiabilité et l'intégrite des donnés consignées dans l'ordinateur ont été confirmées. On a opté pour une recherche comparée de la régistration du diagnostic de cancer du R.N.H. el du Centre régional de Régistration de Cancer du Limbourg (I.K.L.). Cette recherche a démontré provisoirement que لes deux systèmes de régistration ont manqué le diagnotic de cancer dans $5 \%$ des cas la phase primaire de l'́laboration. Pourtant le R.N.H. et IIK.L. sêmblent se compléter et les parties cachées sont démasquées.

$L^{*}$ attention des malades a été attiree sur les pratiques medicales automatisees. Considérant les patients appartenant aux pratiques médicales automatisées, une enquête révele les résultats suivants: en consultation, la présence de 1 ordinateur pose peu de problèmes. Néanmoins $30 \%$ des malades sont soucleux quant a l'atteinte du secret médical. Ce probleme aété approfondi par un second examen. A savoir, l'opinion que se font les patients de l'échange de leurs donnees aux médecins remplaçants en cas d'absence: $3,5 \%$ des patients sont en désaccord et la probabilité de $10 \%$ n'est pas exclue. Quelques questions juridiques et éthiques sont mises en discussion.

Finalement les donnees recueillies dans cette etide appuient suffisament les thèses suivantes:

- 'L'automatisation de la régistration médicale favorise les possibilités de recherches scientifiques dans la pratique médicale et y ajoute une dimension nouvelle au travail du médecin généraliste.

- L'intégration progressive de l'ordinateur dans la pratique produira pour les années à suivre un redement de plus en plus êlevé et donnera lieu a une amélioration qualitative de la prestation médicale'.

En plus les conclusions ont subi une mise au point ultérieure. Quelques aspects méthodoligiques de l'informatique des données rassemblées sont discutés ainsi que le receuil des données dans la programmation d'un ordinateur central.

Un apercu montre des applications évidentes de l'automatisation dans la pratique médicale ainsi que des données de programmation édifiées par cet "instrument". 


\section{Appendix}

\section{Ethische kanttekeningen in zake privacy \\ Commentaar van Prof. Dr. Paul Sporken}

De zwijgplicht ten aanzien van gegevens, die tot de intiemsfeer van patiënten behoren, is even oud als de geneeskunde zelf. Achtergrond vormt de overtuiging, dat ieder mens recht heeft op zijn persoonlijke intimiteit; deze mag niet zonder zijn toestemming doorbroken worden. De zekerheid, dat deze gegevens door zijn arts als toevertrouwd geheim beschouwd worden, is de reden waarom hij ze met een gerust hart aan zijn arts kan mededelen.

In de gezondheidszorg hebben ook op dit punt veranderingen plaatsgevonden. Het beroepsgeheim is geen zaak meer tussen individuele arts en patiënt. Patiënten zijn er aan gewend geraakt en accoord gegaan (sommigen slechts contre coeur!) met een uitbreiding van het beroepsgeheim in die zin, dat bijvoorbeeld team-leden kennis nemen van bedoelde privacygegevens. Uiteraard geldt ook voor hen het beroepsgeheim, maar de ervaring leert dat dit helaas niet altijd woor honderd procent lukt.

Naast het bewaren van het beroepsgeheim kan ook de registratie en het gebruik van eerder verkregen informatie van belang zijn voor de behandeling van de patiënt. Vanzelfsprekend dienen de geregistreerde gegevens op een zodanige wijze gebruikt en bewaard te worden dat het beroepsgeheim niet in het gedrang komt. Als een belangenconflict zou ontstaan tussen beroepsgeheim en een (in sommige gevallen) betere behandeling door een waarnemend arts, dan weegt mijns inziens het beroepsgeheim het zwaarst.

Voorzichtigheid eist om in de patiëntenregistratie alleen de privégegevens op te nemen, die voor de verdere behandeling van daadwerkelijk belang zijn. Tegen de achtergrond van het spanningsveld tussen bescherming van privacy enerzijds en registratie en gebruik van patiëntengegevens anderzijds, dienen de volgende kanttekeningen over de uitwisseling van data-tapes.

Heel in het algemeen kan mijns inziens gesteld worden, dat het gebruik hiervan door een waarnemend collega-huisarts geen principiële bezwaren oproept, mits de privacy van de patiënten volledig gewaarborgd blijft. De indruk bestaat dat bij het uitlenen van datatapes de risico's voor de privacy van patienten groter zijn dan bij de gebruikelijke 'groene kaart' van de huisarts. Bedoeld is niet, dat computer-krakèrs op de loer liggen voor deze gegevens, maar dat alle samengepakte, geautomatiseerde informatie gemakkelijker bereikbaar wordt en dus speciale veiligheidsmaatregelen vereist. Het ter beschikking stellen van data-tapes aan een waarnemend collega lijkt mijderhalve slechts verantwoord mits de risico's, die zich hierbij kunnen voordoen, opgespoord en door geèigende maatregelen bestreden worden.

Daarbij nog een laatste opmerking. De auteurs vermelden weliswaar, dat een aantal pa- 
zijn: leg patiènten expliciet de bedoelde vraag voor. Deze zijn dan in de gelegenheid schriftelijk hun toestemming hiervoor te geven ( art.12 Wet Persoonsregistraties).

Zolang de híerboven beschreven gang van zaken zich nog in het experimentele stadium bevindt, is het desalniettemin de plicht van de huisarts om in het kader van een zorgvuldige overdracht zijn waamemer te informeren over die patienten, die waarschijnlijk tijdens de waarneming een beroep op hem zullen doen. Hieraan is ook uiting gegeven in de ontwerp-Modelregeling arts-ptient (KNMG-LP/CP).

Een laatste opmerking mijnerzijds betreft de mogelijkheid, die de deelnemende artsen als positief hebben ervaren, "om bij elkaar in de "kaart te kijken" en zo elkaar te kunnen toetsen'.

Ik ben van mening dat intercollegiale toetsing niet slechts wenselijk, maar ook noodzakelijk is. Maar ik versta onder intercollegiale toetsing wel iets meer dan het slechts bij elkaar in de kaart kunnen kijken. 
theriten bezwaren heeft en dat de stem var de democratische meerderheid niet alleen-beslissend mag zijn. Zuj zeggen whter niet wat met de stem van de minderheid gedaan wordt. Het lijkt mij toe, dat thun stem niet alleen gehoord moet worden, maar dat er ook gehoor aan gegeven moet worden!

\section{Juridische kanttekeningen}

\section{Commentaar wan Prof.Mr.Dr.H.D.C.Roscam Abbing}

Wij kunnen er gewoeglijk van uilt gaan dat de dossiervoering bij de huisarts - zeker met de toenemende automatisering, de situatie geschetst door Höppener e.a. is hiervan een voorbeeld - valt onder de Wet Persoonsregistraties. En uit dien hoofde (zeer waarschijnlijk, immers afhankelijk van nog op te stellen nadere regels) reglements- en meldingsplichtig is (bij Registratiekamer) en afdoende beveiligd moet zijn. Voorts zal, indien en zodra de in 1987 als voor-ontwerp bekend gemaakte wettelijke regeling met betrekking tot rechten wan de patiẻnt (zgn: indiwiduele behandelingsovereenkomst) wordt ingevoerd, ook deze van belang zijn. Hoe dan ook zullen de gegevens van de patient op dusdanige wijze moeten worden beheerd, dat geen ongeoorloofde verstrekking aan derden plaatsvindt en dat de gegevens niet voor onbevoegden toegankelijk zijn.

\section{Toegankelijkheid gegevens voor waarnemer}

Behoudens met toestemming wan de patient of uit hoofde van een wettelijk voorschrift zijn de medische gegevens niet toegankelijk voor anderen dan bij de behandeling betrokken personen (en uiteraard de patient zelf). Anders is sprake van ongeoorloofde derdenverstrekking. (het zogenaamde conflict van plichten wordt hier buiten beschouwing gelaten vanwege het exceptionele karakter daarvan). De toestemming van de patiènt zal zeker altijd expliciet verkregen moeten worden indien het betreft gegevensverstrekking aan andere dan direkt bij zijn behandeling betrokken personen.

Tot welke categorie behoort nu de waarnemer? Iedere weldenkende patient zal zich realiseren dat zijn huisarts een warnemer heeft en dat deze - indien en voorzover nodig - inzage in zijn medische gegevens moet kunnen hebben. De huisarts zal er goed aan doen zijn patienten bij het eerste contact globaal van zijn waarnemingsregeling in kennis te stellen en dakarbij tot uitdrukking te brengen dat de waarnemer, indien de patient hem nodig heeft, in principe toegang heeft tot diens gegevens. Hiermee wordt de patiënt de mogelijkheid geboden daartegen bezwaar te maken. Hijzal dan wel gewezen moeten worden op de eventuele konsekwenties van zijn bezwaar.

\section{Privacyreglement}

De voortschrijdende techniek maakt een adekwaat daarop toegesneden systeem voor bescherming van de privacy van de patiènt noodzakelijk. Uiteraard moeten veiligheidsmaatregelen worden getroffen, de zogenaamde fysieke bescherming van gegevensbestanden. Bovendien zal de huisarts een privacyreglement moeten opstellen, waarin onder meer het doel, de werking, de rechten van de patiënt, toegang tot en gebruik van de gegevens moeten worden geregeld. Daarin zal bijwoorbeeld ook worden opgenomen wie de gebruiker is van de persoonsregistratie. Naast de huisarts zal de waarnemer in een con- 
crete situatie de gegevens moeten kumnen raadplegen en informatie moeten kunnen toevoegen, zodat ook de waamemer als gebruiker is aan te merken. De Nationale Raad voor de Volksgezondheid heeft in 1988 een modelreglement ontworpen voor individuele beroepsbeoefenaren (advies gebruik van privacyreglementen, publicatie 19), terwijl voorts uiteraard de beroepsorganisatie hierbij een taak heeft.

\section{Voorlichting patient}

Een hulpmiddel bij het informeren van de patient vormt, ter aanvulling van mondeling te verstrekken informatie, een patiëntenfolder.

In ziekenhuizen zijn deze al vrij algemeen. In de huisartsenpraktijken minder. Juist met het oog op de hierwoor behandelende problematiek zou het zinvol zijn het gebruik van zo'n folder in de hüsartsenpraktijk te introduceren. Daarin kan dan worden uiteengezet hoe de gegevens van de patient worden beschermd, hoe het met inzage daarvan zit, hoe het privacyreglement eruit ziet en hoe de waarnemingsregelingen zijn, mede in relatie tot de privacyproblematiek. Het SIG heeft een tekstvoorstel voor zo'n folder voor ziekenhuizen gemaakt. Dit verdient alleen maar navolging ten behoeve wan de huisartsenpraktijk.

\section{Kanttekeningen vanuit het Landelijk patiënten/consumenten Platform}

Commentaar van J.wan der Wilk, directeur.

De ontwikkelingen, zoals door Höppener e.a. beschreven, zijn wanuit het oogpunt van verbetering van de kwaliteit van de dienstverlening door de huisarts toe te juichen: de waarnemer kan het door de door hem waargenomen collega ingeslagen traject snel en adequaat vervolgen en behoeft niet vanuit een nul-positie te vertrekken. De achterstand van de waarnemer blijft beperkt tot kennis over de patiënt die niet in een of andere vorm op de 'groene kaart' is geregistreerd.

Vanuit het oogpunt van bescherming van de persoonlijke levenssfeer van de patiènt kunen bij de beschreven ontwikkelingen echter kanttekeningen geplaatst worden. In de relatie patiënt-arts ontstaan gegevens over de patiënt, die als vertrouwelijk gekarakteriseerd moeten worden. De patiënt moet er op kunnen vertrouwen dat deze gegewens in beginsel niet aan derden worden verstrekt. Het is ook artikel 10 van onze grondwet dat dit recht op bescherming van de persoonlijke levenssfeer verankert. Alleen bij of krachtens wet kunnen hierop uitzonderingen worden gemaakt. In dit verband is van belang artikel 11 lid 1 Wet Persoonsregistraties. Hierin wordt bepaald dat uit een persoonsregistratie slechts gegevens aan een derde worden verstrekt *... voor zover zulks voortvloeit uit het doel van de registratie, wordt vereist ingevolge een wettelijk voorschrift of geschiedt met toestemming van de geregistreerde". Hoewel het nog onduidelijk is of handmatig aange legde persoonsregistratie nu wel of niet binnen de reikwijdte van de wet vallen - naar mijn mening wèl- is dit met geautomatiseerde registraties zeker het geval. En hiervan is in casu sprake. De vraag is dan of werstrekking van de gegevens voortvloeit uit het doel van de registratie.

lk ben van mening dat het doel van een door een huisarts aangelegde pesoonsregistratie, namelijk het mogelijk maken wan een goede hulpverlening, niet de verstrekking hiervan 
aun een derde triet zich meebrengt. In het andere geval zouden zonder de toestemming van de patient diens gegevens te alle tijde aan de behandelaars kunnen worden doorgegeven. Evenmin is er een wettelijk voorschift dat tot verstrekking van de gegevens aan de waarnemer verplicht. Met andere woorden: toestemming van de patiènt is een vereiste. In mijn visie zal het Voorste: van Wet inzake de geneeskundige behandelingsovereenkomst, zoals althans de betreffende tekst thans luidt, bij inwerkingtreding hierin geen verandering brengen. Mer de in art. $1653 \mathrm{~L}$ lid 2 genoemde vervanger van de hulpverlener aan wie gegevens mogen worden verstrekt zonder de

toestemming van de patient, wordt naar mijn mening een ander bedoeld dan diens warnemer.

Er is sprake wan werwanging indien de oorspronkelijke hulpwertener eventueel zelf had kunnen komen, maar dit niet doet De hulpverlening door de vervanger vind in die situatie plaats op basis van dezelfde overeenkomst die gold en geldt voor de relatie tussen de patient en de oorspronkelijke hulpverlener (vervangen is hulppersoon).

Er is sprake van waameming indien de hulpverlener niet kấn komen en daartoe contractucel ook nooit gehouden kan zijn. In zo'n situatie sluit de patient een aparte overeenkomst met de waarnemer, op basis waarvan hij de waamemer naar beste weten dient te informeren. Doch deze "informatieplicht" van de patiënt vloeit niet voort uit de overeenkomst met de waargenomen huisarts.

lk ben van mening dat dit met name vanuit het patiëntenperspectief een zeer belangrijk uitgangspunt is. Automatisering van patientendossiers leidt ongetwijfeld tot meer uniformering, maar niet tot minder gevoelige gegevens.

Niet alleen over de gezondheid van de patiënt, maar ook over diens persoonlijke omstandigheden kunnen zeer gevoelige gegevens zijn opgeslagen. Gegevens die in de vertrouwensrelatie tussen de patiënt en de huisarts zijn ontstaan. De patiënt moet daarom ook zelf kunnen bepalen of al deze gegevens voor een waarnemer beschikbaar komen. Het kont nogal eens voor dat patiënten vanwege slechte ervaringen met een huisarts, overstappen op een ander.

Ik kan mij zeer wel indenken dat alleen al in zo'n situatie de patiènt het niet op prijs zou stelleen als zijn oorspronkelijke huisarts over zijn gegevens kan beschikken. Maar er zijin voldoende andere situaties denkbaar waarin dit ook van toepassing is. (bv. de huisarts is een kennis van patiènt).

Gelet op bovenstande, heb ik dan ook moeite met de in Heerlen en in Kerkrade uitgevoerde weldtest. Als ik het bovenstaande artikel goed begrijp is pas tijdens de test de patiênten de vraag voorgelegd of zij bezwaar hadden tegen het feit dat de waarnemende huisarts directe inzage in het dossier had, dat door hun eigen huisarts was aangelegd.

In de eerste plaats had een vratag van soortgelijke strekking vooraf gesteld moeten worden. In de tweede plaats had het niet moeten gaan om 'geen bezwaar', maar om 'toestemming'. Gelet op de resultaten van de onder patienten gehouden enquete was het dan mogelijk geweest - technisch kan dit geen bezwaar opleveren - om de gegevens van de patienten, die niet accoord waren gegaan, uit te zonderen.

Omdat $i k$, zoals reeds gesteld, het belang inzie van directe inzage in het patientenbestand door de waarnemer, zou mijn advies aan huisartsen die hiertoe willen overgaan, 


\section{Curriculum vitae}

Paul Höppener werd op 24 december 1937 geboren te Roermond. In 1955 behaalde hij het eindexamen gymnasium bêta aan het Bîsschoppelijk College aldaar, waarna hij geneeskunde studeerde aan de Katholieke Universiteit te Nijmegen. Na het artsexamen in 1962 was hij een jaar als assistent interne geneeskunde verbonden aan het ziekenhuis 'Ope Dei' te Woerden (Dr. R.G.A. van Wayjen).

Hierna werkte hij vijf jaar als tropenarts in het Katra ziekenhuis te Mandla M.P. in India. Na een episode van 9 maanden als assistent in opleiding tot cardioloog in het academisch ziekenhuis te Groningen (Prof. Dr. J. Nieveen) vestigde hij zich in 1970 als solistisch werkend huisarts in Heerlen, waar hij nog steeds als zodanig werkzaam is.

In 1980 werd hij lid van de werkgroep 'Huisarts en Computer' van het Nederlands Huisartsen Genootschap, in 1983 maakte hij deel uit van het ontwikkelteam bij het RIVOG-HIS-project en in 1985 was hij mede-oprichter van de gebruikersvereniging ORGHIS.

Vanaf 1977 is hij als huisarts-opleider verbonden aan de Rijksuniversiteit Limburg. Vanaf 1988 is hij daar tevens partime $(0,3)$ werkzaam als 'toegevoegd onderzoeker' en coördinator van het Registratienet Huisartspraktijken. 